2. To: (Receiving organization)

Distribution

5. Proj./Prog./Dept./Div.:

Waste Feed Delivery Program

8. Originator Remarks:

For information and distribution.
3. Fron: (originating Organization)

Tank Waste Retrieva]

6. Design Authority/ Design Agent/Cog. Engr.:

R. D. Potter

11. Receiver Remarks: 11A. Design Baseline Document? [] Yes [X] No

Page 1 of $\frac{1}{164}$

î. Design Baseline Doankent?

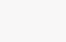

\begin{tabular}{|l|l|}
\hline & \\
\hline
\end{tabular}

4. Related EDT No.:

7. Purchase order

Order No.:

N/A

9. Equip./Component No.:

$\mathrm{N} / \mathrm{A}$

10. System/Bldg./Facility:

$\mathrm{N} / \mathrm{A}$

12. Major Assm. Dwg. No.:

$N / A$

13. Permit/Permit Application No.: $N / A$

14. Required Response Date:

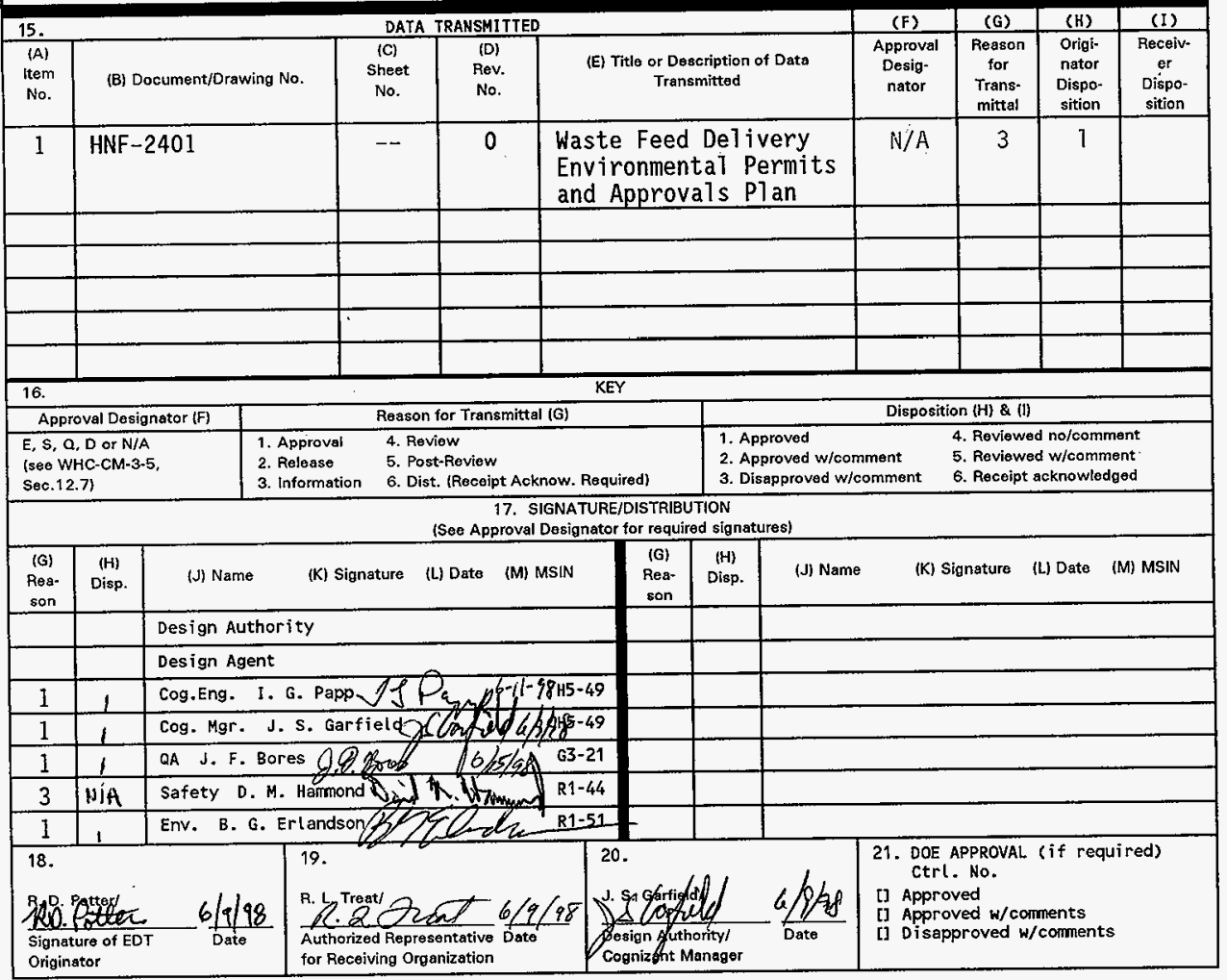




\section{Waste Feed Delivery Environmental Permits and Approvals Plan}

I. G. Papp, R. D. Potter, and R. L. Treat

Lockheed Mart in Hanford Corporation, Richland, WA 99352

U.S. Department of Energy Contract DE-AC06-96RL13200

EDT/ECN: 608764

Org Code: 73600

B\&R Code: EW3130010
UC: 721

Charge Code: D2D61

Total Pages: $-104-\bar{a} 101$

Key Words: environmental permits, waste feed delivery

Abstract: This document describes the range of environmental actions, including required permits and other agency approvals, that may affect waste feed delivery activities in the Hanford Site's Tank Waste

Remediation System. This document outlines alternative approaches to satisfying applicable environmental standards, and describes selected strategies for acquiring permits and other approvals needed for waste feed delivery to proceed.

TRADEMARK DISCLAIMER. Reference herein to any specific comercial product, process, or service by trade name, trademark, manufacturer, or otherwise, does not necessarily constitute or imply its endorsement, recormendation, or favoring by the United States Government or any agency thereof or its contractors or subcontractors.

Printed in the United States of America. To obtain copies of this document, contact: Document Control Services, P.O. Box 950, Mailstop H6-08, Richland WA 99352, Phone (509) 372-2420; Fax (509) 376-4989.
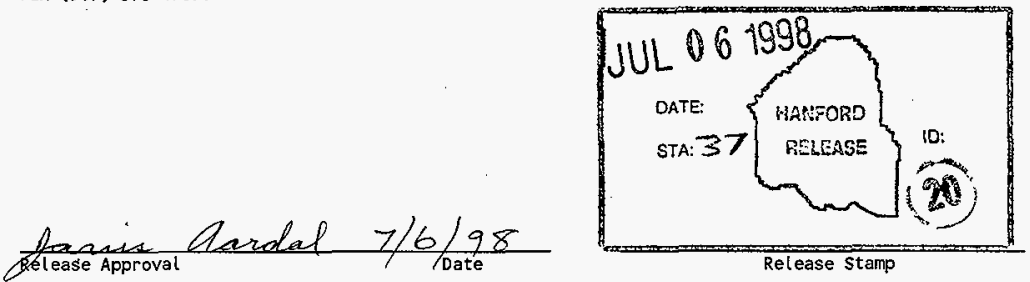


\title{
WASTE FEED DELIVERY ENVIRONMENTAL PERMITS AND APPROVALS PLAN
}

May 1998

\author{
I. G. Papp \\ R.D. Potter \\ R. L. Treat
}

\author{
Prepared for \\ Lockheed Martin Hanford Corporation \\ Richland, Washington
}


HNF-2401, Rev. 0

\section{CONTENTS}

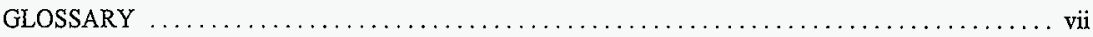

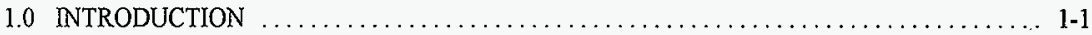

1.1 SCOPE OF THE WASTE FEED DELIVERY PROGRAM $\ldots \ldots \ldots \ldots \ldots \ldots \ldots \ldots 1-1$

1.1.1 Waste Feed Composition and Quantity $\ldots \ldots \ldots \ldots \ldots \ldots \ldots \ldots \ldots \ldots \ldots \ldots \ldots \ldots \ldots, 1-2$

1.1 .2 Waste Feed Sources and Sequencing $\ldots \ldots \ldots \ldots \ldots \ldots \ldots \ldots \ldots \ldots \ldots \ldots \ldots \ldots \ldots \ldots \ldots, 2$

1.1.3 Projects and Equipment Upgrades to Support Waste Feed Delivery ............. 1-2

1.2 STRUCTURE AND CONTENT OF THIS PERMITS AND APPROVALS PLAN $\ldots \ldots \ldots 1-3$

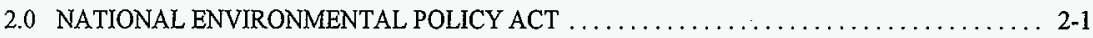

2.1 SUMMARY OF KEY REQURREMENTS AND APPROVAL PROCESS $\ldots \ldots \ldots \ldots \ldots$ 2-1

2.2 APPLICABILITY TO WASTE FEED DELIVERY ACTIONS $\ldots \ldots \ldots \ldots \ldots \ldots \ldots .2-2$

2.3 SATISFYING APPLICABLE NATIONAL ENVIRONMENTAL POLICY ACT

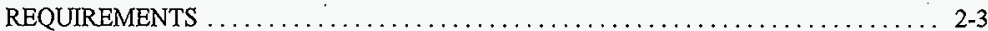

2.3.1 Available Alternatives $\ldots \ldots \ldots \ldots \ldots \ldots \ldots \ldots \ldots \ldots \ldots \ldots \ldots \ldots \ldots, 2-3$

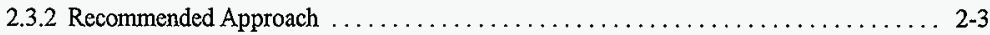

2.4 PRELIMINARY COST AND SCHEDULE ESTIMATES $\ldots \ldots \ldots \ldots \ldots \ldots \ldots \ldots \ldots .2-4$

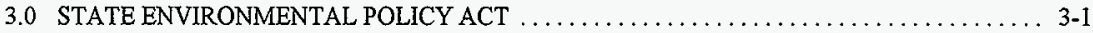

3.1 SUMMARY OF KEY REQUIREMENTS AND APPROVAL PROCESS $\ldots \ldots \ldots \ldots \ldots$. 3-1

3.2 APPLICABILITY TO WASTE FEED DELIVERY ACTIONS $\ldots \ldots \ldots \ldots \ldots \ldots \ldots$. 3-1

3.3 SATISFYING APPLICABLE STATE ENVIRONMENTAL POLICY ACT

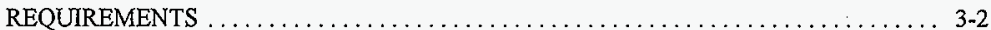

3.3.1 Available Alternatives $\ldots \ldots \ldots \ldots \ldots \ldots \ldots \ldots \ldots \ldots \ldots \ldots \ldots \ldots \ldots \ldots, 3-2$

3.3 .2 Recommended Approach $\ldots \ldots \ldots \ldots \ldots \ldots \ldots \ldots \ldots \ldots \ldots \ldots \ldots \ldots, 3-2$

3.4 PRELIMINARY COST AND SCHEDULE ESTIMATES $\ldots \ldots \ldots \ldots \ldots \ldots \ldots \ldots \ldots, 3-2$

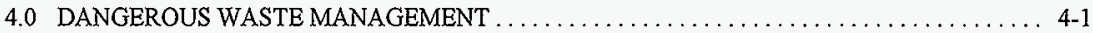

4.1 SUMMARY OF KEY REQURREMENTS AND PERMITTING PROCESS . . . . . . . . 4 4-1

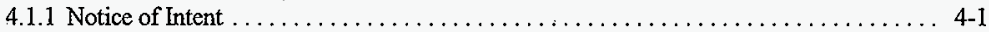

4.1 .2 Part A $\ldots \ldots \ldots \ldots \ldots \ldots \ldots \ldots \ldots \ldots \ldots \ldots \ldots \ldots \ldots \ldots \ldots \ldots \ldots \ldots \ldots \ldots \ldots, 1$

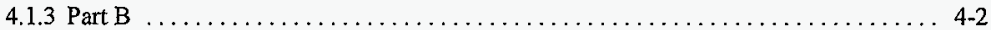

4.2 APPLICABILITY TO WASTE FEED DELIVERY ACTIONS $\ldots \ldots \ldots \ldots \ldots \ldots \ldots, 4-2$

4.3 SATISFYING APPLICABLE DANGEROUS WASTE MANAGEMENT

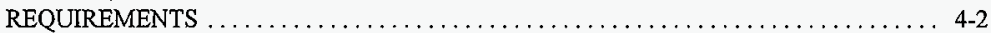

4.3.1 Available Alternatives $\ldots \ldots \ldots \ldots \ldots \ldots \ldots \ldots \ldots \ldots \ldots \ldots \ldots \ldots \ldots \ldots \ldots, 4,3$

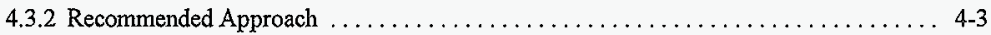

4.4 PRELIMINARY COST AND SCHEDULE ESTIMATES $\ldots \ldots \ldots \ldots \ldots \ldots \ldots \ldots, 4-4$

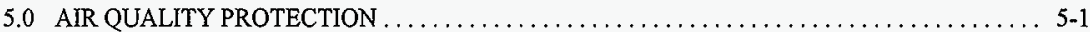

5.1 SUMMARY OF KEY REQURREMENTS AND PERMTTTING PROCESSES . . . . . . . . 5-1

5.1 .1 Prevention of Significant Deterioration $\ldots \ldots \ldots \ldots \ldots \ldots \ldots \ldots \ldots \ldots \ldots \ldots, 5-1$

5.1.2 Toxic Air Pollutants/Notice of Construction ....................... 5-1

5.1.3 Radioactive Air Emissions/Notice of Construction . . . . . . . . . . . . . . . . 5-2

5.1.4 Hanford Sitewide Air Operating Permit ........................ 5-2

5.2 APPLICABILITY TO WASTE FEED DELIVERY ACTIONS . . . . . . . . . . . . . . 5-3 
HNF-2401, Rev. 0

CONTENTS (cont)

5.3 SATISFYING APPLICABLE AIR QUALITY PROTECTION REQURREMENTS ...... 5-3

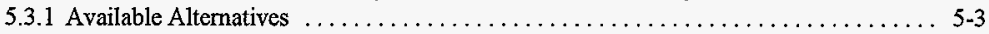

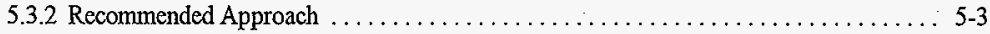

5.4 PRELIMINARY SCHEDULE AND COST ESTIMATE $\ldots \ldots \ldots \ldots \ldots \ldots \ldots \ldots \ldots, 5-5$

6.0 RADIATION PROTECTION STANDARDS/MONITORING .................... 6-1

6.1 SUMMARY OF KEY REQUIREMENTS AND APPROVAL PROCESS $\ldots \ldots \ldots \ldots \ldots$ 6-1

6.1.1 Routine Environmental Monitoring $\ldots \ldots \ldots \ldots \ldots \ldots \ldots \ldots \ldots \ldots \ldots \ldots, 6,1$

6.1 .2 EPA Requirements for Radiation Protection $\ldots \ldots \ldots \ldots \ldots \ldots \ldots \ldots \ldots \ldots$ 6-1

6.1 .3 Radioactive Waste Management $\ldots \ldots \ldots \ldots \ldots \ldots \ldots \ldots \ldots \ldots \ldots \ldots, 6-2$

6.1.4 DOE Order 5400.1 Environmental Compliance Documents .................. 6-2

6.2 APPLICABILITY TO WASTE FEED DELIVERY ACTIONS $\ldots \ldots \ldots \ldots \ldots \ldots \ldots \ldots, 6.2$

6.3 SATISFYING APPLICABLE RADIATION PROTECTION REQUIREMENTS . . . . . . 6 6-3

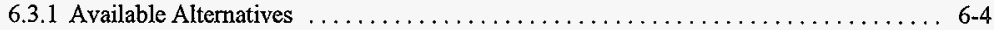

6.3 .2 Recommended Approach $\ldots \ldots \ldots \ldots \ldots \ldots \ldots \ldots \ldots \ldots \ldots \ldots \ldots \ldots, 6,4$

6.4 PRELIMINARY COST AND SCHEDULE ESTIMATES $\ldots \ldots \ldots \ldots \ldots \ldots \ldots \ldots .6 .4$

7.0 MISCELLANEOUS ASSESSMENTS, PERMITS, AND APPROVALS $\ldots \ldots \ldots \ldots \ldots \ldots \ldots$. $7-1$

7.1 SUMMARY OF KEY REQUREMENTS AND PROCESSES $\ldots \ldots \ldots \ldots \ldots \ldots \ldots .7,1$

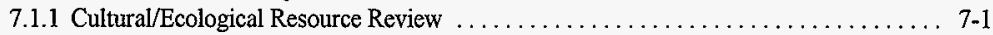

7.1 .2 Site Location $\ldots \ldots \ldots \ldots \ldots \ldots \ldots \ldots \ldots \ldots \ldots \ldots \ldots \ldots \ldots \ldots \ldots \ldots \ldots \ldots \ldots \ldots \ldots, 1$

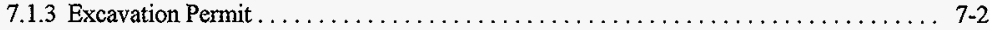

7.1.4 American Indian Tribal Government Agreements . . . . . . . . . . . . . . . . . . . . . 7-2

7.1 .5 Endangered Species Act Compliance ............................. 7-2

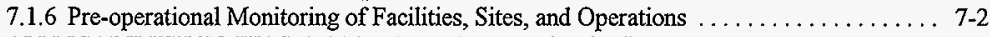

7.2 APPLICABILITY TO WASTE FEED DELIVERY ACTIONS $\ldots \ldots \ldots \ldots \ldots \ldots \ldots \ldots$. $7-3$

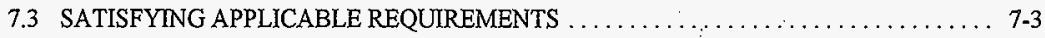

7.4 PRELIMINARY COST AND SCHEDULE ESTIMATES $\ldots \ldots \ldots \ldots \ldots \ldots \ldots \ldots \ldots \ldots \ldots \ldots$

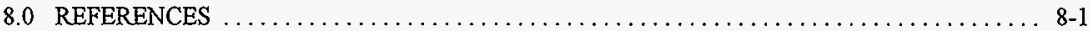

\section{APPENDICES}

A ENVIRONMENTAL REQUIREMENTS CHECKLIST FOR

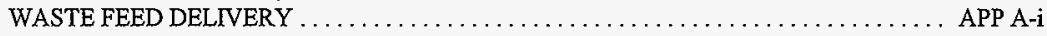

B SUMMARY OF INFORMATION AND DATA NEEDS $\ldots \ldots \ldots \ldots \ldots \ldots \ldots \ldots$ APP B-i

C WASTE FEED DELIVERY PERMITTING SCHEDULE $\ldots \ldots \ldots \ldots \ldots \ldots \ldots \ldots$ APP C-i 
HNF-2401, Rev. 0

\section{FIGURES}

1. Waste Feed Delivery Transfer Routes and Supporting Projects $\ldots \ldots \ldots \ldots \ldots \ldots \ldots \ldots \ldots \ldots$ F1-1

2. Waste Feed Delivery Supporting Project Activities $\ldots \ldots \ldots \ldots \ldots \ldots \ldots \ldots \ldots \ldots \ldots \ldots \ldots \ldots \ldots \ldots$

\section{TABLES}

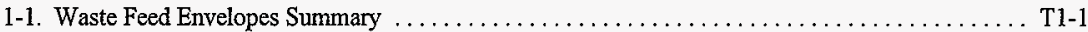

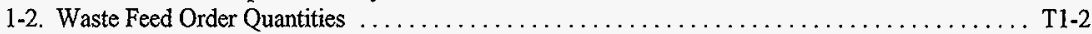

1-3. Low-Activity Waste Feed Delivery Source Tanks and Feed Batches $\ldots \ldots \ldots \ldots \ldots \ldots \ldots$ TI-3

1-4. High-Level Waste Feed Delivery Source Tanks and Feed Batches ................. T1-4

1-5. Summary of Waste Feed Delivery Supporting Project Scopes and Schedules ............ T1-5

5-1. Air Approvals for Project W-058, Cross-Site Transfer System .................... T5-1

5-2. Air Approvals and Documentation for Project W-151, Tank AZ-101 Waste Retrieval System,

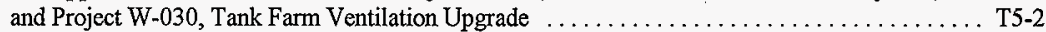

5-3. Air Approvals for Project W-320, Tank C-106 Sluicing ........................ T5-3

5-4. Air Approvals for Project W-211, Initial Tank Retrieval System $\ldots \ldots \ldots \ldots \ldots \ldots \ldots$ T5-4 
HNF-2401, Rev. 0

This page intentionally left blank. 
HNF-2401, Rev. 0

\section{GLOSSARY}

ALARA

ALARACT

ASIL

BARCT

BHI

CAA

CDR

CFR

CSB

CWC

CX

CY

DNR

DOE

DOE-RL

DOT

DST

EA

Ecology

EDE

EIS

EMP

EPA

EREQ

ETF

FDH

FEIS

FEMP

FONSI

$\mathrm{FY}$

HLW

HLWIS

HNE

HWVP

HVAC

IHLW

ILAW as low as reasonably achievable

as low as reasonably achievable control technology

acceptable source impact level

best available radionuclide control technology

Bechtel Hanford, Inc.

Clean Air Act of 1977

conceptual design report

Code of Federal Regulations

Canister Storage Building

Central Waste Complex

categorical exclusion

calendar year

Department of Natural Resources

U.S. Department of Energy

U.S. Department of Energy, Richland Operations Office

U.S. Department of Transportation

double-shell tank

environmental assessment

Washington State Department of Ecology

effective dose equivalent

environmental impact statement

environmental monitoring plan

U.S. Environmental Protection Agency

environmental requirements checklist

200 Area Effluent Treatment Facility

Fluor Daniel Hanford, Inc.

final environmental impact statement

facility effluent monitoring plan

finding of no significant impact

fiscal year

high-level waste

high-level waste interim storage

Hanford Nuclear Facility (document identifier)

Hanford Waste Vitrification Plant

heating, ventilation, and air conditioning

immobilized high-level waste

immobilized low-activity waste 
HNF-2401, Rev. 0

\section{GLOSSARY (cont)}

LAW

LERF

LMHC

NAAQS

NEPA

NESHAPS

NOC

NOD

NOI

NRC

PHMC

PNNL

PSD

PSE

QA

RCRA

ROD

$\mathrm{RQ}$

SA

SEPA

SESC

SNF

SQE

SQER

SST

SWCX

TAPS

TBD

T-BACT

TEDF

Tri-Party Agreement

TSD

TWRS

VOCs

WAC

WDOH

WFD

WMH low-activity waste

Liquid Effluent Retention Facility

Lockheed Martin Hanford Corporation

National Ambient Air Quality Standards

National Environmental Policy Act of 1969

National Emissions Standards for Hazardous Air Pollutants

notice of construction

notice of deficiency

notice of intent.

Nuclear Regulatory Commission

Project Hanford Management Contract

Pacific Northwest National Laboratory

prevention of significant deterioration

preliminary safety evaluation

quality assurance

Resource Conservation and Recovery Act of 1976

record of decision

reportable quantity

(EIS) supplement analysis

State Environmental Policy Act of 1971

SGN Eurisys Services Corporation

spent nuclear fuel

small quantity emission

small quantity emission rates

single-shell tank

sitewide categorical exclusion

toxic air pollutants

to be determined

best available control technology for toxics

200 Area Treated Effluent Disposal Facility

Hanford Federal Facility Agreement and Consent Order

treatment, storage, and/or disposal

Tank Waste Remediation System

volatile organic compounds

Washington Administrative Code

Washington State Department of Health

waste feed delivery

Waste Management Federal Services of Hanford, Inc. 
HNF-2401, Rev. 0

\section{WASTE FEED DELIVERY \\ ENVIRONMENTAL PERMITS AND APPROVALS PLAN}

\subsection{INTRODUCTION}

This document describes the range of environmental actions, including required permits and other agency approvals, that may affect waste feed delivery (WFD) activities in the Hanford Site's Tank Waste Remediation System (TWRS). This plan expands on the summary level information in the Tank Waste Remediation System Environmental Program Plan (HNF-1773) to address requirements that are most pertinent to WFD. This plan outlines alternative approaches to satisfying applicable environmental standards, and describes selected strategies for acquiring permits and other approvals needed for WFD to proceed. Appendices at the end of this plan provide preliminary cost and schedule estimates for implementing the selected strategies. The rest of this section summarizes the scope of WFD activities, including important TWRS operating information, and describes in more detail the objectives, structure, and content of this plan.

\subsection{SCOPE OF THE WASTE FEED DELIVERY PROGRAM}

The U.S. Department of Energy (DOE) and the Washington State Department of Ecology (Ecology) jointly issued Tank Waste Remediation System, Hanford Site, Richland, Washington, Final Environmental Impact Statement (TWRS EIS) (DOE/EIS-0189F) in August 1996. In February 1997, DOE issued a Record of Decision (ROD) (62 FR 8693) identifying the selected alternative, Phased Implementation, from the TWRS EIS; Ecology has concurred in the selection of this alternative. Under the Phased Implementation alternative, tank waste will continue to be safely stored until the waste is retrieved from the tanks for treatment and disposal. Treatment and disposal will be achieved by implementing a demonstration phase (Phase 1), followed by a full-scale production phase (Phase 2). The primary purposes of Phase 1 are to verify that tank waste can be retrieved, transferred, and delivered to privately operated treatment facilities, and to confirm that privatized treatment processes can effectively immobilize low-activity waste (LAW) and high-level waste (HLW) feeds from the tanks. For now, it is assumed that Phase 2 projects and operations will be privatized and will be developed on the basis of Phase 1 results. For purposes of this plan, the scope of the WFD permitting and approval discussions has been limited to Phase 1 activities.

The Tank Waste Remediation System Mission Analysis Report (HNF-SD-WM-MAR-008) provides detailed information concerning the full scope of the TWRS program, including implementation of the ROD and TWRS EIS strategies. In general, the activities that are most relevant to WFD include:

- Installing and operating an initial tank waste retrieval system to improve the capacity to allow consolidation of double-shell tank (DST) waste, support mitigation of safety issues, and deliver LAW/HLW feed to the Private Contractors

- Installing and operating retrieval systems to retrieve selected tank waste (primarily liquid waste) for separation and immobilization, and selected tank waste for HLW immobilization

- Transferring LAW to Private Contractor feed tanks and transferring selected waste for HLW processing directly to the HLW immobilization facility. 
HNF-2401, Rev. 0

The following sections provide summary level information concerning composition of the planned waste feeds, planned sources and sequencing of the waste feeds, and the facility projects and equipment upgrades needed to accomplish WFD.

\subsubsection{Waste Feed Composition and Quantity}

The current privatization approach involves the treatment of four feed envelopes $(A, B, C$, and $D)$ during Phase 1 to demonstrate waste handling and processing capabilities. Envelopes A, B, and C provide three LAW feed variations, while envelope $D$ is a HLW feed. These envelopes are summarized in Table 1-1.

The current privatization approach requires the Private Contractor(s) to treat a minimum amount of LAW and HLW feed (minimum order quantity) during Phase 1. The opportunity also exists to increase the quantity of waste feed up to a maximum amount (maximum order quantity). The minimum and maximum order quantities are presented in Table 1-2.

The Phase 1A Privatization Contracts between the DOE, Richland Operations Office (DOE-RL) and the Private Contractors (DOE-RL 1996a and DOE-RL 1996b) provide detailed specifications for the currently planned waste feed envelopes and order quantities. The envelope specifications and order quantities might change based on the Phase $1 \mathrm{~B}$ contract negotiations between DOE-RL and the Private Contractors.

\subsubsection{Waste Feed Sources and Sequencing}

The source tanks that will be used to provide waste feed have been selected to be consistent with the envelope specifications and order quantities in the Privatization Contracts. The sequence for retrieving, transferring, and delivering waste feed was selected to meet the contract requirements. Where flexibility existed, other factors were considered, including ease of retrieval, integrating tank usage with the operation waste volume projections, emptying source tanks promptly, processing more dilute waste first to free up tank space quicker, and simplification of construction project designs and schedules.

During privatization Phase 1, Tank Farms will continue to make other transfers not directly related to staging of feed. These other transfers are required to support ongoing waste management activities such as receipt of remediation waste, salt well pumping, single-shell tank (SST) retrieval, and transfer to 242-A Evaporator. Both the feed staging and waste management transfers were analyzed to ensure the demands on tank space will not exceed available DST space.

Table 1-3 shows the source of feed, the pre-staging tank (when required), and the approximate timing for the retrieval, staging, and delivery of each LAW (envelopes A, B, and C) feed batch. Table 1-4 shows the same types of information for each HLW (envelope D) feed batch. The Tank Waste Remediation System Operation and Utilization Plan (HNF-SD-WM-SP-012) provides additional detail on the sources, sequencing, and other operating scenario information for WFD.

\subsubsection{Projects and Equipment Upgrades to Support Waste Feed Delivery}

Targeted LAW feed will be retrieved from source tanks and transferred via valve pits, transfer pipes, and diversion boxes to two intermediate staging tanks (AP-102 and AP-104). The retrieved LAW feed will be blended and adjusted, as needed, and verified to meet contract requirements (e.g., envelope specifications). Verified LAW feed will be transferred to two feed tanks (AP-106 and AP-108) that will be operated by the 
Private Contractor(s). When staging tanks are emptied, LAW for the next feed batch will be retrieved, Targeted HLW feed will be retrieved from source tanks, and prepared (e.g., sludge washing) and conditioned in two staging tanks (AZ-101 and AZ-102) to meet specifications. The adjusted HLW will be verified to meet contract requirements and the verified HLW feed will be transferred directly to the HLW immobilization facility.

Figure 1 shows the major transfer routes, facilities, and equipment currently planned to support mobilization of the waste and delivery of LAW and HLW feed to the Private Contractor(s). (Note: The process configuration depicted on Figure 1 is preliminary at this time pending final privatization contract and WFD program direction by DOE-RL.) As shown in Figure 1, there are several new facilities and equipment upgrades, such as new valve pits and transfer lines, that are required and that will be (or have been) completed under various projects.

Four projects (W-030, W-058, W-151, and W-320) are scheduled for completion in or soon after fiscal year (FY) 1998. These projects improve the aging waste tank ventilation system, provide two new cross-site transfer lines, provide mixer pumps for tank AZ-101, and provide equipment to remove waste from tank C-106. Other projects (W-211, W-314, W-454, W-TBD1, W-TBD2, W-XXX, and W-519) will continue beyond FY 1998. These projects include adding mixer pumps, transfer systems, and other equipment necessary to mobilize the feed, adding in-tank sludge washing capability, and providing utilities and other infrastructure support.

For purposes of this plan, the WFD supporting projects encompass the principal events and occurrences for which environmental compliance must be assured. Thus, this plan focuses primarily on the projects, and specific project activities, to determine which permits or other agency approvals are required. Table 1-5 summarizes the scopes of the nine WFD supporting projects and their general schedules for completion. Figure 2 provides a more complete listing of the activities included in the projects. Additional information on the scope of the WFD supporting projects can be found in the Waste Feed Delivery Technical Basis Document (HNF-1939).

\subsection{STRUCTURE AND CONTENT OF THIS PERMITS AND APPROVALS PLAN}

This plan describes the environmental actions, including permits and other agency approvals, necessary to support WFD. The objectives of this plan include:

- Identify the range of potentially relevant environmental standards

- Determine environmental requirements expected to apply to WFD

- Identify and describe the expected permit and approval needs for WFD

- Identify alternative approaches for environmental compliance

- Recommend preferred strategies for acquiring needed permits and approvals

- Estimate the costs and schedules for implementing the preferred WFD strategies.

It is the intent of this plan to address environmental actions for all WFD activities. As a result, this plan encompasses a more comprehensive range of permits and approvals than might apply to any single project or activity. This plan establishes programmatic strategies for acquiring the environmental permits and approvals needed to support WFD, and provides a rollup of current and planned WFD environmental actions, schedules, and costs. The program-level strategies and program-wide rollup will help improve the integration of environmental actions between projects and within TWRS, and offer specific benefits such as: 
- Better understanding of the interfaces and dependencies between project and permit activities

- Early identification of potential conflicts between permit timeframes and project schedules

- Better coordination and use of the resources suppoiting environmental compliance efforts

- Promoting consistent decisionmaking and applying lessons learned

- Discovering opportunities to improve efficiency (e.g., by combining common approval requests).

It is expected that this plan will be supported by project-specific environmental permit and approval plans. These project-specific plans will rely on the strategies set forth in this plan to determine the permit and approval needs and to define the overall approach to environmental compliance. Each project-specific plan should provide only the supplemental information needed to address:

- Environmental permit or approval actions unique to the project and not covered by this plan. Examples could include enforcement orders or prior permit conditions with special requirements for a particular facility or operation. Any unique requirements should be described in the project-specific plan, along with analyses of their impacts and recommended strategies for compliance.

- The detailed permit and approval efforts, schedules, and resource needs. Although the steps for acquiring one type of permit or approval are typically the same (e.g., obtain designs, assemble application, respond to agency comments), each project will have its own list of tasks, sequencing of events, and design, construction, testing, and operating requirements. The permit and approval efforts will need to be tailored in the project-specific plan to match the particular work, schedule, and resource needs of the project.

Project-specific environmental permit and approval plans should be developed as soon as it is possible to correlate project deadlines (e.g., construction start, equipment install and test) with the time constraints (e.g., agency review cycles, public comment periods) usually encountered while acquiring the necessary permits or approvals.

The method used in this plan (and with narrower focus in the project-specific plans) to identify the relevant environmental requirements and determine the preferred compliance strategies can be summarized in the following general steps.

Applicability Assessment. An environmental requirements (EREQ) checklist, identifying the range of potentially applicable standards, is used to select those environmental actions that (based on current plans) are likely to apply to WFD. This assessment process and rationale for the selected environmental actions are documented in Appendix A. Appendix B summarizes the typical submittals and information needs associated with the selected environmental actions.

Alternatives and Strategies. The required environmental actions are evaluated in more depth to determine what alternative compliance approaches might be available. For some requirements, several approaches could exist so the pros and cons of each alternative will be considered. The evaluation process results in recommended strategies that balance the WFD project needs with the applicable environmental requirements.

Implementing Preferred Strategies. The preferred strategies are implemented through specific actions, such as applying for permits, submitting approval requests, or establishing monitoring programs. Each of these actions depends on the completion of separate, usually sequential tasks (e.g., assembly of application data, submittal to the agency, response to comments). Appendix $C$ presents a summary level discussion of the actions and tasks needed to implement the WFD environmental 
strategies, along with preliminary cost and schedule estimates. These estimates are expected to change as the scopes of specific projects evolve, and as particular actions become better defined.

As noted previously, the EREQ checklist provided in Appendix A assesses the complete range of potentially relevant environmental standards for applicability to WFD. Many of these standards were found to be inapplicable, and others only to be applicable under specific circumstances which, at this time, are not expected for WFD. Those standards that were determined to be applicable to WFD are evaluated in the main body of this plan for the alternative compliance and preferred approaches. Thus, the rest of this plan is organized into technical sections for each of the major applicable environmental areas as follows.

2.0 National Environmental Policy Act. This section addresses the need to consider the range of environmental and socio-economic impacts associated with performing WFD activities.

3.0 State Environmental Policy Act. This section addresses the need to satisfy Washington State's counterpart to the federal program covered in Section 2.0.

4.0 Dangerous Waste Management. This section addresses actions associated with generating, treating, storing, and/or disposing of mixed liquid and solid waste streams.

5.0 Air Quality Protection. This section addresses actions that could emit chemically and/or radiologically hazardous constituents to the air.

6.0 Radiation Protection. This section addresses the need to ensure public and personnel protection for all potential radiation exposure routes.

7.0 Miscellaneous Assessments, Permits, and Approvals. This section addresses requirements that might not be fully covered by the preceding environmental programs, such as preservation of archaeological sites or protection of endangered species habitats.

8.0 References. Provides a listing of references cited in this plan.

Each of these sections (except for the References) includes a summary of the environmental standard and associated permit/approval processes, a brief description of what specific requirements apply to WFD activities, descriptions of the alternatives available for satisfying the applicable requirements, a more complete discussion of the recommended compliance approach, and a citation of the preliminary costs and schedules associated with implementing the preferred strategy. 
HNF-2401, Rev. 0

This page intentionally left blank. 


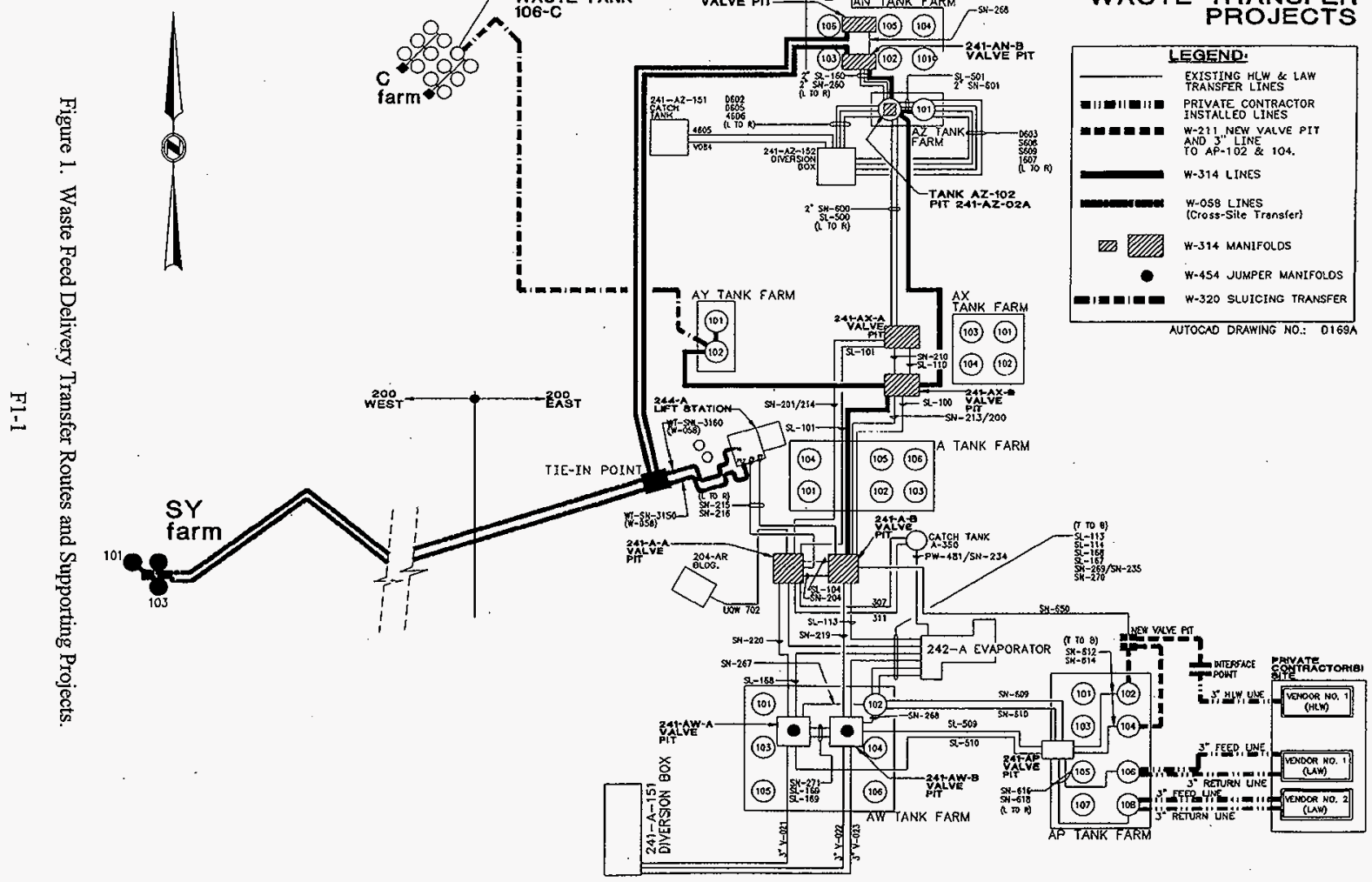




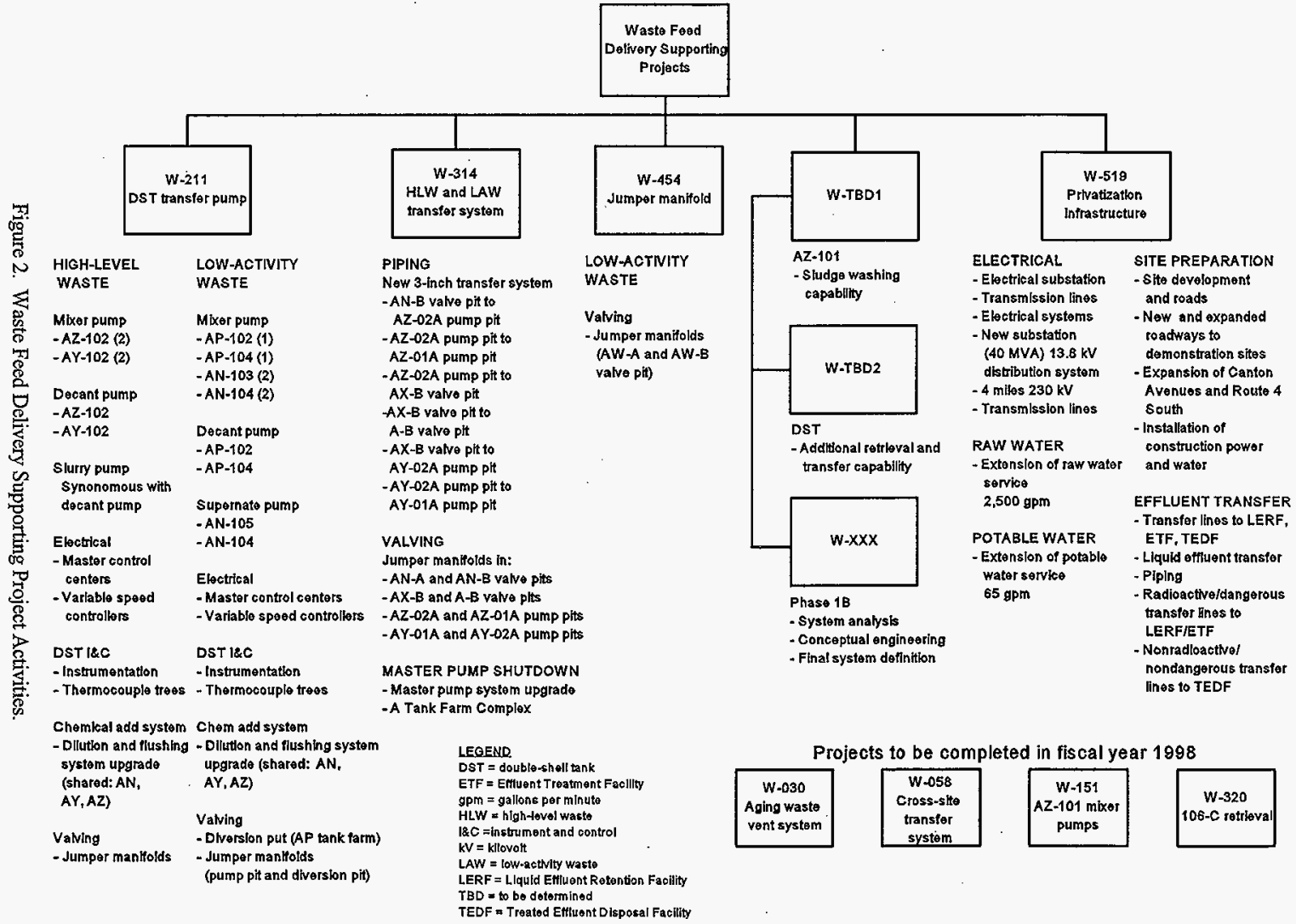


HNF-2401, Rev. 0

Table 1-1. Waste Feed Envelopes Summary*.

\begin{tabular}{|c|l|}
\hline Envelope & \multicolumn{1}{|c|}{ Description } \\
\hline A & $\begin{array}{l}\text { Waste that tests the production capacity and fission-product removal efficiency. Produces a final } \\
\text { product in which waste loading is limited by sodium. }\end{array}$ \\
\hline B & $\begin{array}{l}\text { Similar to } \mathrm{A}, \text { except that final product waste loading is limited by minor component concentrations (Cl, } \\
\left.\mathrm{Cr}, \mathrm{F}, \mathrm{PO}_{4}, \text { or } \mathrm{SO}_{4}\right) . \text { These minor components could stress the Private Contractor facilities' offgas } \\
\text { systems. }\end{array}$ \\
\hline C & $\begin{array}{l}\text { Contains organic complexants that keep }{ }^{90} \mathrm{Sr} \text { and transuranics in solution. Could require organic } \\
\text { destruction. }\end{array}$ \\
\hline D & $\begin{array}{l}\text { Contains insoluble solids classified as } \mathrm{HLW} \text {. The envelope approximates solids content in three } \\
\text { existing DSTs: AZ-101, AZ-102, and AY-102 (including sluiced and transferred contents of C-106). }\end{array}$ \\
\hline
\end{tabular}

* Source: Adapted from Tank Waste Remediation System Retrieval and Disposal Mission Readiness-to-Proceed Memorandum (HNF-2019). 
HNF-2401, Rev. 0

Table 1-2. Waste Feed Order Quantities*.

\begin{tabular}{|c|c|c|c|}
\hline \multicolumn{2}{|l|}{ Waste feed } & \multirow{2}{*}{$\frac{\begin{array}{c}\text { Minimum } \\
\text { (metric tons) }\end{array}}{2,600}$} & \multirow{2}{*}{$\frac{\begin{array}{c}\text { Maximum } \\
\text { (metric tons) }\end{array}}{4,900}$} \\
\hline LAW & A & & \\
\hline \multirow{2}{*}{$\begin{array}{c}\text { (Na per Private } \\
\text { Contractor) }\end{array}$} & B & 100 & 1,000 \\
\hline & $\mathrm{C}$ & 100 & 2,400 \\
\hline \multicolumn{2}{|l|}{ HLW } & 245 & 465 \\
\hline
\end{tabular}

$\mathrm{Na}=$ sodium

NVOL $=$ nonvolatile solids

* Source: Tank Waste Remediation System Retrieval and Disposal Mission Readiness-to-Proceed Memorandum (HNF-2019). 
HNF-2401, Rev. 0

Table 1-3. Low-Activity Waste Feed Delivery Source Tanks and Feed Batches*.

\begin{tabular}{|c|c|c|c|c|c|c|c|c|}
\hline \multirow[b]{2}{*}{ Envelope } & \multirow[b]{2}{*}{ Batch } & \multirow{2}{*}{$\begin{array}{l}\text { Source tank } \\
\text { (static date) }\end{array}$} & \multirow{2}{*}{$\begin{array}{c}\text { Pre-stage } \\
\quad \operatorname{tank} \\
\text { (static date) }^{\mathbf{2}}\end{array}$} & \multicolumn{4}{|c|}{ Approximate timing } & \multirow{2}{*}{$\begin{array}{l}\text { Batch - } \\
\text { contractor }\end{array}$} \\
\hline & & & & $\begin{array}{c}\text { Start } \\
\text { retrieval }\end{array}$ & $\begin{array}{c}\text { Begin } \\
\text { staging }\end{array}$ & $\begin{array}{l}\text { Batch } \\
\text { ready }\end{array}$ & $\begin{array}{c}\text { Batch } \\
\text { delivered }\end{array}$ & \\
\hline \multirow{11}{*}{ A } & \multirow{2}{*}{1} & \multirow{2}{*}{$\begin{array}{l}\text { AN-105 } \\
\text { (Now) }\end{array}$} & \multirow{2}{*}{ - } & \multirow{2}{*}{$03 / 2001$} & \multirow{2}{*}{$06 / 2001$} & $12 / 2001$ & $12 / 2001$ & $1-\mathrm{C} 1$ \\
\hline & & & & & & $12 / 2001$ & $12 / 2001$ & $1-\mathrm{C} 2$ \\
\hline & \multirow{2}{*}{2} & \multirow{2}{*}{$\begin{array}{l}\text { AN-104 } \\
\text { (Now) }\end{array}$} & \multirow{2}{*}{ - } & \multirow{2}{*}{$10 / 2001$} & \multirow{2}{*}{$12 / 2001$} & $06 / 2002$ & $01 / 2003$ & $2-\mathrm{C} 1$ \\
\hline & & & & & & $06 / 2002$ & $01 / 2003$ & $2-\mathrm{C} 2$ \\
\hline & \multirow{2}{*}{3} & \multirow{2}{*}{$\begin{array}{c}\text { AW-101 } \\
\text { (Now) }\end{array}$} & \multirow{2}{*}{ - } & \multirow{2}{*}{$01 / 2003$} & \multirow{2}{*}{$03 / 2003$} & $08 / 2003$ & $10 / 2003$ & $3-\mathrm{Cl}$ \\
\hline & & & & & & $09 / 2003$ & $10 / 2003$ & $3-\mathrm{C} 2$ \\
\hline & \multirow{2}{*}{4} & \multirow{2}{*}{$\begin{array}{c}\text { AN-103 } \\
\text { (Now) }\end{array}$} & \multirow{2}{*}{ - } & \multirow{2}{*}{$05 / 2003$} & \multirow{2}{*}{$10 / 2003$} & $03 / 2004$ & $05 / 2004$ & $4-\mathrm{C} 1$ \\
\hline & & & & & & $03 / 2004$ & $05 / 2004$ & $4-\mathrm{C} 2$ \\
\hline & \multirow{3}{*}{5} & $\begin{array}{c}\text { AP-101 } \\
(04 / 1999)\end{array}$ & \multirow{3}{*}{-} & \multirow{3}{*}{$05 / 2004$} & \multirow{3}{*}{$05 / 2004$} & $10 / 2004$ & $03 / 2005$ & $5-\mathrm{Cl}$ \\
\hline & & $\begin{array}{c}\mathrm{AW}-104 \\
(10 / 1999)\end{array}$ & & & & $11 / 2004$ & $03 / 2005$ & $5-\mathrm{C} 2$ \\
\hline & & Shim caustic & & & & & & \\
\hline$n$ & & AZ-101 & $A Y-101$ & & & $08 / 2005$ & $01 / 2006$ & $6 \cdot \mathrm{Cl}$ \\
\hline B & 6 & AZ-102 & $(01 / 2002)$ & $03 / 2005$ & $03 / 2005$ & $08 / 2005$ & $03 / 2006$ & $6-C_{2}$ \\
\hline & 7 & & & & & $01 / 2006$ & $03 / 2006$ & $7-\mathrm{Cl}$ \\
\hline & 7 & AN-107 & & & & $03 / 2006$ & $05 / 2006$ & $7-\mathrm{C} 2$ \\
\hline & $\therefore$ & $(11 / 1997)$ & - & $01 / 2006$ & $01 / 2006$ & $01 / 2006$ & $04 / 2006$ & $8-\mathrm{Cl}$ \\
\hline & 8 & & & & & $03 / 2006$ & $06 / 2006$ & $8-\mathrm{C} 2$ \\
\hline & & AN-102 & & & (1) & $08 / 2006$ & $08 / 2006$ & $9-\mathrm{Cl}$ \\
\hline & 9 & (Now) & - & $04 / 2006$ & $04 / 2006$ & $10 / 2006$ & $10 / 2006$ & $9-\mathrm{C} 2$ \\
\hline $\mathrm{C}$ & 10 & AN-106 & 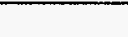 & 080006 & nom & $12 / 2006$ & $04 / 2007$ & $10-\mathrm{C} 1$ \\
\hline & 10 & $(07 / 1999)$ & - & $08 / 2006$ & $08 / 2006$ & $03 / 2007$ & $06 / 2007$ & $10-\mathrm{C} 2$ \\
\hline & 17 & SY-101 & AN-102 & 10 Mpos & & $08 / 2007$ & $11 / 2007$ & $11-\mathrm{Cl}$ \\
\hline & 11 & (Now) & $\begin{array}{c}\text { AN-107 } \\
(05 / 2006)\end{array}$ & $12 / 2005$ & $04 / 2007$ & $10 / 2007$ & $01 / 2008$ & $11-\mathrm{C} 2$ \\
\hline & 12 & SY-103 & AN-102 & 12000 & 1110007 & $03 / 2008$ & $09 / 2008$ & $12-\mathrm{Cl}$ \\
\hline & 12 & (Now) & $\begin{array}{c}A N-107 \\
(03 / 2008)\end{array}$ & $12 / 2000$ & $11 / 2007$ & $05 / 2008$ & $11 / 2008$ & $12-\mathrm{C} 2$ \\
\hline
\end{tabular}

'The term 'static' is used to define when the targeted waste feed is in the individual tank.

'The 'Batch Ready' date is when the feed is ready for transfer to the Private Contractor's facility.

* Source: Tank Waste Remediation System Retrieval and Disposal Mission Readiness-to-Proceed Memorandum (HNF-2019). 
HNF-2401, Rev. 0

Table 1-4. High-Level Waste Feed Delivery Source Tanks and Feed Batches*.

\begin{tabular}{|c|c|c|c|c|c|c|c|c|c|}
\hline \multirow[b]{2}{*}{ Envelope } & \multirow[b]{2}{*}{ Batch } & \multirow{2}{*}{$\begin{array}{l}\text { Source } \\
\text { tank }\end{array}$} & \multirow{2}{*}{$\begin{array}{l}\text { Sluicing } \\
\text { receiver }\end{array}$} & \multirow{2}{*}{$\begin{array}{l}\text { Washing and } \\
\text { staging tank }\end{array}$} & \multicolumn{5}{|c|}{ Approximate timing } \\
\hline & & & & & $\begin{array}{l}\text { Begin } \\
\text { sluicing }\end{array}$ & $\begin{array}{c}\text { Begin } \\
\text { pre-stagings }\end{array}$ & $\begin{array}{c}\text { Begin } \\
\text { conditioning }\end{array}$ & $\begin{array}{l}\text { Batch } \\
\text { ready* }\end{array}$ & $\begin{array}{c}\text { Batch } \\
\text { delivered }\end{array}$ \\
\hline \multirow{12}{*}{ D } & 1 & \multirow{2}{*}{ AZ-101 } & \multirow{2}{*}{ - } & \multirow{2}{*}{ AZ-101 } & \multirow{2}{*}{ - } & \multirow{2}{*}{ - } & \multirow{2}{*}{$10 / 2000$} & \multirow{2}{*}{$08 / 2001$} & $05 / 2002$ \\
\hline & 2 & & & & & & & & $02 / 2003$ \\
\hline & 3 & \multirow{2}{*}{$A Z-102$} & \multirow{2}{*}{ - } & \multirow{2}{*}{ AZ-102 } & \multirow{2}{*}{ - } & \multirow{2}{*}{ - } & \multirow{2}{*}{$04 / 2002$} & \multirow{2}{*}{$02 / 2003$} & $11 / 2003$ \\
\hline & 4 & & & & & & & & $08 / 2004$ \\
\hline & 5 & \multirow{5}{*}{ AY -102} & \multirow{5}{*}{ AY -102} & \multirow{5}{*}{ AZ-101 } & \multirow{5}{*}{$10 / 1998$} & \multirow{5}{*}{$06 / 2003$} & \multirow{5}{*}{$06 / 2003$} & \multirow{5}{*}{$04 / 2004$} & $06 / 2005$ \\
\hline & 6 & & & & & & & & $01 / 2006$ \\
\hline & 7 & & & & & & & & $07 / 2006$ \\
\hline & 8 & & & & & & & & $02 / 2007$ \\
\hline & 9 & & & & & & & & $08 / 2007$ \\
\hline & 10 & \multirow{3}{*}{ C-104 } & \multirow{3}{*}{ AY-102 } & \multirow{3}{*}{ AZ-102 } & \multirow{3}{*}{$07 / 2004$} & \multirow{3}{*}{$07 / 2005$} & \multirow{3}{*}{$07 / 2005$} & \multirow{3}{*}{$05 / 2006$} & $03 / 2008$ \\
\hline & 11 & & & & & & & & $12 / 2008$ \\
\hline & 12 & & & & & & & & $10 / 2009$ \\
\hline
\end{tabular}

*The 'Batch Ready' date is when the feed is ready for transfer to the Private Contractor's facility.

* Source: Tank Waste Remediation System Retrieval and Disposal Mission Readiness-to-Proceed Memorandum (HNF-2019). 
Table 1-5. Summary of Waste Feed Delivery Supporting Project Scopes and Schedules.

\begin{tabular}{|c|c|c|}
\hline Project No. and title & Scope & Schedules \\
\hline $\begin{array}{l}\frac{\text { W-030 }}{\text { Tank Farm Ventilation }} \\
\text { Upgrade }\end{array}$ & $\begin{array}{l}\text { Install new ventilation systems on the aging waste } \\
\text { tanks (AZ and AY Tank Farms) }\end{array}$ & $\begin{array}{l}\text { Project will be completed in } \\
\text { FY } 1998\end{array}$ \\
\hline $\begin{array}{l}\text { W-058 } \\
\text { Cross-Site Transfer } \\
\text { System }\end{array}$ & $\begin{array}{l}\text { Provide two new transfer lines from } 200 \text { West to } 200 \\
\text { East, inciuding associated mechanical equipment and } \\
\text { instrumentation }\end{array}$ & $\begin{array}{l}\text { Project will be completed in } \\
\text { FY } 1998\end{array}$ \\
\hline $\begin{array}{l}\frac{W-151}{\text { Tank AZ-101 Waste }} \\
\text { Retrieval System }\end{array}$ & $\begin{array}{l}\text { Provides two mixer pumps and ancillary equipment } \\
\text { for mobilizing the sludge in tank AZ-101 }\end{array}$ & $\begin{array}{l}\text { Project will be completed in } \\
\text { FY } 1999\end{array}$ \\
\hline$\frac{\mathrm{W}-320}{\text { Tank C-106 Sluicing }}$ & $\begin{array}{l}\text { Provides equipment and modifications to resolve } \\
\text { high heat issue in tank C- } 106 \text { and transfer contents of } \\
\operatorname{tank} \text { C-106 to tank AY-102 }\end{array}$ & $\begin{array}{l}\text { Construction will be completed } \\
\text { and sluicing initiated in } \\
\text { FY } 1999\end{array}$ \\
\hline $\begin{array}{l}\text { W-211 } \\
\text { Initial Tank Retrieval } \\
\text { System }\end{array}$ & $\begin{array}{l}\text { Mobilization and transfer systems for waste retrieval } \\
\text { in } 10 \text { DSTs }\end{array}$ & FY 1996 through 2005 \\
\hline$\frac{\text { W-314 }}{\text { Tank Farm Restoration }}$ & Provides infrastructure upgrades to the tank farms & FY 1997 through 2007 \\
\hline$\frac{\text { W-454 }}{\text { Jumper Manifold }}$ & $\begin{array}{l}\text { Replace and add new jumper manifolds to the AW-A } \\
\text { and AW-B valve pits (Note: This project currently } \\
\text { is on hold and may be cancelled or consolidated with } \\
\text { another project.) }\end{array}$ & Schedule is being developed \\
\hline $\begin{array}{l}\frac{W-X X X}{\text { Phase } 1 B \text { Systems }} \\
\text { Analysis }\end{array}$ & $\begin{array}{l}\text { Perform system analysis and conceptual engineering } \\
\text { to define the complete system required to achieve } \\
\text { Phase 1B feed delivery requirements }\end{array}$ & $\begin{array}{l}\text { Project definition initiated in } \\
\text { FY } 1998\end{array}$ \\
\hline W-TBD1 & Sludge washing capability in tank AZ-101 & FY 1998 through 2001 \\
\hline W-TBD2 & Additional DST retrieval and transfer systems & FY 1998 through 2007 \\
\hline $\begin{array}{l}\text { W-519 } \\
\text { Privatization Phase } 1 \\
\text { Infrastructure }\end{array}$ & $\begin{array}{l}\text { Provides immobilization infrastructure (roads, water, } \\
\text { electricity, effluent transfer lines) for Private } \\
\text { Contractor(s) }\end{array}$ & FY 1998 through 2001 \\
\hline
\end{tabular}

DST $=$ double-shell tank.

$\mathrm{FY}=$ fiscal year.

$\mathrm{TBD}=$ to be determined. 
HNF-2401, Rev. 0

This page intentionally left blank. 
HNF-2401, Rev. 0

\subsection{NATIONAL ENVIRONMENTAL POLICY ACT}

The National Environmental Policy Act (NEPA) of 1969 was enacted to ensure that environmental matters are considered before federal actions are initiated that might affect the quality of the human environment. The DOE regulation [Title 10 of the Code of Federal Regulations (CFR) Part 1021] promulgated under NEPA was developed to conform with 40 CFR Parts 1500-1508 regulations and to categorize the environmental impacts associated with various DOE proposals or actions.

\subsection{SUMMARY OF KEY REQUIREMENTS AND APPROVAL PROCESS}

The NEPA standards require that environmental considerations be identified and evaluated early in the planning process for all proposed federal actions. Therefore, all proposed actions on the Hanford Site must have NEPA determinations completed before actions commence. Only DOE and/or DOE-RL can approve the correct level of NEPA review on the Hanford Site.

The NEPA implementing regulations require an environmental impact statement (EIS) for major federal actions that significantly affect the quality of the human environment, which results in a ROD. The NEPA regulations require that if there is uncertainty about the necessity for an EIS, an environmental assessment (EA) should be prepared. An EA documents analysis of a proposed action through evaluation of its potential impacts on the environment. The EA provides the information for determining the need to prepare an EIS, or results in a finding of no significant impact (FONSI) determination. The NEPA regulations also list categorical exclusions (CXs) to describe categories of actions that normally do not require an EIS or EA. Documentation of the bases for CXs still must be completed. The general scope of each of these types of NEPA documentation is as follows:

Environmental Impact Statement. An EIS is required if it is determined that the proposed action will have impacts to the human environment that might be significant. A Notice of Intent (NOI) published in the Federal Register officially starts the EIS process. A draft. EIS is published describing a proposed action and alternatives. The final EIS is published after incorporating public comments. The EIS process results in publication of the ROD in the Federal Register. Finally, a Mitigation Action Plan (MAP) is prepared detailing specific mitigative measures relating to the final EIS and ROD.

Supplement Analysis. A supplement analysis (SA) is prepared if there are substantial changes or potentially significant new circumstances or information relevant to environmental concerns for an action covered by an existing EIS with a ROD. Approval authority for the SA usually is delegated to DOE-RL if the applicable EIS is delegated by the DOE Secretary.

Environmental Assessment. An EA is a concise document with alternatives to a proposed action. The EA analyzes the environmental consequences of the proposed action and the alternatives to that action, including the consequences of accidents and routine operations and the cumulative and long-term impacts. The relationship of the proposed action to federal, state, and local land use plans, policies, and regulations also is discussed in the EA. The EA has the following three defined functions:

(1) To provide sufficient information to determine whether a proposed action requires preparation of an EIS or if it is eligible for a FONSI

(2) To provide an interdisciplinary review of a proposed action and alternatives, and to analyze their potential environmental impacts 
(3) To facilitate preparation of an EIS if one is determined to be needed. If an EIS is not needed, DOE and/or DOE-RL will issue a FONSI.

Categorical Exclusion. If the potential impacts to the environment of a proposed action are within the integral elements and clearly outside of extraordinary circumstances, and the proposed action falls within a category of actions not normally requiring an EA or an EIS, the action may be eligible for a CX. All DOE categorical exclusions are listed in 10 CFR Part 1021. If no pre-approved sitewide Categorical Exclusion (SWCX) exists, a CX is prepared describing the action and identifying the appropriate CX.

Sitewide Categorical Exclusion. All SWCXs are reviewed and approved periodically by DOE-RL and are listed on the Hanford IntraNet Homepage found under Programs \& Activities through Environmental Services under "NEPA" and "NEPA Site-Wide Categorical Exclusions". The SWCXs could be slightly modified from those CXs listed in 10 CFR Part 1021, and are specific for use by the Hanford Site. The SWCX actions must still meet all integral elements and be outside of any extraordinary circumstances as depicted in 10 CFR Part 1021.

The NEPA documentation process begins by identifying the purpose, scope, and location of a proposed action. If a proposed action appears to be covered under an existing approved EIS or EA, the relevant ROD or FONSI should be examined to ensure the proposed action is adequately bounded by existing documentation. The associated NEPA evaluation results in a determination that a SA is needed, which concludes whether or not the existing EIS or EA adequately covers the proposed action. If it is determined that a proposed action is not covered by existing environmental documentation, the action would be evaluated for coverage under the established CXs (including SWCXs). If the proposed action is covered by a CX, a memorandum is prepared that summarizes the proposed action and its background, along with an explanation of how the action meets the minimum requirements of a CX. If the proposed action is not covered by a CX, DOE and/or DOE-RL will decide whether the action warrants an EA, an SA to an existing EIS, a supplemental EIS (SEIS), or a full EIS.

If an EA is prepared, the EA results in a final determination that either the proposed action is a major action significantly affecting the environment and requires an EIS or a FONSI should be issued. If a proposed action is similar to an action addressed in an existing EIS, DOE and/or DOE-RL could elect to prepare a SEIS. A SA is prepared when it is unclear if a SEIS is required. The SA would contain sufficient information for the DOE and/or DOE-RL to determine whether the existing EIS should be supplemented, a new EIS should be prepared, or that no further NEPA documentation is required.

More detail on NEPA documentation and the NEPA approval processes can be found in HNF-PRO-452, NEPA, SEPA, Cultural and Natural Resources and in HNF-SP-0903, NEPA Source Guide for the Hanford Site. Appendix B includes a summary of the minimum data and/or information needs required for developing NEPA documentation.

\subsection{APPLICABILITY TO WASTE FEED DELIVERY ACTIONS}

The proposed action, conduct of WFD, includes upgrading and constructing waste feed transfer lines, transferring waste from tanks to privately operated waste immobilization facilities, and related supporting activities. As documented in Appendix A, WFD is considered to be a major action requiring appropriate NEPA documentation. There are two existing, approved EISs that have applicability for TWRS waste retrieval and disposal activities, including WFD. The first is the TWRS EIS (DOE/EIS-0189F) and the TWRS ROD (62 FR 8693). The second is the Safe Interim Storage of Hanford Tank Wastes 
Environmental Impact Statement (SIS EIS) (DOE/EIS-0212), and the ROD for the SIS EIS (60 FR 61687). The decisions in the TWRS EIS ROD and SIS EIS ROD include the scope of the identified WFD supporting projects and associated Phase I WFD activities. Additional NEPA documentation exists in project-related EAs and are listed in HNF-SP-0903. The available alternatives for satisfying the NEPA documentation requirements and a preferred NEPA documentation strategy are discussed in Section 2.3.

\subsection{SATISFYING APPLICABLE NATIONAL ENVIRONMENTAL POLICY ACT REQUIREMENTS}

The following sections describe the alternatives available for obtaining appropriate NEPA documentation and the recommended approach for the WFD system environmental planning basis.

\section{3,1 Available Alternatives}

The following alternatives exist for NEPA documentation regarding the action to transfer waste:

1. Identify that the action to be taken is covered by an existing EIS ROD and if a SA determination is necessary

2. Prepare a supplement to an appropriate existing EIS to generally address the action to be taken. The supplement would discuss alternatives or impacts not discussed or bounded by the existing EIS. A possible means of doing this is to use the existing Final EISs (DOE/EIS-0189 and DOE/EIS-0212)

3. Prepare an EA to determine if an EIS or supplemental EIS is needed or if a FONSI is appropriate

4. Evaluate the existing TWRS EIS and SIS EIS RODs to determine if a ROD amendment is appropriate

5. Prepare a new EIS or supplemental EIS.

\subsubsection{Recommended Approach}

The recommended approach is to adhere to the ROD for the TWRS EIS (62 FR 8693) and the ROD for the SIS EIS (60 FR 61687). The RODs were based on the Final TWRS EIS (DOE/EIS-0189F) co-authored by the DOE and Washington State Department of Ecology (Ecology) and the Final SIS EIS (DOE/EIS-0212).

The 'Phased Implementation Alternative' was identified in the Final TWRS EIS as the preferred alternative. Pertinent items within the TWRS ROD for Phase 1 implementation are as follows:

- Upgrading tank farm infrastructure, including waste transfer, instrumentation, ventilation, and electrical systems

- Removing pumpable liquid from single-shell tanks (SSTs), transferring newly generated waste from ongoing activities to DSTs 
- Completing construction of and operating the new replacement cross-site transfer system to facilitate regulatory compliant waste transfers from 200 West to 200 East Area and continue operating the existing transfer pipeline

- Transferring liquid waste to receiver tanks and transferring selected waste for high-level waste processing directly to the high-level waste vitrification facility.

- Returning a portion of the sludge, from separations processes, to the DSTs for future retrieval and treatment

- Performing separations to remove selected radionuclides from the low-activity waste feed stream and transferring the waste to the high-level waste vitrification facility.

Pertinent items from the preferred alternative decision in the SIS EIS allowed for the following:

- Construction and operation of the replacement cross-site transfer system for transfer of salt well liquids and 200 West Area facility waste to DSTs in the 200 East Area

- Removing salt well liquids from older SSTs to reduce the likelihood of liquid waste escaping from corroded tanks

- Transferring liquid waste through the existing cross-site transfer system until the proposed replacement cross-site transfer system becomes operational

- Providing adequate tank waste storage for future waste volumes associated with tank farm and Hanford Facility operations.

In summary, further programmatic NEPA documentation is not required at this time, but it is recommended that the WFD Program confirm approach with DOE-RL contacts. At the task specific level, however, it is recommended that the project engineer review work packages and engineering change packages through use of a NEPA screening form, to ensure that changes to project actions are still within the scope of the TWRS and SIS EIS RODs, TWRS SA, or applicable categorical exclusion.

\subsection{PRELIMINARY COST AND SCHEDULE ESTIMATES}

There are no additional NEPA documentation actions identified at this time for the current scope of WFD supporting projects and related activities. Consequently, cost and schedule estimates have not been developed for WFD NEPA documentation. 
HNF-2401, Rev. 0

\subsection{STATE ENVIRONMENTAL POLICY ACT}

The State Environmental Policy Act (SEPA) (Chapter 43.21C Revised Code of Washington) is the Washington State equivalent of NEPA, and requires evaluation of environmental impacts associated with a project or an agency action before approval of the project or action is granted. The SEPA Rules, Chapter 197-11 of the Washington Administrative Code (WAC), are the implementing regulations.

\subsection{SUMMARY OF KEY REQUIREMENTS AND APPROVAL PROCESS}

The SEPA Rules are promulgated and managed by Ecology. SEPA requires evaluation by a state or local agency of environmental impacts associated with an action under its jurisdiction before approval by the agency. The SEPA review process usually is triggered whenever a state or local action is required, such as issuing, or modifying a state or local permit. SEPA encourages the grouping of similar, related actions (e.g., all necessary permits and approvals) within a single SEPA review so that all associated impacts can be considered at once.

The typical method of addressing SEPA requirements is to complete a SEPA environmental checklist that provides information necessary for Ecology to make a threshold determination on the significance of the proposed action. If the proposed action is categorically exempt or nonsignificant, further action under SEPA. is not required. If the proposed action is significant, preparation of a SEPA EIS is required. An option exists for adoption of existing NEPA document(s) (e.g., a NEPA EIS) to fulfill the agency's responsibilities.

On the Hanford Site, the SEPA process begins when approval(s) or modification(s) (e.g., license, permit) must be obtained for a proposed action to proceed. A SEPA checklist may be prepared and submitted with the license or permit application. Alternatively, when a proposed action has been addressed under NEPA documentation, such as an approved EIS/ROD or EA/FONSI, Ecology may be asked to adopt the NEPA documentation in lieu of the SEPA checklist. If Ecology concurs, a separate Determination of Nonsignificance (DNS) and Statement of Adoption are published under SEPA to correspond with the NEPA ROD or FONSI.

More detail on SEPA documentation and the SEPA approval processes can be found in NEPA, SEPA, Cultural and Natural Resources (HNF-PRO-452). Appendix B includes a summary of the minimum data and/or information needs required for developing SEPA documentation.

\subsection{APPLICABILITY TO WASTE FEED DELIVERY ACTIONS}

The proposed action, conduct of WFD, includes upgrading and constructing waste feed transfer lines, transferring waste from tanks to privately operated waste immobilization facilities, and related supporting activities, and many of these proposed actions will require permits and other approvals from state agencies (e.g., Ecology). As documented in Appendix A, WFD is considered to require appropriate SEPA documentation. As discussed in Section 2.0 of this plan, there is existing NEPA documentation that addresses the WFD scope: the TWRS EIS (DOE/EIS-0189F) and TWRS ROD (62 FR 8693); the SIS EIS (DOE/EIS-0212) and SIS ROD (60 FR 61687); and project-related EAs such as are listed in HNF-SP-0903. This NEPA documentation anticipated and addressed the impacts associated with WFD supporting projects and associated Phase 1 WFD activities, and was prepared with substantial involvement by Ecology. The TWRS EIS was issued jointly by DOE and Ecology. Ecology has concurred with the Phased Implementation 
alternative selected by DOE in the TWRS ROD. SEPA documentation alternatives and a preferred SEPA documentation strategy are discussed in Section 3.3.

\subsection{SATISFYING APPLICABLE STATE ENVIRONMENTAL POLICY ACT REQUIREMENTS}

The following sections describe the alternatives available for obtaining appropriate SEPA documentation and the recommended approach for the WFD system environmental planning basis.

\subsubsection{Available Alternatives}

The following alternatives exist for compliance with SEPA:

- Submit a letter to Ecology for SEPA adoption and/or provide a briefing to appropriate regulatory agencies (Ecology is the lead agency) stating that DOE-RL believes existing environmental documentation provided to or prepared by Washington State agencies, and issuance of permits by those agencies, covers this action.

- Submit a SEPA environmental checklist in conjunction with an application for permit(s) needed (e.g., air, RCRA, building) and let Ecology determine if an EIS is required.

\subsubsection{Recommended Approach}

The recommended approach is to inform Ecology that the TWRS EIS (DOE/EIS-0189F), the SIS EIS (DOE/EIS-0212), and issuance of permits necessary for constructing and operating WFD, cover this action and request Ecology adopt the existing NEPA documentation for SEPA.

\section{3,4 PRELIMINARY COST AND SCHEDULE ESTIMATES}

Based on assumed implementation of the recommended approach, and assuming Ecology concurs with the opinion that SEPA has been satisfied, there are few additional SEPA documentation actions expected identified at this time.

The effort to seek Ecology's concurrence with this approach will be relatively nominal. The cost to implement this concurrence effort is estimated at $\$ 5-10 \mathrm{~K}$, and is estimated to require 30 to 90 days to complete. This information will be added to Appendix C. 
HNF-2401, Rev. 0

\subsection{DANGEROUS WASTE MANAGEMENT}

A comprehensive national program was enacted under the Resource Conservation and Recovery Act (RCRA) of 1976 to mandate that hazardous (dangerous) waste will be treated, stored, and disposed of so as to minimize the present and future threat to human health and the environment. In Washington State, WAC 173-303, Dangerous Waste Regulations are the implementing regulations.

\subsection{SUMMARY OF KEY REQUIREMENTS AND PERMITTING PROCESS}

WAC 173-303 regulations apply to all facilities within Washington State that treat, store, and/or dispose of dangerous waste. These regulations are equivalent to, or more stringent than, the federal hazardous waste regulations. Under the dangerous waste program, all treatment, storage, and/or disposal (TSD) units must obtain a permit. Units that were in existence on November 19,1980, were granted an interim status permit with the submittal of a Part A, Form 3, identifying the intent to treat, store, and/or dispose of dangerous waste. A final status permit is granted after final administrative disposition of the Part $B$ documentation.

The process for obtaining a RCRA permit consists of three collective submittals. Each submittal consists of various levels of detailed information concerning the TSD unit. The three submittals are the NOI; the Part A, Form 3, permit application (Part A); and the Part B permit application (Part B).

\subsubsection{Notice of Intent}

A NOI is required for proposed facilities or expansion at an existing facility. Expansion includes enlargement of land surface area, the addition of new dangerous waste processes, or an increase in overall design capacity. The NOI contains preliminary information concerning the proposed facility and/or expansion. The NOI requires a general process description, operating capacities, waste type, a topographic map, and a statement of environmental conditions, which could include a SEPA environmental checklist or a SEPA adoption letter.

In accordance with WAC 173-303-281, a NOI is filed with Ecology, published, and submitted to the public (public reading rooms). A public notification is then made in a local daily newspaper for 14 consecutive days. The NOI must be filed 150 days before submittal of the Part A. Typically, the Part A is prepared during the 150 day period. The overall NOI/Part A process normally requires approximately 11 months to complete and submit.

\subsubsection{Part A}

The Part A includes process design capacity, process description, dangerous waste numbers and estimated annual quantity, description of dangerous waste, facility diagrams, photographs, geographic location, and facility owner and operator/co-operator certification. The Part $A$ is submitted no earlier than 150 days following submittal of the NOI to Ecology and the public. The preparation process requires approximately 6 months to complete, including reviews by Fluor Daniel Hanford, Inc. (FDH) team and DOE-RL and certification by FDH and DOE-RL.

Interim status expansion can be requested from Ecology via the Part A. Once the revised Part A and NOI are submitted, construction can proceed if Ecology grants interim status expansion under the Part A. Otherwise, 
the Part B must be submitted and a final status permit issued by Ecology before any construction can proceed. Under limited circumstances, Ecology may allow construction to commence before final status approval.

\subsubsection{Part B}

The Part B provides detailed descriptions of the processes to be used for the management of dangerous waste. Requirements include information on design capacity of such processes, specific dangerous waste types to be managed, operation and maintenance, training, contingency planning, closure, and other relevant information concerning the TSD unit.

The Part B is evaluated by Ecology for completeness and technical adequacy. The latter includes plausibility, general detail of plans and procedures, and protection of human health and the environment. Resolution on inadequacies can be reached formally by Ecology issuing a notice of deficiency (NOD) or informally by the use of a workshop or similar process. A workshop process also can be used to resolve NODs. Resolution of inadequacies would involve DOE-RL, the FDH team, and Ecology, and would probably result in revisions to the Part $B$.

When satisfied with the Part B, Ecology prepares a draft Part B permit. This draft permit is published for public and interagency review. On completion of the public review period, significant public comments are factored into the final status permit issued by Ecology. For the Hanford Site, one dangerous waste permit has been issued for the Hanford Facility. On completion of the unit-specific Part B process, each TSD unit will be appended to the Hanford Facility Dangerous Waste Permit. Generally, preparation of a Part B requires approximately 14 months through the first certification cycle, and the total duration could last approximately 3 to 6 years. Information needs required for development of the RCRA documentation is provided in Appendix B.

\subsection{APPLICABILITY TO WASTE FEED DELIVERY ACTIONS}

The proposed action, conduct of WFD, includes upgrading and constructing waste feed transfer lines, transferring waste from tanks to privately operated waste immobilization facilities, and related supporting activities, and many of these proposed actions will require permits and other approvals from state agencies (e.g., Ecology). As documented in Appendix A, WFD is subject to the dangerous waste TSD requirements and must be covered adequately under the appropriate RCRA interim status and/or final status permits.

As previously noted, the Hanford Site has been issued a sitewide final status permit that is being periodically amended to include unit-specific requirements for each of the major TSD facilities at the Hanford Site. Many of the anticipated Phase 1 WFD activities involve the Tank Farms, and primarily the DST System. The DST System is currently covered under interim status, and a unit-specific final status permit application is being prepared for submittal to Ecology. It will be necessary to ensure that the DST System interim status and eventual final status permit are consistent with and adequately cover the planned WFD projects and activities.

\subsection{SATISFYING APPLICABLE DANGEROUS WASTE MANAGEMENT REQUIREMENTS}

The following sections describe the alternatives available for obtaining appropriate RCRA documentation and permits and the recommended approach for the WFD system environmental planning basis. 


\subsubsection{Available Alternatives}

The scope of work identified for WFD so far does not impact the current permitting documents and can be performed under interim status for the DST System. As the design evolves, it should be reviewed by the knowledgeable personnel to ensure that compliant systems are being proposed, which can be permitted in the future. Relevant design media and system descriptions must be provided to TWRS Environmental for incorporation into the DST System Part B final status permit application. Once the final status DST System permit is issued, formal modification of the permit is required before major changes to the DST System can be implemented. Three basic alternatives have been identified for consideration:

1. Integrate the WFD activities with the DST System TSD permitting efforts, and stay consistent with the current schedule and plans for maintaining interim status and obtaining a final status permit for the DST System.

2. Integrate the WFD activities with some other TSD permit action (e.g., the LAW vitrification facility final status permit) that is scheduled for a later submittal date when there will be more complete design and operating information for WFD.

3. Seek to establish an independent TSD permitting process for WFD that would be more closely aligned with the schedule and plans for WFD activities.

It should be noted that it would be very difficult to distinguish WFD activities from the DST System, so although the last two alternatives are theoretically feasible, they are much less practical. However, should significant problems arise (e.g., denial of the DST System final status permit) that would prevent or substantially delay WFD, Alternative 2. or 3. could become a more viable option.

\subsubsection{Recommended Approach}

The current recommended approach is to review the WFD systems projects for changes in scope (e.g., changes in processes or waste types and increases to design capacity) and ensure that sufficient coverage is identified in the DST System RCRA Part A during interim status. This approach also ensures that changes to the Part A are reflected in the DST System. As needed to maintain interim status, the DST System Part A should be updated to include new components, structures, or operating systems associated with WFD. During preparation, the Part B final status permit application for the DST System should include the available and required design-level information for the planned WFD systems, structures and components. Inclusion of conceptual and pre-conceptual information should be avoided. However, it may be advantageous to address the overall WFD scope in the final status permit to establish a basis for and to simplify future permit modifications (for newly defined WFD projects and activities). Knowledgeable FDH Team personnel should determine the available options for addressing WFD in the DST System Part B permit application, evaluate the benefits and disadvantages, and implement a preferred alternative. This plan can be updated to reflect the preferred alternative once it is developed.

The following assumptions apply to this recommendation.

(a) The Private Contractor furnishes a vitrified waste meeting land disposal restriction requirements as contracted.

(b) Changes to the scope identified within this plan will require re-evaluation for new impacts, and as needed, changes to the Part $A$. 
(c) The DST System Part B is revised to reflect changes in piping, transfer systems and, if needed, the addition of above or belowground waste storage tanks.

(d) The SST Closure Work Plan would be revised to include WFD SST transfer lines and, if needed, additional storage tanks (though this effort is not within the current Phase I and II work scope).

(e) Hanford Facility Dangerous Waste Permit Application, General Information Portion (DOE/RL-9I-28) would be revised to provide current information.

\subsection{PRELIMINARY COST AND SCHEDULE ESTIMATES}

Refer to Appendix C for schedule. Should the need for an NOI and Part A, Form 3, change be necessary, the - preparation and submittal costs would be approximately as follows:

- Preparation and processing of an NOI (if required) - 200 hours at $\$ 60$ per hour is $\$ 12 \mathrm{~K}$ and includes:

- Preparation of an NOI - 100 hours

- Review, DOE-RL approval, and submittal - 100 hours.

- Preparation and submittal of $\mathrm{P}$ art $\mathrm{A}$, Form 3 (if required) - 100 hours at $\$ 60$ per hour is $\$ 6 \mathrm{~K}$ and includes:

- Preparation or modification of Part A - 80 hours

- Operations certification and transmittal to Ecology - 20 hours.

- DST System Part B (supported through separate cost account)

- SST-CWP revision (supported through separate cost account).

Additional costs might be incurred for submittals associated with as-built drawings, Title II, and design media at a cost of $\$ 3 \mathrm{~K}$ for each submittal. 
HNF-2401, Rev. 0

\subsection{AIR QUALITY PROTECTION}

The purpose of the Clean Air Act (CAA) is to protect public health and welfare by safeguarding air quality, bringing polluted air into compliance and protecting clean air from degradation. In Washington State, the provisions of the CAA are implemented by EPA, Ecology, Washington State Department of Health (WDOH), and local air authorities.

\subsection{SUMMARY OF KEY REQUIREMENTS AND PERMITTING PROCESSES}

The air permitting process is based on emission standards administered by regulatory agencies and contained in the following regulations:

- National Emissions Standards for Hazardous Air Pollutants (NESHAPs) (40 CFR 61 Subpart H)

- Prevention of Significant Deterioration (PSD) standards (40 CFR 52.21 and WAC 173-400)

- Operating Permit Regulation (WAC 173-401)

- Ambient Air Quality Standards for Radionuclides (WAC 173-480)

- Radiation Protection - Air Emissions (WAC 246-247)

- Controls for New Sources of Toxic Air Pollutants (TAPs) (WAC 173-460).

These regulations establish standards and rules applicable to the control and/or the prevention of the emission of air contaminants. Three main requirements to be met are: use of best available control technology; quantification of air pollutant emissions; and demonstration of human health and environmental protection. Detailed information on the emissions abatement system, the gaseous effluent monitoring system, and the nature of all emissions to the atmosphere are required for submissions made pursuant to the CAA.

\subsubsection{Prevention of Significant Deterioration}

Under WAC 173-400-141, criteria pollutants are subject to the PSD program. Ecology has incorporated, by reference, the federal PSD requirements under 40 CFR 52.21. If emissions tesulting from a project's activities exceed the trigger levels of any of the 14 criteria pollutants following PSD review for the activity, a PSD permit application must be prepared and approved before construction.

\subsubsection{Toxic Air Pollutants/Notice of Construction}

Nonradioactive air emissions of concern fall into two categories: toxic air pollutants (TAPs) and criteria pollutants. Ecology regulates both categories pursuant to WAC 173-460 and 173-400-110, respectively. 
The TAPs regulations require the use of best available control technology for toxics (T-BACT). Also, if emissions exceed the small quantity emission rates (SQERs), dispersion modeling must be performed to demonstrate that the offsite concentrations for each constituent does not exceed their applicable acceptable source impact level (ASIL). For constituents without a SQER, dispersion modeling also is required.

Ecology requires the submittal and subsequent approval of a Notice of Construction (NOC) for the construction of new sources of TAPs; the modification of an existing source that increases its emissions (increase is calculated based on conditions existing before modification of the source); or the replacement or substantial alteration of the emissions control technology at an existing source. The need for a project to obtain Ecology's approval can be made when data are available to review the scope, determine new source reviews applicability, and estimate any increase in emissions.

\subsubsection{Radioactive Air Emissions/Notice of Construction}

Radioactive air emissions currently are regulated by the WDOH, pursuant to WAC 246-247, and the EPA, pursuant to $40 \mathrm{CFR} 61$ Subpart $\mathrm{H}$. Both agencies require an approval to construct if the planned activity causes a new source of radioactive air emissions or if there is a modification to an existing source that causes any increase in emissions (increase is calculated without the benefit of emissions control equipment) as a result of the planned activity.

The WDOH requires the use of best available radionuclide control technology (BARCT) for all significant modifications or the use of as low as reasonably achievable control technology (ALARACT) for all nonsignificant modifications. A BARCT assessment evaluates the universe of available control technologies and selects the most effective control technology from all known feasible alternatives. The ALARACT assessment requires the use of radionuclide emission control technology that achieves emissions levels that are consistent with the philosophy of ALARA. This is demonstrated by evaluating the control system in relation to applicable technology standards and other control technologies that have been operated successfully in similar applications. A significant modification is one where the potential-to-emit airborne radioactivity is at a rate that could increase the total effective dose equivalent to the maximally exposed offsite individual by 1.0 millirem per year or more (assuming normal operations and no emissions control equipment in place).

The EPA requires the sampling and monitoring system to meet specific criteria when the effective dose equivalent to the maximally exposed offsite individual resulting from the activity is 0.1 millirem per year or greater (assuming normal operations and no emissions control equipment in place).

\subsubsection{Hanford Sitewide Air Operating Permit}

The WDOH Division of Radiation Protection enforces state regulatory controls for radioactive air emissions as allowed under the Act, Section 118. WAC 246-247 requires applicable controls and annual reporting of all radioactive air emissions. The Hanford Site operates under a state license for such emissions. The conditions specified in the license will be incorporated into the upcoming Hanford Site air operating permit, scheduled to be issued in July 1998. The air operating permit will include both radioactive emissions now covered by licenses and nonradioactive emissions. 
HNF-2401, Rev. 0

\subsection{APPLICABILITY TO WASTE FEED DELIVERY ACTIONS}

The proposed action, conduct of WFD, includes upgrading and constructing waste feed lines, transferring waste from tanks to privately operated waste immobilization facilities, and supporting projects and operations. The WFD activities (operation of retrieval systems and transferring waste) will require several air-related permits and approvals before commencement of activities. These permits and approvals will be issued by several regulatory agencies, including the EPA, Ecology, and WDOH.

\subsection{SATISFYING APPLICABLE AIR QUALITY PROTECTION REQUIREMENTS}

The following sections describe the alternatives available for obtaining appropriate air quality documentation and the recommended approach for the WFD system environmental planning basis.

\subsubsection{Available Alternatives}

Various avenues could be evaluated in an effort to support the air permitting for WFD activities. The length of the permitting process depends on the quantity of emissions and the availability of necessary information. The alternatives open for consideration are as follows.

1. Use existing air permitting documentation within identified scope, emissions limits, and time constraints (refer to Tables 5-1 through 5-4).

2. Obtain WAC 246-247, 40 CFR 61 Subpart H (NESHAPs), and WAC 173-460 (TAPs) approvals when information necessary to complete the applications is available.

3. Obtain WAC 246-247, 40 CFR 61 Subpart H (NESHAPs), and WAC 173-460 (TAPs) approvals separately as information to complete the applications becomes available.

4. Obtain WAC 246-247 and WAC 173-460 (TAPs) approvals in a phased approach. Permit applications are prepared for and represent a project that affects an individual emission point. Obtaining separate approvals, by segmenting a project into separate NOCs, is not allowed under the Clean Air Act. To receive the required approvals for preconstruction or preliminary activities early in the project's schedule, a phased approach could be implemented.

The NESHAPs regulations do not allow phased permitting; therefore, an application for the entire project must be submitted and approved before any construction. It is still possible to phase the other applications because the NESHAPs application does not require the same level of detail of information for approval.

\subsubsection{Recomimended Approach}

The recommended strategy for WFD activities, is to prepare, revise, and/or extend existing air permit applications or approvals as necessary. A detailed summary for the projects that have approvals is provided in Tables 5-1 through 5-4. Status of the projects is as follows: 
HNF-2401, Rev. 0

W-058

Project W-058, Cross-Site Transfer System, approvals are in place.

\section{W-151 and W-030}

Project W-151 101-AZ Retrieval Systems and W-030 Ventilation Upgrades, approvals are in place. However, it is necessary to revise the NOC using a different ventilation flowrate and data for the source term.

\section{W-211}

Project W-211, Initial Tank Retrieval Systems (ITRS), scope is to install a waste retrieval system in 10 DSTs (241-AP-102, -AP-104, -AN-103, -AN-104, -AN-105, -AN-107, -AW-101, -AY-102, -AZ-102, and $-S Y-102$ ) between now and the year 2006. Because of the extended installation schedules and unknowns concerning specific activities/designs at each tank, it was determined to submit NOCs as information becomes available. The first NOC approved for Project W-211 (241-SY-102) provided the general descriptions of a mixer pump, its installation, and the mixing/retrieving process. The intention is that future NOCs submitted under W-211 would reference its descriptions, or other previously approved W-211 approved NOCs, and provide specific information as needed to complete the approval process for each tank or group of tanks.

\section{$\underline{W-320}$}

Project W-320, Tank 241-C-106 Sluicing approvals, are in place. However, it has been determined to submit two additional NOCs for retrieving the remaining heel. The permitting strategy for retrieving the heel from tank 241-C-106 is discussed in detail in HNF-SD-HTI-EV-001, Revision 1.

\section{$\underline{W-314}$}

Air permitting applications have been prepared and submitted for project W-314 LAW and HLW transfer systems supporting WFD. A NOC covering the initial project W-314 activities has been approved by the responsible agencies. An approval condition established by WDOH includes limitations associated with the control of potential radioactive air emissions from project W-314 construction activities.

Subsequent tank farm infrastructure upgrades are scheduled to continue through the year 2007 under project W-314, some of which may also support WFD. The need for air permitting documentation will be assessed as these project W-314 activities proceed, and NOCs will be prepared and submitted as needed for regulatory agency approval before beginning construction.

\section{$\underline{\text { W-519 }}$}

The function of project W-519 is to provide infrastructure (e.g., piping, electricity, water) for the private vendors. Installing the needed infrastructure may disturb contaminated soils; which may require air permitting. The current schedule for project W-519 is for infrastructure work to begin in FY 1998 and continue into FY 2001. As recommended in the next section, air permitting applications/approvals need approximately 9 months from start to finish. 


\section{$\underline{\mathrm{W}-454}$}

Project W-454 replaces and adds new jumper manifolds to the AW-A and AW-B valve pits. The schedule for project W-454 is not established yet, and as recommended in the next section, air permitting applications/approvals need approximately 9 months from start to finish.

\section{Miscellaneous Projects}

The recommended strategy for these projects is to secure the air permits (for applicable activities and affected facilities) before construction. It is expected that an application for approval to construct will be submitted for WAC 246-247, 40 CFR 61 Subpart H (NESHAPs), and WAC 173-460 (TAPs). It is assumed that the activities will not result in emissions exceeding significance levels for any criteria pollutants under the PSD program. Additionally, installation of BARCT may be required by WAC 246-247 and T-BACT may be required by the TAPs program.

Project W-TBD1 provides sludge washing capability in AZ-101 and four additional DST retrieval and transfer systems. The schedule indicates sludge washing capabilities for AZ-101 are to be in place FY 2001. Currently, air permitting applications must be prepared. As recommended in the next section, air permitting applications/approvals need approximately 9 months from start to finish.

Project W-TBD2 will provide additional retrieval and transfer capabilities to the DST system which are not currently included in other projects. The schedule for this project includes the period from FY 1998 through FY 2007. Air reviews and permit applications have not yet been performed for this project, and cannot begin until more definitive information about the types and extent of expected facility and operating changes. As recommended in the next section, air permit applications/approvals need about 9 months, start to finish, to complete.

Although numerous projects supporting WFD have been established and are underway, TWRS continues to identify a variety of facility improvements (e.g., pipeline replacements, valve pit upgrades) that are not currently covered by any known/planned projects, yet which are necessary for successful Phase 1B WFD. Project W-XXX provides the system analysis and conceptual engineering necessary to identify and describe the remaining WFD-related systems, structures, and components. Air reviews and permit support have not been determined for this project yet, but specification of air compliance issues (and integration with construction and operation schedules) will occur as project needs are identified.

\subsection{PRELIMINARY SCHEDULE AND COST ESTIMATE}

It will take approximately 9 months (assuming that all required information and data are available for submittal) to prepare a permit application and receive regulatory approval. If more than one application is required, the application(s) can (and should) be prepared and submitted in parallel to shorten the overall time it takes to receive all applicable approvals. Expedient preparation of an application depends on timely receipt of the descriptive information and the emissions estimate. An expanded schedule might be required if there are data collection needs. A generic permit application schedule is as follows:

Prepare emissions estimate/calculations

(1 month minimum) 
HNF-2401, Rev. 0

Prepare permit application

draft application -1.5 months

internal review -2 weeks

resolve/incorporate comments -1 month

DOE-RL review

review - 1 month

resolve/incorporate comments - 1 month (internal)

Regulator 30-day completeness notification - 1 month (regulator)

Regulator review and approval

3 months

A preliminary cost estimate of $\$ 43,000$ has been developed for the activities associated with securing one air permit and approvals. If BARCT and T-BACT assessments need to be prepared, each assessment might cost an additional $\$ 25,000$ (approximate). 
HNF-2401, Rev. 0

Table 5-1. Air Approvals for Project W-058, Cross-Site Transfer System.

\begin{tabular}{|l|l|l|l|l|}
\hline Agency & Company & Description & Permit Number & Date \\
\hline EPA & LMHC & $\begin{array}{l}\text { Approval for } \\
\text { excavating and } \\
\text { backfilling support }\end{array}$ & Letter & June 19,1997 \\
\hline WDOH & LMHC & TBD & $\begin{array}{l}\text { Routine technical } \\
\text { assistance mtg }\end{array}$ & TBD \\
\hline
\end{tabular}


Table 5-2. Air Approvals and Documentation for Project W-151,

Tank AZ-101 Waste Retrieval System,

and Project W-030, Tank Farm Ventilation Upgrade. (sheet lof 2)

\begin{tabular}{|c|c|c|c|c|}
\hline Agency & Project & Description & $\begin{array}{l}\text { Permit } \\
\text { Number }\end{array}$ & Date \\
\hline Ecology & $\begin{array}{l}\text { AY/AZ } \\
\text { Ventilation } \\
\text { Upgrades }\end{array}$ & $\begin{array}{l}\text { Mr. King was concerned about the } \\
\text { ventilation upgrades at AY/AZ requiring } \\
\text { Ecology approval. He reminded the Site that } \\
\text { Ecology was to be notified of all } \\
\text { modification activities. }\end{array}$ & N/A & $04 / 21 / 92$ \\
\hline Ecology & $\begin{array}{l}\text { AY/AZ } \\
\text { Ventilation } \\
\text { Upgrades }\end{array}$ & $\begin{array}{l}\text { Mr. King wrote to notify Hanford that any } \\
\text { AY/AZ ventilation system upgrades would } \\
\text { need a NOC, even if the modification results } \\
\text { in a decrease in toxic air pollutants } \\
\text { emissions. }\end{array}$ & Letter & $05 / 21 / 92$ \\
\hline EPA & $\begin{array}{l}\text { AY/AZ } \\
\text { Ventilation } \\
\text { Upgrades }\end{array}$ & $\begin{array}{l}\text { Request to modify the existing ventilation } \\
\text { system and install mixer pumps in AZ-101. }\end{array}$ & Letter & $03 / 15 / 94$ \\
\hline WDOH & $\begin{array}{l}\text { AY/AZ } \\
\text { Ventilation } \\
\text { Upgrades }\end{array}$ & $\begin{array}{l}\text { Request to modify the existing ventilation } \\
\text { system and install mixer pumps in AZ-101. }\end{array}$ & AIR 94-502 & $05 / 05 / 94$ \\
\hline WDOH & $\begin{array}{c}\text { Guzzler } \\
\text { 241AY/AZ }\end{array}$ & $\begin{array}{l}\text { Approval to use guzzler for } \mathrm{AY} / \mathrm{AZ} \\
\text { excavation. }\end{array}$ & Meeting & $05 / 14 / 96$ \\
\hline EPA. & $\begin{array}{l}\text { Guzzler } \\
241 \mathrm{AY} / \mathrm{AZ}\end{array}$ & $\begin{array}{l}\text { Request to use guzzzler for } \mathrm{AY} / \mathrm{AZ} \\
\text { excavation. WDOH approval received in } \\
\text { routine meeting. }\end{array}$ & Letter & $07 / 03 / 96$ \\
\hline WDOH & 241AY/AZ & $\begin{array}{l}\text { Request to modify NOC conditions of } \\
\text { original approvals (tritium and iodine-129) }\end{array}$ & AIR $96-702$ & $07 / 10 / 96$ \\
\hline EPA & 241AY/AZ & $\begin{array}{l}\text { Request to modify NOC conditions of } \\
\text { original approvals (tritium and iodine-129) }\end{array}$ & Letter & $09 / 03 / 96$ \\
\hline WDOH & 241AY/AZ & $\begin{array}{l}\text { Modification of NOC and approval to } \\
\text { construct monitoring and mixer pump } \\
\text { installation and operation using existing } \\
\text { ventilation system. }\end{array}$ & AIR 96-705 & $07 / 11 / 96$ \\
\hline EPA & 241AY/AZ & $\begin{array}{l}\text { Modification of NOC and approval to } \\
\text { construct monitoring and mixer pump } \\
\text { installation and operation using existing } \\
\text { ventilation system. }\end{array}$ & In Process & \\
\hline WDOH & 241AY/AZ & $\begin{array}{l}\text { Approval of a 4-month extension to original } \\
\text { 4-month extension (expired } 11 / 11 / 96 \text { ) for } \\
\text { the W-151 mixer pump operational test. }\end{array}$ & Meeting & $11 / 12 / 96$ \\
\hline
\end{tabular}


Table 5-2. Air Approvals and Documentation for Project W-151, Tank AZ-101 Waste Retrieval System, and Project W-030, Tank Farm Ventilation Upgrade. (sheet 2of 2)

\begin{tabular}{|c|c|c|c|c|}
\hline Agency & Project & Description & $\begin{array}{l}\text { Permit } \\
\text { Number }\end{array}$ & Date \\
\hline WDOH & 241AY/AZ & $\begin{array}{l}\text { Approval for operational test of mixer } \\
\text { pumps using the existing ventilation system. } \\
\text { The approval grants extension of the } \\
\text { approval through Nov. } 11,1997 \text {. }\end{array}$ & Meeting & $02 / 11 / 97$ \\
\hline EPA & 241AY/AZ & $\begin{array}{l}\text { Approval for operational test of mixer } \\
\text { pumps using the existing ventilation system. } \\
\text { The approval grants extension of the } \\
\text { approval through Nov. } 11,1997 \text {. }\end{array}$ & Letter & $03 / 20 / 97$ \\
\hline EPA & 241AY/AZ & $\begin{array}{l}\text { Modification of NOC and approval to } \\
\text { construct monitoring and mixer pump } \\
\text { installation and operation. }\end{array}$ & In process & \\
\hline Ecology & 241AY/AZ & $\begin{array}{l}\text { Request to modify NOC condition of original } \\
\text { approvals, specifically to modify VOC } \\
\text { emission limits and request approval of } \\
\text { alternative test method. Relief from Cond. } 1 \\
\text { in NOC } 94-07 \text {. }\end{array}$ & In process & \\
\hline Ecology & $\begin{array}{l}\text { Mixer Pump } \\
\text { Testing in } \\
\text { Tank } \\
\text { 241-AZ-101 }\end{array}$ & $\begin{array}{l}\text { Requested to modify the VOC emission limit } \\
\text { to } 50 \text { parts per million (by volume), } \\
\text { measured as carbon, use method } 25 \mathrm{~A} \text { for } \\
\text { VOC emission testing with an accuracy } \\
\text { deviation, and measure ammonia using } \\
\text { dragar tubes. Ref. NOC } 94-07 \text {. }\end{array}$ & In process & \\
\hline
\end{tabular}


HNF-2401, Rev. 0

Table 5-3. Air Approvals for Project W-320, Tank C-106 Sluicing.

\begin{tabular}{|c|c|c|c|c|}
\hline Agency & Project & Description & $\begin{array}{l}\text { Permit } \\
\text { Number }\end{array}$ & Date \\
\hline EPA & $\begin{array}{l}\mathrm{C}-106 \\
\text { Sluicing } \mathrm{CO}_{2} \\
\text { Decon }\end{array}$ & $\begin{array}{l}\text { Decontamination activities will use } \\
\text { pelletized } \mathrm{CO}_{2} \text { to remove radiation surface } \\
\text { contamination from pump pits and removed } \\
\text { equipment at tank. }\end{array}$ & Letter & $12 / 07 / 93$ \\
\hline WDOH & $\begin{array}{l}\mathrm{C}-106 \\
\text { Sluicing } \mathrm{CO}_{2} \\
\text { Decon }\end{array}$ & $\begin{array}{l}\text { Decontamination activities will use } \\
\text { pelletized } \mathrm{CO}_{2} \text { to remove radiation surface } \\
\text { contamination from pump pits and removed } \\
\text { equipment at tank. }\end{array}$ & Air $94-108$ & $01 / 31 / 94$ \\
\hline WDOH & $\begin{array}{l}\text { C-106 } \\
\text { Sluicing } \\
\text {-Phase I }\end{array}$ & $\begin{array}{l}\text { Requested to construct a waste retrieval } \\
\text { sluicing system to remove the sludge }\end{array}$ & Air 94-214 & $02 / 08 / 94$ \\
\hline Ecology & $\begin{array}{l}\text { C-106 } \\
\text { Sluicing } \\
\text { Phase I }\end{array}$ & $\begin{array}{l}\text { Letter to Ecology informing them the Phase I } \\
\text { activities associated with C- } 106 \text { sluicing was } \\
\text { not a new or modified source requiring } \\
\text { Ecology's prior approval. }\end{array}$ & N/A & $02 / 20 / 94$ \\
\hline EPA & $\begin{array}{l}\text { C-106 } \\
\text { Sluicing } \\
\text {-Phase I }\end{array}$ & $\begin{array}{l}\text { Requested to construct a waste retrieval } \\
\text { sluicing system to remove the sludge. }\end{array}$ & Letter & $02 / 23 / 94$ \\
\hline WDOH & $\begin{array}{l}\text { C-106 } \\
\text { Sluicing, } \\
\text { Phase II }\end{array}$ & $\begin{array}{l}\text { Radioactive Air } \\
\text { Emissions NOC for Phase II. }\end{array}$ & Air 95-712 & $07 / 31 / 95$ \\
\hline Ecology & $\begin{array}{l}\text { C-106 } \\
\text { Sluicing, } \\
\text { Phase II }\end{array}$ & $\begin{array}{l}\text { Nonradioactive Air Emissions for } \\
\text { Phase II of Project W-320. }\end{array}$ & $\begin{array}{l}\text { NWP 95(7) } \\
\text { C-106 }\end{array}$ & $10 / 06 / 95$ \\
\hline
\end{tabular}


HNF-2401, Rev. 0

Table 5-4. Air Approvals for Project W-211, Initial Tank Retrieval System.

\begin{tabular}{|c|c|l|c|c|}
\hline Agency & Project & Description & Permit Number & Date \\
\hline EPA & $\begin{array}{c}\text { 102-SY Mixer } \\
\text { Pumps }\end{array}$ & $\begin{array}{l}\text { Request to install } \\
\text { mixer pumps in } \\
\text { tank 102-SY }\end{array}$ & Letter & Air 96-902 \\
\hline WDOH & $\begin{array}{c}\text { 102-SY Mixer } \\
\text { Pumps }\end{array}$ & $\begin{array}{l}\text { Request to install } \\
\text { mixer pumps in } \\
\text { tank 102-SY }\end{array}$ & $09 / 11 / 96$ \\
\hline
\end{tabular}


HNF-2401, Rev. 0

This page intentionally left blank. 
HNF-2401, Rev. 0

\subsection{RADIATION PROTECTION STANDARDS/MONITORING}

DOE Orders 5400.1, General Environmental Protection Program, and 5400.5, Radiation Protection of the Public and the Environment, establish standards and requirements that must be followed to protect members of the public and environment against undue risk from radiation. Additional requirements for radioactive and mixed waste management are found in DOE Orders 5820.2A.

\subsection{SUMMARY OF KEY REQUIREMENTS AND APPROVAL PROCESS}

DOE Order 5400.1 requires a written environmental monitoring plan (EMP) for each site, facility, or process that uses, generates, releases, or manages significant pollutants or hazardous materials. The EMP must include the rationale and design criteria for the monitoring program, as well as describe the extent and frequency of the monitoring. The EMP also must contain quality assurance (QA) requirements, program implementation procedures, directions for preparation and implementation of reports, and directions for identification and discussion of effluent monitoring and environmental surveillance. An EMP is prepared for all DOE activities on the Hanford Site and is updated every 3 years to include new or modified facilities and projects (DOE/RL-91-50).

The effluent monitoring portion of the plan must verify compliance with applicable regulations and DOE Orders. For major facilities on the Hanford Site, this is documented in the form of specific facility effluent monitoring plans (FEMP). There are two thresholds used to determine the need for a FEMP: (1) if the total projected dose to a member of the public from radionuclides exceeds $0.1 \mathrm{mrem}$ from any one discharge point, or (2) if any one regulated material discharged from a facility exceeds $100 \%$ of a reportable quantity (RQ) or a permitted quantity, a FEMP is required for that facility. Preparation of a FEMP assesses effluent monitoring systems and evaluates whether these systems are adequate to ensure the public health and safety as specified in applicable federal, state, and local requirements. The FEMP will ensure long-range integrity of the effluent monitoring systems by requiring an update whenever a new process or operation introduces new hazardous materials or significant radioactive materials. This document must be reviewed annually even if there are no operational changes, and it must be updated, at a minimum, every 3 years.

\subsubsection{Routine Environmental Monitoring}

DOE Orders 5400.1 and 5400.5 require that baseline data be obtained before the start of a project (pre-operational monitoring), and that periodic (near facility monitoring) be performed to determine if the environment is being affected. The basic monitoring required includes the following:

- Radionuclide concentrations in the ambient air

- Background radiation levels at the project site and in surrounding areas

- Radionuclides present in flora, fauna, soil, wildlife, and water.

\subsubsection{EPA Requirements for Radiation Protection}

Subpart H, "National Emission Standards for Emissions of Radionuclides Other Than Radon from Department of Energy Facilities", (40 CFR 61) establishes exposure limits and monitoring requirements. The exposure limits, for members of the public, from radiomaclide emissions is an effective dose equivalent 
(EDE) not to exceed 10 mrem per year. Compliance with this standard is measured by calculating the highest EDE where a person resides or abides using an EPA-approved method.

Emissions of radionuclides must be measured at all release points that have a potential to discharge radionuclides into the air in quantities that could cause an EDE in excess of $1 \%$ of the standard. If the EDE caused by all emissions is less than $1 \%$ of the standard, the facility is exempt from the EPA monitoring requirements. All radionuclides that could contribute greater than $10 \%$ of the potential EDE for a release point are measured individually. For other release points that have a potential to release radionuclides into the air, periodic confirmatory measurements are made to verify low emissions.

\subsubsection{Radioactive Waste Management}

The DOE Order 5820.2A, Radioactive Waste Management establishes policies, guidelines, and minimum requirements by which the DOE manages its radioactive and mixed waste and contaminated facilities. Radioactive waste (e.g., mixed, high-level, transuranic, etc.) generated by DOE operations is to be safely stored, treated, and disposed of according to the requirements set forth in DOE Order 5820.2A. Radiation dose limits received by members of the public as a result of the management and storage of spent nuclear fuel, high-level, or transuranic wastes at any DOE disposal facility are not to exceed the limits described in 40 CFR 191, Subpart A(b).

\subsubsection{DOE Order 5400.1 Environmental Compliance Documents}

The following documents were prepared to comply with the requirements for environmental monitoring at DOE facilities. The current effort is primarily updating these plans as required to reflect cleanup activities on the Hanford Site and to reflect any changes in the monitoring programs.

DOE/RL- 91-50, Environmental Monitoring Plan (EMP) United States Department of Energy Richland Operations Office, Rev. 2, 1997, U.S. Department of Energy, Richland Operations Office, Richland, Washington (update every 3 years, next due November 7, 2000).

WHC-EP-0446-2. Quality Assurance Project Plan for Facility Effluent Monitoring Plan Activities (QAPP). Westinghouse Hanford Company, Richland, Washington, October 1994.

WHC-EP-0438. A Guide for Preparing Hanford Site Facility Effluent Monitoring Plans. Westinghouse Hanford Company, Richland, Washington. July 1991.

HNF-MR-0535, Integration Plan for Environmental Monitoring (with the exception of groundwater monitoring), Fluor Daniel Hanford, Inc., March 1997.

\subsection{APPLICABILITY TO WASTE FEED DELIVERY ACTIONS}

A FEMP determination is performed to assess the need to prepare a FEMP. The radioactive and chemical source terms must be reviewed, and if one of the two thresholds can be exceeded, a FEMP must be prepared. If not, $a$ one page form is sufficient to document the determination. The sitewide EMP will be updated automatically; no facility specific effort is required. 
Most of the FDH team environmental monitoring activities are performed by Waste Management Federal Services of Hanford (WMH) and Waste Management Northwest (WMNW). Policy and integration activities are the responsibility of FDH. The Hanford Site Integrated Plan for Environmental Monitoring (HNF-MR-0535) was developed and agreed to by all Hanford Site contractors [Pacific Northwest National Laboratory (PNNL), Bechtel Hanford, Inc. (BHI), and the FDH team]. The monitoring of effluents and the enviromment is documented formally each year, and all TWRS activities need to be included as appropriate.

The following paragraphs briefly describe each effluent or environmental report that requires data from Hanford Site facilities and projects. The regulatory driver is cited for each report. These reports represent the final products of the Hanford Site's Integration Plan for Environmental Monitoring (HNF-MR-0535). Although the reports typically are published annually, the monitoring and collection of meaningful data requires routine interaction with the other onsite contractors to ensure activities are integrated without duplication of effort.

\section{Environmental Releases Report}

This annual report, issued by WMH, presents data for radioactive and nonradioactive substances released into the environment during each calendar-year (CY) from Hanford Site facilities managed by the FDH team and BHI in accordance with DOE Order 5400.1. The report is issued by July 31 following the most recently completed calendar year.

\section{Radionuclide Air Emissions Report for the Hanford Site}

The radionuclide air emissions report is due to the EPA by June 30 of each year following the year being reported in accordance with 40 CFR 61, Subpart $H$. The report is prepared by WMH for DOE-RL and contains data on radionuclides emitted to the atmosphere from Hanford Site facilities managed by PNNL, BHI, and the FDH team.

\section{Washington State Department of Ecology Request for Nonradioactive Emission Inventory Information}

WMH annually transmits a report on nonradioactive air emissions to DOE-RL for submittal to the local office of Ecology, Nuclear Waste Program in accordance with WAC 173-400-105. The report is due April 15 following the year being reported.

\section{Hanford Site Environmental Report}

PNNL annually issues an environmental report encompassing the entire Hanford Site in accordance with DOE Order 5400.1, which is due August 1 of each year. WMH has been assigned responsibility for writing and updating some sections of the report, principally the effluent section. Generally, these sections deal with environmental releases of radionuclides in air emissions and liquid effluents; releases of nonradioactive hazardous substances, unplanned environmental releases of significance, inventories of chemicals, near-facility environmental surveillance activities, and environmental cleanup missions.

\subsection{SATISFYING APPLICABLE RADIATION PROTECTION REQUIREMENTS}

The following sections describe the alternatives available for satisfying appropriate radiation protection requirements and the recommended approach for the WFD system environmental planning basis. 


\subsubsection{Available Alternatives}

The three alternatives available for this project are as follows: (1) gather the required information specifically for this project, (2) use information gathered by TWRS and routine monitoring of the Hanford Site, and (3) use routine monitoring data for the Hanford Site supplemented by project-specific data related to the location of new specific WFD projects outside of the current established thresholds.

1. Gathering the data specifically for WFD activities project would duplicate a considerable amount of monitoring work routinely performed on the Hanford Site particularly for TWRS activities. Alternative 1 is judged to be the most expensive alternative and has the longest schedule.

2. The use of existing data for the baseline would limit efforts to ongoing monitoring. The ongoing monitoring could be accomplished by use of site programs and the specific monitoring established for TWRS. It is not expected that the WFD activities will require monitoring beyond that done by the routine site programs.

3. Make use of routine monitoring data for the Hanford Site supplemented by data specific to WFD. Because very little data can be separated from the WFD and TWRS, this option would not appear viable.

\subsubsection{Recommended Approach}

The recommended approach is to use Alternative 2. Baseline data are required for this project; however, no specific action is needed because the same data are required for TWRS or as part of other routine Hanford Site monitoring.

\subsection{PRELIMINARY COST AND SCHEDULE ESTIMATES}

No additional costs are currently anticipated under the current WFD planning basis. However, costs might be incurred by the need to evaluate new project scope for threshold monitoring limits. If outside threshold activities are identified, cost and schedule estimates would be made on a case-by-case basis. 
HNF-2401, Rev. 0

\subsection{MISCELLANEOUS ASSESSMENTS, PERMITS, AND APPROVALS}

In addition to the major regulatory programs, several miscellaneous assessments, permits, and approvals are addressed in the following sections.

\subsection{SUMMARY OF KEY REQUIREMENTS AND PROCESSES}

The following reviews and approvals are required before construction or excavation activities begin.

\subsubsection{Cultural/Ecological Resource Review}

A cultural review shall be performed for any project involving demolition, modification, or deactivation of a potentially historic facility or structure (36 CFR 800). The CERR must be made before initiating any external surface-disturbing activities onsite, or if any modifications are planned for any facility with the potential for inclusion on the National Register of Historic Places. The request form to perform this assessment is located on the HLAN, under Site Forms, [A-6001-930, "Request for Cultural/Historic Resources Review"]. The regulatory agency is DOE-RL.

A site survey should be performed to identify: Any plant or animal species protected under the Endangered Species Act; candidates for such protection; species listed as threatened, endangered, candidate, sensitive, or monitored by the state of Washington; and species protected under the Migratory Bird Treaty Act. Also assessed is whether the planned activities have the potential to disturb any priority habitats and/or species identified in the survey. The request form to perform this review (along with the CERR) is macro GEF271. This review also fulfills the NEPA ecological/biological review requirement.

NOTE: This section also applies to: taking, possession, transportation, sale, purchase/barter, export, import of special status plants and animals (both living and dead). It includes removal/remediation action, corrective action, decontamination/decommissioning (D\&D) activities, and project construction activity.

\subsubsection{Site Location}

Any new facility must receive a landlord site location review, coordinated by Dyncorp/Site and Land Use Planning organization. This review is a Hanford best management practice. It offers an opportunity during the early planning stages to identify unusual or uncertain compliance, safety or operations issues; it covers similar aspects as the alternatives review under NEPA (Environmental Impact Statement, or Environmental Assessment).

A siting evaluation should be made of the proposed routing for all underground piping, pits, pads, and support structures within WFD. A review for intrusion into radiation control areas, underground contamination areas and buried tanks should also be made to avoid any unanticipated exposures. Data from the site location review should be kept for reference use by the excavation permit authority. 


\subsubsection{Excavation Permit}

An excavation permit is required before initiating any potential surface-disturbing onsite activities (36 CFR 800). The request form to obtain this permit is located on the HLAN, under Site Forms, [A-7400-373, "Hanford Excavation Permit"]. The facility Environmental Compliance Officer (ECO) may review and approve excavation permits prior to excavation begins, to ensure that all CERR issues are met.

Detailed information needed for the excavation permits under WFD will be the responsibility of each individual supporting project. Data from the site location review should be examined during the approval of the excavation permits.

\subsubsection{American Indian Tribal Government Agreements}

American Indian Tribal Governments have a special and unique legal relationship with the US Federal Government and its agencies (DOE 1230.2). These are defined in numerous treaties, statues, historical precedents, and the US Constitution. In addition, the state of Washington has agreements respecting current and future use of the lands surrounding the Hanford Site. All actions on the Hanford Site which may impact these agreements must be approved by the DOE-RL office for native American interests. The Cultural Resource Review will be the mechanism for identifying any such potential impacts.

It is assumed that all actions included under the WFD project will occur inside or within 150 meters of the 200 East/200 West tank farm boundaries. The WFD areas have an existing cultural review (initially Aug 16, 1994; updated annually). No further review should be needed.

\subsubsection{Endangered Species Act Compliance}

A site assessment should be made to determine whether any planned activities have the potential to disturb any habitat used by wildlife before construction or habitat modification (50 CFR 402.6). The regulatory agency is the State or Federal Fish and Wildlife Service. For onsite construction, a biological survey should be performed.

\subsubsection{Pre-operational Monitoring of Facilities, Sites, and Operations}

A pre-operational environmental study shall be conducted before startup of a site, facility, or process that has the potential for significant adverse environmental impact (DOE Order 5400.1). This study should begin not less than 1 year (preferably 2 years) before startup, so seasonal changes can be evaluated. This study precedes the conceptual design report and can include data acquired in the site selection process, excavation permit process, and NEPA/SEPA process. For more information, refer to the environmental compliance procedures, HNF-PRO-453, HNF-PRO-456, and HNF-PRO-457.

It is assumed that each individual supporting project will request a pre-operational survey of the proposed usage location, as soon as the site evaluation review is complete. 
HNF-2401, Rev. 0

\subsection{APPLICABILITY TO WASTE FEED DELIVERY ACTIONS}

The proposed action, conduct of WFD, includes upgrading and constructing waste feed transfer lines, transferring waste from tanks to privately operated waste immobilization facilities, and related supporting activities. Many of these proposed actions will require permits and other approvals from environmental compliance officers or line managers for onsite construction operations. As documented in Appendix A, WFD is considered to require the appropriate miscellaneous permits and assessments before initiating excavation or construction activities.

\subsection{SATISFYING APPLICABLE REQUIREMENTS}

The cultural resource review and endangered species compliance reviews have been addressed in 'blanket' reviews for TWRS. The WFD system project should fall within the area identified in the "Cultural Resources Exemption of the Tank Farm Areas" (PNL 1994) evaluation dated August 16, 1994 submitted to the DOE-RI and amended annually and within the "1995 Blanket Biological Review of the 200 West and 200 East Tank Farms, 200 West and East Areas" as amended annually in April (PNNL 1997). The regulatory strategy is that the 'blanket' reviews will encompass the activities within the 200 East Tank Farm boundary and a request for a review of the WFD relative to the existing survey reports, as amended, will be required before securing an excavation permit.

\subsection{PRELIMINARY COST AND SCHEDULE ESTIMATES}

It is expected that most of the assessments, permits and approvals noted above are already being completed under the scope of existing programs and activities for TWRS and/or the Hanford Site. The scope, costs, and schedules for these ongoing programs have already been established, and are not likely to be significantly affected by activities specific to WFD. What incremental or additional efforts may occur (e.g., development of excavation permit, cultural resource walkdown of pipeline corridor) are expected to be minimal (e.g., less than $\$ 5,000$, less than two weeks) in most cases. Thus, development of cost and schedule estimates has been deferred at this time. Estimates can be prepared and incorporated in Appendix C later, if necessary, as project-specific needs are identified. 
HNF-2401, Rev. 0

This page intentionally left blank. 
HNF-2401, Rev. 0

\subsection{REFERENCES}

DOE/EIS-0189, Final Environmental Impact Statement for the Tank Waste Remediation System, U.S. Department of Energy, Richland Operations Office, Washington.

DOE/EIS-0212, Safe Interim Storage of Hanford Tank Wastes Environmental Impact Statement, U.S. Department of Energy, Richland Operations Office, Richland, Washington.

DOE/EIS-0245-F, Final Environmental Impact Statement: Management of Spent Nuclear Fuel from the $K$-Basins at the Hanford Site, Richland, Washington, U.S. Department of Energy, Richland Operations Office, Richland, Washington.

DOE Order 5400.1, General Environmental Protection Program.

DOE Order 5400.5, Radiation Protection of the Public and the Environment.

DOE Order 5820.2A, Radioactive Waste Management.

DOE-RL, 1996a, BNFL, Inc., Privatization Contract, DE-AC06-96RL13308, U.S. Department of Energy, Richland Operations Office, Richland, Washington.

DOE-RL, 1996b, Lockheed Martin Advanced Environmental Systems, Inc., Privatization Contract, DE-AC06-96RL13309, U.S. Department of Energy, Richland Operations Office, Richland, Washington

DOE/RL-91-28, Hanford Facility Dangerous Waste Permit Application, General Information Portion, U.S. Department of Energy, Richland Operations Office, Richland, Washington.

DOE/RL-91-50, Environmental Monitoring Plan United States Department of Energy Richland Operations Office, Rev. 2, 1997, U.S. Department of Energy, Richland Operations Office, Richland, Washington.

Ecology, EPA, and DOE-RL, 1996, Hanford Federal Facility Agreement and Consent Order, Washington State Department of Ecology, U.S. Environmental Protection Agency, U.S. Department of Energy, Richland Operations Office, Olympia, Washington, amended periodically.

HNF-1751, Immobilized High-Level Waste Storage Subproject Plan, Fluor Daniel Hanford, Inc., Richland, Washington.

HNF-1773, Tank Waste Remediation System Environmental Program Plan, Rev. 0, 1998, Fhor Daniel Hanford, Inc., Richland, Washington.

HNF-1939, Waste Feed Delivery Technical Basis Document, Rev. 0 - DRAFT, prepared by Numatec Hanford Corporation for Fluor Daniel Hanford, Inc., Richland, Washington.

HNF-2019, Tank Waste Remediation System Retrieval and Disposal Mission Readiness-to-Proceed Memorandum, Rev. 1, 1998, Fluor Daniel Hanford, Inc., Richland, Washington. 
HNF-2401, Rev. 0

HNF-MR-0535, Integration Plan for Environmental Monitoring, Rev. 0, 1997, Fluor Daniel Hanford, Inc., Richland, Washington.

HNF-PRO-452, NEPA, SEPA, Cultural and Natural Resources, Fluor Daniel Hanford, Inc., Richland, Washington.

HNF-SD-HTI-EV-001-1, Permitting Plan for Hanford Tank Initiative, March 1998, Fluor Daniel Hanford, Inc., Richland, Washington.

HNF-SD-WM-MAR-008, Tank Waste Remediation System Mission Analysis Report, Rev. 3, 1998, prepared by Lockheed Martin Hanford Corporation for Fluor Daniel Hanford, Inc., Richland, Washington.

HNF-SD-WM-SP-012, Tank Waste Remediation System Operation and Utilization Plan, Rev. 0, 1997 , Volumes I and II, prepared by Numatec Hanford Corporation for Fluor Daniel Hanford, Inc., Richland, Washington.

HNF-SP-0903, HNF-SP-0903, NEPA Source Guide for the Hanford Site, Fluor Daniel Hanford, Inc., Richland, Washington

PNL, 1994, letter from M.E. Crist, Pacific Northwest Laboratories, to W.B. Bancroft, Westinghouse Hanford Company, "Cultural Resources Exemption of the Tank Farm Areas", August 16, 1994.

PNNL, 1997, letter from C.A. Brandt, Pacific Northwest National Laboratory, to Randy K. P'Pool, Lockheed Martin Hanford Corp., "Blanket Biological Review for the Tank Farm Facilities, $200 \mathrm{E}$ and 200 W Areas, \#97-200-047", April 15, 1997.

60 FR 61687, Record of Decision for Safe Interim Storage of Hanford Tank Wastes, Hanford Site, Richland, Washington.

62 FR 8693, Record of Decision for Tank Waste Remediation System, Hanford Site, Richland, Washington. 
HNF-2401, Rev. 0

\section{APPENDIX A}

ENVIRONMENTAL REQUIREMENTS CHECKLIST FOR

WASTE FEED DELIVERY 
HNF-2401, Rev. 0

This page intentionally left blank. 


\section{SCOPE OF WORK/ENVIRONMENTAL SUMMARY FOR TANK WASTE REMEDIATION SYSTEM - WASTE FEED DELIVERY PROJECT}

WFD will use phased implementation to demonstrate retrieval technologies and provide WFD to receiver tanks and waste immobilization facilities. Phase 1 activities (development followed by demonstration) would last for approximately 10 years. Objectives of WFD under Phase 1 include the following:

- Retrieval of current and future tank waste from single-shell, double-shell, and miscellaneous underground storage tanks;

- Transfer of liquid waste to receiver tanks, and transfer of selected waste for special processing directly to the high-level waste immobilization facility;

- Acceptance of a portion of the sludge, strontium, and transuranic waste from separations processes to the double-shell tanks for future retrieval and treatment during Phase 2;

- Delivery of waste feed to the privately owned and operated waste immobilization facilities.

The following defined projects support the accomplishment of WFD:

W-030, Aging Waste Ventilation Upgrades,

W-058, Cross-Site Transfer System Upgrade,

W-151, Tank AZ-101 Equipment Upgrades,

W-211, Initial Tank Retrieval System (equipment installations),

W-314, HLW \& LLW Transfer System,

W-320, Waste Retrieval from Tank C-106,

W-454, AW Tank Farm Pit Upgrades,

W-519, Privatization Infrastructure (FDH team interfaces).

There are several other projects being defined and established to support WFD. Most of the support projects involve some design/procurement effort, as well as operations, maintenance, training, monitoring, reporting, and other activities. The identified equipment has been determined to be an essential component of the overall WFD project covered by the existing NEPA documentation. Any environmental issues associated with the equipment procurement/design/fabrication/shipping will be identified during critical design reviews.

The next activity sequence will involve installation of the several systems, items, or components needed to support the overall operations under the WFD project. Environmental issues associated with installation include: breaking existing containment/confinement systems (tanks/piping/ancillary systems) and tie-ins for new equipment/systems. The associated safety equipment list, documents potential safety/environmental compliance issues. Project W-314, for instance, includes upgrades to the AN, AP, and AW DSTs ventilation and filtration systems. These compliance issues will be confirmed during permit preparation and critical reviews of installation work packages by the environmental oversight authority.

This activity has the potential for release of airborne emissions, currently in diffusive equilibrium in the $\operatorname{tank}(\mathrm{s})$ head space and ancillary systems. There also will be a second potential for generating additional airborne contamination because of equipment retrieval and installation tasks that penetrate/disturb the contained waste.

All waste intrusive tasks have the potential to generate airborne emissions, plus secondary solid waste (contaminated equipments and personal protective equipment/supplies). All such tasks will be subject to an ALARA review, before initiating work package tasks. All secondary waste will be controlled, designated, 
and dispositioned in accordance with existing onsite procedures. Following installation of required equipment/systems/components, a final configuration compliance review will be performed, under the control of the project environmental authority. This will be coordinated with the facility operational readiness review.

Demonstrations of the systems, equipment, and components will compose the final activity for Phase 1 of the WFD project. Phase 2 (long-term operation, decontamination/decommissioning requirements, plus closure) is not included in the scope of this checklist. Operation in some tanks might include low concentrations of air emissions, generation/disposition of liquid effluents, plus generation of solid secondary waste. Operation in other tanks will involve release of larger quantities of entrained gases, some of which might be toxic, some might be criteria pollutants, and some might be flammable. Controls will be developed to maintain permit compliance, and meet all ancillary environmental protection guidelines and agreements.

This checklist identifies the legal drivers and individual requirements that support the permitting/compliance strategy, whereas the WFD Permits and Approvals Plan identifies required permitting support activity by general legislative category. Issues and requirements identified in this checklist must be evaluated in detail by the technical specialists identified in the associated WFD project evaluations, for each of the narrative areas. A permitting and compliance strategy should be developed to meet all of the finalized requirements. Requirements identified in this checklist should be verified throughout the course of the WFD project, for compliance. 


\section{EXPLANATION OF ENVIRONMENTAL REQUIREMENTS AND NARRATIVE}

The following table identifies environmental permits, approvals, and/or requirements applicable to the project. Any "Yes" or "To Be Determined" answer in the applicability column will be further described in the narrative that follows the table. Some "No" answers might require special explanation and will have narrative associated with these. In this case, the words "See Text" will be stated in the applicability column. A contact person is identified at the end of each evaluation to answer questions and/or provide additional information regarding the specific regulation in question. If the contact cannot be reached, TWRS Environmental Compliance organization or WMH Environmental Management Services could be contacted to answer questions or to coordinate meetings with subject matter experts within the environmental area.

Environmental requirements are often subject to change, particularly as a project proceeds toward final design. The checklist represents a 'snapshot in time', which is usually based on preliminary planning data, using functional criteria. WMH Environmental Management Services recommends that the criteria identified in this checklist be re-evaluated after the final design is complete so that the appropriate data is included in the final permits.

Because the WFD project is a general 'umbrella' project, this checklist refers many issues to the several supporting projects that comprise the WFD. Many of the supporting projects are not completely defined, some are already in progress, and some projects, e.g., W-030 action to upgrade the ventilation system of the Aging Waste Facility, are scheduled to be completed in FY 1998. Where issues are not well-defined, the checklist uses TBD to indicate actions that will need further evaluation by the individual support projects. In all cases, as a project is ready to enter final design, a re-evaluated should be to ensure that all applicable requirements will be satisfied. 


\section{ABBREVIATIONS and ACRONYMS*}

ALARA
AOP
ARARs
BACT
BARCT
BCCAA
BFDHD
CAA
CDR
CERCLA

CERR

CFC

CFR

CRR

CX

DOE-HQ

DOE-RL

DNR

DNS

DST

EA

Ecology

EIS

EIS/ODIS

EPA

FDH

FR

FONSI

gpd

HCRL

HLAN

HLW

HPA

IB

IEU

ITRS

LAER

LDUA

MEI

mrem

MTF

MWC

NEPA

NESHAPS

NOC

NOI

NPDES

NSR as low as reasonably achievable

air operating permit

applicable or relevant and appropriate requirements

best available control technology

best available radionuclide control technology

Benton County Clean Air Authority

Benton-Franklin District Health Department

Clean Air Act of 1977

conceptual design report

Comprehensive Environmental Response, Compensation, and Liability

Act of 1980

Cultural/Ecological Resources Review

chlorofluorocarbons

Code of Federal Regulations

cultural resource review

categorical exclusion

U.S. Department of Energy-Headquarters

U.S. Department of Energy, Richland Operations Office

Department of Natural Resources

determination of non-significance (by Ecology)

double-shell tank

environmental assessment

Washington State Department of Ecology

environmental impact statement

effluent information system/onsite discharge information system

U.S. Environmental Protection Agency

Fluor Daniel Hanford, Inc.

Federal Register

finding of no significant impact

gallons per day

Hanford Cultural Resource Laboratory

Hanford Local Area Network

high-level waste

Hydraulic Projects Approval

information bulletin (not in current usage)

insignificant emission units

Initial Tank Retrieval System

lowest achievable emission rate

light duty utility arm

maximum exposed individual

millirem

memorandum-to-file (not in current usage)

municipal waste combustor

National Environmental Policy Act of 1969

National Emission Standards for Hazardous Air Pollutants

notice of construction

notice of intent

National Pollutant Discharge Elimination System

new source review 
PAA

PCB

PHMC

POC

PL

PNNL

PSD

RACT

RCRA

SEPA

SST

SWDP

TAPs

T-BACT

TEDE

T-RACT

Tri-Party Agreement (TPA)

TRU

TSCA

TSD

TWRS

UIC

USACE

UST

WAC

WDOH

$\mathrm{WMH}$
Price-Anderson Amendments (review)

polychlorinated biphenyl(s) (specially regulated substance)

Project Hanford Management Contract

point of contact

Public Law

Pacific Northwest National Laboratory

Prevention of Significant Deterioration

reasonably available control technology

Resource Conservation and Recovery Act of 1976

Washington State Environmental Policy Act of 1971

single-shell tank

State Waste Discharge Permit

toxic air pollutants

best available control technology for toxics

total effective dose equivalent

reasonably available control technology for toxics

Hanford Federal Facility Agreement and Consent Order

transuranic (material/elements/waste)

Toxic Substances Control Act of 1976

treatment, storage, and/or disposal

Tank Waste Remediation System

underground injection control

U.S. Army Corps of Engineers

underground storage tanks

Washington Administrative Code

Washington State Department of Health

Waste Management Federal Services of Hanford, Inc.

* Note: This list applies to the complete environmental compliance area and might not apply in full to individual checklists. 
SUMMARY CHECKLIST OF POTENTIAL PERMITS/APPROVALS/REQUIREMENTS

\begin{tabular}{|c|c|c|c|c|c|}
\hline $\begin{array}{l}\text { ENVIRONMENT- } \\
\text { MEDIA }\end{array}$ & $\begin{array}{l}\text { PERMIT, APPROVAL, } \\
\text { or REQUIREMENT }\end{array}$ & REGULATION(S) * & $\begin{array}{l}\text { REGULATORY } \\
\text { AGENCY }\end{array}$ & RESTRICTION & $\begin{array}{l}\text { APPLY? } \\
(\mathrm{Y} \text { or } \mathrm{N})\end{array}$ \\
\hline \multirow[t]{2}{*}{ NEPA } & NEPA Documentation & $\begin{array}{l}40 \text { CFR } 1500-1508 \\
10 \text { CFR } 1021 \\
\text { DOE Order } 451.1 \mathrm{~A}\end{array}$ & DOE & $\begin{array}{l}\text { Title II Design } \\
\text { (Projects), } \\
\text { Procurement }\end{array}$ & \\
\hline & Price Anderson Review & 10 CFR 835 & $\begin{array}{l}\text { DOE \& } \\
\text { FDH } \\
\text { Legal }\end{array}$ & $\begin{array}{l}\text { Operational Read- } \\
\text { iness }\end{array}$ & N \\
\hline SEPA & SEPA Documentation & WAC 197-11 & Ecology & $\begin{array}{l}\text { License, } \\
\text { Permit }\end{array}$ & \% \\
\hline $\begin{array}{l}\text { External Procure- } \\
\text { ment }\end{array}$ & NEPA 216 Process & 10 CFR 1021.216 & $\begin{array}{l}\text { FDH Procure- } \\
\text { ment \& DOE/RL }\end{array}$ & $\begin{array}{l}\text { Environmental Cri- } \\
\text { tique before external } \\
\text { contract is let. }\end{array}$ & No \\
\hline \multirow[t]{2}{*}{ CERCLA } & ARARs & 40 CFR 300.400 & EPA & Construction & $\mathrm{x}$ \\
\hline & $\begin{array}{l}\text { Model Toxics } \\
\text { Control Act } \\
\end{array}$ & WAC $173-340$ & Ecology & TPA cleanup & M \\
\hline \multirow[t]{7}{*}{ All Media } & $\begin{array}{l}\text { Cultural Resource } \\
\text { Review }\end{array}$ & $\begin{array}{l}10 \text { CFR } 1021, \\
36 \text { CFR } 63 \text {, } \\
36 \text { CFR } 800 \text {, } \\
43 \text { CFR } 7 \\
16 \text { USC } 461-470 \mathrm{aa} \text {, } \\
42 \text { USC } 1996 \text {, } \\
42 \text { USC } 4321\end{array}$ & $\begin{array}{l}\text { DOE, } \\
\text { State Historic } \\
\text { Preservation } \\
\text { Office }\end{array}$ & $\begin{array}{l}\text { Archaeological, } \\
\text { Any surface } \\
\text { disturbance, } \\
\text { Building mods, } \\
\text { Historic Register } \\
\text { eligibility }\end{array}$ & \\
\hline & $\begin{array}{l}\text { Ecological Compliance } \\
\text { Review }\end{array}$ & $\begin{array}{l}10 \text { CFR } 1021, \\
50 \text { CFR } 17, \\
50 \text { CFR } 402.6, \\
16 \text { USC } 703-712, \\
16 \text { USC } 1531, \\
\text { DOE Order } 5484.1 \text {, } \\
\text { WAC } 232-12\end{array}$ & $\begin{array}{l}\text { USFWS, } \\
\text { Ecology }\end{array}$ & $\begin{array}{l}\text { Construction, } \\
\text { Excavation, } \\
\text { habitat mods, } \\
\text { protection of } \\
\text { threatened or } \\
\text { endangered } \\
\text { species }\end{array}$ & 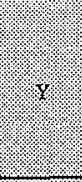 \\
\hline & $\begin{array}{l}\text { American Indian } \\
\text { Policies Review }\end{array}$ & $\begin{array}{l}42 \text { USC } 1966 \\
\text { DOE } 1230.2\end{array}$ & $\begin{array}{l}\text { DOE, } \\
\text { BIA }\end{array}$ & $\begin{array}{l}\text { Actions impacting } \\
\text { tribal interests, } \\
\text { energy, cultural, and } \\
\text { environmental }\end{array}$ & ג \\
\hline & $\begin{array}{l}\text { Floodplain/Wetland } \\
\text { Assessment }\end{array}$ & 10 CFR 1022 & DOE & $\begin{array}{l}\text { Any surface } \\
\text { disturbance }\end{array}$ & 1 \\
\hline & $\begin{array}{l}\text { Site Location } \\
\text { Review }\end{array}$ & $\begin{array}{l}\text { Hanford BMP } \\
\text { HNF-PRO-551 }\end{array}$ & FDH Landlord & Before final design & \\
\hline & Excavation Permit & 36 CFR 800 & DOE & $\begin{array}{l}\text { Before any } \\
\text { excavation }\end{array}$ & $y$ \\
\hline & $\begin{array}{l}\text { Preoperational Moni- } \\
\text { toring of Facility or } \\
\text { Site/Operations }\end{array}$ & DOE Order 5400.1 & DOE & Before operation & \\
\hline
\end{tabular}


HNF-2401, Rev. 0

\begin{tabular}{|c|c|c|c|c|c|}
\hline $\begin{array}{l}\text { ENVIRONMENT- } \\
\text { MEDIA }\end{array}$ & $\begin{array}{l}\text { PERMIT, APPROVAL, } \\
\text { or REQUIREMENT }\end{array}$ & REGULATION(\$) * & $\begin{array}{l}\text { REGULATORY } \\
\text { AGENCY }\end{array}$ & RESTRICTION & $\begin{array}{l}\text { APPLY? } \\
(Y \text { or } N)\end{array}$ \\
\hline \multirow[t]{3}{*}{ All Media (cont) } & $\begin{array}{l}\text { General Radiation Pro- } \\
\text { gram/Protection } \\
\text { Standards }\end{array}$ & $\begin{array}{l}\text { DOE Order } 5400.1 \text {, } \\
\text { DOE Order } 5400.5\end{array}$ & DOE & $\begin{array}{l}\text { Prior to any } \\
\text { Construction }\end{array}$ & 4 \\
\hline & $\begin{array}{l}\text { Radioactive Waste } \\
\text { Management }\end{array}$ & DOE Order $5820.2 \mathrm{~A}$ & DOE & Waste Management & 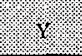 \\
\hline & $\begin{array}{l}\text { External Sample/ } \\
\text { Analysis }\end{array}$ & EPA-SW-846 & EPA & $\begin{array}{l}\text { Certified results for } \\
\text { compliance }\end{array}$ & Serkst \\
\hline All Air Emissions & $\begin{array}{l}\text { Air Operating } \\
\text { Permit }\end{array}$ & WAC $173-401$ & $\begin{array}{l}\text { Ecology, } \\
\text { WDOH, } \\
\text { EPA }\end{array}$ & $\begin{array}{l}\text { Construction, } \\
\text { Operation }\end{array}$ & y \\
\hline \multirow[t]{5}{*}{$\frac{\text { Nonrad. Air }}{\text { Emissions }}$} & $\begin{array}{l}\text { Source Review/NOC; } \\
\text { Source Registration }\end{array}$ & $\begin{array}{l}\text { WAC 173-400-110; } \\
\text { WAC 173-400-101; }\end{array}$ & Ecology & Construction & \\
\hline & $\begin{array}{l}\text { Substantial Alteration } \\
\text { of Emission Control } \\
\text { Technology }\end{array}$ & WAC $173-400-114$ & WDOH & Construction & $\mathrm{SOCH}=\mathrm{x}$ \\
\hline & $\begin{array}{l}\text { Prevention of } \\
\text { Significant } \\
\text { Deterioration }\end{array}$ & WAC 173-400-141 & Ecology & Construction & $\mathrm{sentx}$ \\
\hline & $\begin{array}{l}\text { Toxic Air } \\
\text { Pollutants, Source } \\
\text { Review }\end{array}$ & $\begin{array}{l}\text { WAC } 173-460-030 \\
\text { WAC } 173-060-040\end{array}$ & Ecology & Construction & setenoxt \\
\hline & $\begin{array}{l}\text { Dangerous/ } \\
\text { Hazardous waste, } \\
\text { RCRA air emissions }\end{array}$ & $\begin{array}{l}\text { WAC 173-303 } \\
-120(4)(e),-400(3), \\
-690 \text {, and }-691 \text {, } \\
40 \text { CFR } 264 / 265 \\
\text { Subpart CC } \\
\end{array}$ & $\begin{array}{l}\text { Ecology } \\
\text { and } \\
\text { EPA }\end{array}$ & Operations & toxt \\
\hline \multirow[t]{2}{*}{$\begin{array}{l}\text { Radioactive } \\
\text { Air } \\
\text { Emissions }\end{array}$} & $\begin{array}{l}\text { Source Review/NOC } \\
\text { Radiation Protection - } \\
\text { Air Emissions }\end{array}$ & WAC 246-247-060 & WDOH & $\begin{array}{l}\text { Construction, } \\
\text { Operation }\end{array}$ & $\mathrm{Su} x \mathrm{t} x \mathrm{xt}$ \\
\hline & NESHAPS & $\begin{array}{l}40 \text { CFR } 61 \\
\text { Subpart } H\end{array}$ & EPA & Construction & sestext \\
\hline \multirow{5}{*}{$\begin{array}{l}\text { Special } \\
\text { Substances }\end{array}$} & Toxic Substances & 40 CFR 720 & EPA & \multirow{2}{*}{$\begin{array}{l}\text { Design, Special } \\
\text { training, special } \\
\text { controls } \\
\text { Notifications }\end{array}$} & \multirow[t]{2}{*}{$\mathrm{Se}-1 \mathrm{HXt}$} \\
\hline & PCBs & $\begin{array}{l}40 \text { CFR } 761 \text {, } \\
\text { WAC } 173-303\end{array}$ & EPA, Ecology & & \\
\hline & Pesticides, herbicides & WAC- 228 to 232 & $\begin{array}{l}\text { State Department } \\
\text { of Agriculture }\end{array}$ & Registration and use & Scetext \\
\hline & Waste oils & $\begin{array}{l}\text { Wac 173-303-040, } \\
-360,-515 \\
40 \text { CFR } 279\end{array}$ & Ecology, EPA & $\begin{array}{l}\text { Use and } \\
\text { management of } \\
\text { used oils }\end{array}$ & Sedrox \\
\hline & $\begin{array}{l}\text { Spills and releases of } \\
\text { hazardous substances }\end{array}$ & $\begin{array}{l}40 \text { CFR } 302,-355 \text {, } \\
-372 \\
\text { WAC } 173-340\end{array}$ & Ecology, EPA & $\begin{array}{l}\text { Upon release, before } \\
\text { offsite transport }\end{array}$ & Sertext \\
\hline
\end{tabular}




\begin{tabular}{|c|c|c|c|c|c|}
\hline $\begin{array}{l}\text { ENVIRONMENT- } \\
\text { MEDIA }\end{array}$ & $\begin{array}{l}\text { PERMTT, APPROVAL, } \\
\text { or REQUIREMENT }\end{array}$ & REGULATION(S) * & $\begin{array}{l}\text { REGULAATORY } \\
\text { AGENCY }\end{array}$ & RESTRICTION & $\begin{array}{l}\text { APPLY? } \\
(\mathrm{Y} \text { or } \mathrm{N})\end{array}$ \\
\hline Asbestos & Notice of Intent & $\begin{array}{l}\text { BCCAA Reg. 1, } \\
\text { Article } 8 \\
40 \text { CFR } 61 \\
\text { Subpart M } \\
\end{array}$ & $\mathrm{BCCAA}$ & $\begin{array}{l}\text { Special training, } \\
\text { Notification before } \\
\text { working with } \\
\text { Asbestos } \\
\end{array}$ & \\
\hline $\begin{array}{l}\frac{\text { Outdoor or }}{\text { Unconfined }} \\
\text { Burning }\end{array}$ & Burn Permit & $\begin{array}{l}\text { WAC 173-425; } \\
\text { BCCAA Reg. 1, } \\
\text { Article } 5\end{array}$ & $\begin{array}{l}\text { Hanford Fire De- } \\
\text { partment \& BCC- } \\
\text { AA }\end{array}$ & Open Burning & \\
\hline $\begin{array}{l}\text { CFCs, Ozone } \\
\text { Depleting Sub- } \\
\text { stances }\end{array}$ & $\begin{array}{l}\text { Release Prevention; } \\
\text { Recovery/Recycle; } \\
\text { Certification Labeling } \\
\end{array}$ & 40 CFR 82 & Ecology & $\begin{array}{l}\text { Reporting, Training, } \\
\text { Operation }\end{array}$ & \\
\hline \multirow[t]{3}{*}{$\begin{array}{l}\frac{\text { Soil Column }}{\text { Waste Water }} \\
\text { Disposal }\end{array}$} & $\begin{array}{l}\text { State Waste Discharge } \\
\text { Permit Water Quality } \\
\text { Stds }\end{array}$ & $\begin{array}{l}\text { WAC } 173-200 \\
\text { WAC } 173-216 / 218\end{array}$ & $\begin{array}{l}\text { Ecology, } \\
\text { WDOH }\end{array}$ & $\begin{array}{l}\text { Monitoring plan, } \\
\text { Operation }\end{array}$ & 4 \\
\hline & $\begin{array}{l}\text { Approval of Engr. } \\
\text { Report, Plans \& Specs., } \\
\text { and O\&M Manual }\end{array}$ & WAC $173-240$ & Ecology & Construction & \\
\hline & $\begin{array}{l}\text { UIC Permit/ } \\
\text { Registration } \\
\end{array}$ & WAC 173-218 & Ecology & Operation & 1 \\
\hline \multirow[t]{5}{*}{$\begin{array}{l}\text { Domestic Waste } \\
\text { Water Disposal }\end{array}$} & $\begin{array}{l}\text { Septic Systems } \\
<14,500 \text { gpd cap. } \\
\text { Design Approval }\end{array}$ & WAC 246-272 & WDOH & Construction & \\
\hline & $\begin{array}{l}\text { Septic Systems } \\
>14,500 \text { gpd cap. } \\
\text { Design Approval }\end{array}$ & $\begin{array}{l}\text { WAC 173-216; } \\
\text { WAC } 173-240\end{array}$ & Ecology & Construction & \\
\hline & Pretreatment Permit & $\begin{array}{l}40 \text { CFR } 403 ; \\
\text { City Ordinance }\end{array}$ & city of Richland & $\begin{array}{l}\text { Discharge to city } \\
\text { sewage facility }\end{array}$ & \\
\hline & Operator Certification & WAC $173-230$ & Ecology & Operation & N \\
\hline & Discharge Standards & WAC 173-221 & Ecology & Discharge & Ne \\
\hline \multirow{7}{*}{$\frac{\text { Surface Waste }}{\text { Water Disposal }}$} & NPDES Permit & $40 \mathrm{CFR} 122$ & EPA & Operation & N \\
\hline & $\begin{array}{l}\text { Certification of NPDES } \\
\text { Permit }\end{array}$ & $40 \mathrm{CFR} 121$ & Ecology & Operation & 11 \\
\hline & $\begin{array}{l}\text { Storm Water Discharge } \\
\text { Under General Permit }\end{array}$ & 57 FR No. 175 & EPA & River Construction & $\mathrm{x}$ \\
\hline & $\begin{array}{l}\text { U.S. Dept of Axmy } \\
\text { Permit }\end{array}$ & $33 \mathrm{CFR} 325$ & USACE & River Construction & \\
\hline & $\begin{array}{l}\text { Wild \& Scenic River } \\
\text { Section } 10 \text { Permit }\end{array}$ & $\begin{array}{l}33 \text { CFR 320; } \\
33 \text { CFR } 322\end{array}$ & USACE & River Construction & \\
\hline & $\begin{array}{l}\text { Nationwide Waterway } \\
\text { Permits }\end{array}$ & 33 CFR 330 & USACE & River Construction & U. \\
\hline & $\begin{array}{l}\text { Hydraulic Projects } \\
\text { Permit }\end{array}$ & WAC 220-110 & $\begin{array}{l}\text { State Dept. of } \\
\text { Fisheries }\end{array}$ & River Construction & \\
\hline
\end{tabular}


HNF-2401, Rev. 0

\begin{tabular}{|c|c|c|c|c|c|}
\hline $\begin{array}{l}\text { ENVIRONMENT- } \\
\text { MEDIA }\end{array}$ & $\begin{array}{l}\text { PERMIT, APPROVAI, } \\
\text { or REQUIREMENT }\end{array}$ & REGULATION(S) * & $\begin{array}{c}\text { REGULATORY } \\
\text { AGENCY }\end{array}$ & RESTRICTION & $\begin{array}{l}\text { APPLY? } \\
(Y \text { or } N)\end{array}$ \\
\hline \multirow{5}{*}{$\frac{\text { Surface Waste }}{\text { Water Disposal }}$} & $\begin{array}{l}\text { Shoreline Development } \\
\text { Permit }\end{array}$ & WAC $173-14$ to -20 & Benton County & $\begin{array}{l}\text { River/Island } \\
\text { Construction }\end{array}$ & \\
\hline & Aquatic Lands Lease & WAC $332-30$ & $\begin{array}{l}\text { State Dept of } \\
\text { Natural } \\
\text { Resources } \\
\end{array}$ & Construction & \\
\hline & $\begin{array}{l}\text { Hanford Reach Study } \\
\text { Act Notification }\end{array}$ & PL 100-605 & U.S. Park Service & $\begin{array}{l}\text { Construction within } \\
1 / 4 \mathrm{mi} \text {. of River }\end{array}$ & 38 \\
\hline & $\begin{array}{l}\text { Water Quality Modi- } \\
\text { fication Permit }\end{array}$ & WAC 173-201 & Ecology & River Construction & \\
\hline & Categorical Standards & 40 CFR 405 to 471 & EPA & $\begin{array}{l}\text { Monitoring Plan, } \\
\text { Operation }\end{array}$ & $8 \mathrm{xp}$ \\
\hline \multirow[t]{3}{*}{$\begin{array}{l}\text { Drinking Water } \\
\text { Supply }\end{array}$} & $\begin{array}{l}\text { Approval of Engr. } \\
\text { Report, Plans and } \\
\text { Specs. }\end{array}$ & WAC $246-290$ & WDOH & Construction & $\mathrm{S} 8 \mathrm{~T}$ \\
\hline & System ID. Number & WAC 246-290 & WDOH & Operation & N \\
\hline & Operator Certification & WAC 246-292 & WDOH & Operation & 18 \\
\hline \multirow[t]{2}{*}{$\begin{array}{l}\text { High-Level } \\
\text { Waste }\end{array}$} & $\begin{array}{l}\text { Reprocessing of Spent } \\
\text { Nuclear Fuel }\end{array}$ & $\begin{array}{l}\text { Atomic Energy Act } \\
\text { DOE Order 5820.2A } \\
10 \text { CFR } 962 \\
40 \text { CFR 191 }\end{array}$ & \multirow[t]{2}{*}{$\begin{array}{l}\mathrm{DOE} / \mathrm{RL} \\
\mathrm{EPA} \\
\text { NRC }\end{array}$} & $\begin{array}{l}\text { Operation, } \\
\text { Treatment, } \\
\text { Packaging, } \\
\text { Store/Ship }\end{array}$ & \multirow[t]{2}{*}{ 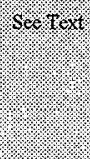 } \\
\hline & Design Criteria & DOE Order $6430.1 \mathrm{~A}$ & & Transfers & \\
\hline Solid Waste & $\begin{array}{l}\text { Solid Waste Facility } \\
\text { Permit, } \\
\text { Waste Minimization }\end{array}$ & $\begin{array}{l}\text { WAC 173-304, } \\
40 \text { CFR } 262 \text { to } 265 \text {, } \\
\text { DOE } 5400.1\end{array}$ & $\begin{array}{l}\text { Ecology, } \\
\text { County Health } \\
\text { Dept }\end{array}$ & Construction & secosed \\
\hline \multirow[t]{4}{*}{ Dangerous Waste } & $\begin{array}{l}\text { Dangerous Waste } \\
\text { Permit (RCRA Part A } \\
\text { and B) }\end{array}$ & $\begin{array}{l}\text { WAC 173-303-800 } \\
-860 ; 40 \text { CFR 264, } \\
40 \text { CFR 265, and } \\
40 \text { CFR 270 }\end{array}$ & Ecology & $\begin{array}{l}\text { Construction of } \\
\text { New Facility, or } \\
\text { Expansion of Exist } \\
\text { Facility }\end{array}$ & \\
\hline & Notice of Intent & WAC 173-303-281 & Ecology \& Public & $\begin{array}{l}\text { Public Reading } \\
\text { Room \& } \\
\text { Newspaper }\end{array}$ & $5 \%$ \\
\hline & $\begin{array}{l}\text { Construction or } \\
\text { expansion of surface } \\
\text { impoundments, waste } \\
\text { piles, or landfill units }\end{array}$ & WAC 173-303-335 & Ecology & $\begin{array}{l}\text { Construction quality } \\
\text { assurance plans, } \\
\text { program, and } \\
\text { certification }\end{array}$ & $x$ \\
\hline & $\begin{array}{l}\text { Non-Standard } \\
\text { Methods/RD\&D }\end{array}$ & $\begin{array}{l}\text { WAC } 173-303-500 \\
\text { to }-607,-809 \text { and } \\
-830\end{array}$ & Ecology & $\begin{array}{l}\text { RD\&D Permit, } \\
\text { Waivers }\end{array}$ & 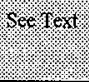 \\
\hline USTS & Tank Permit & WAC 173.360 & Ecology & Operation & See rex \\
\hline
\end{tabular}

* These are the 'major' requirements; additional secondary requirements will be identified in the evaluations. 
NEPA

\section{National Environmental Policy Act (NEPA) Documentation - Title 10, CFR 1021}

The NEPA requires federal agencies to examine ALL activities for effects on the environment. This is done by preparing an Environmental Impact statement (EIS) or an Environmental Assessment (EA). A NEPA compliance review is required for all proposed actions at Hanford to determine the appropriate level of environmental documentation. A categorical exclusion (CX) is issued by RL if the proposed action clearly has no significant impact on the quality of the human environment. However, all actions qualifying for a CX must still be documented.

A NEPA Request Checklist is on the Hanford IntraNet (Environmental Services home page) which is completed and forwarded to WMH NEPA Services Team to initiate the review process. NEPA documentation must be completed before starting Title II Design, or long lead procurements.

Note: Cultural resource surveys and ecological survey must also be completed before NEPA documentation is submitted to RL. Sample NEPA documentation may be read on the Hanford Intranet, Environmental Services home page. Projects with multiple potential locations must complete a Site Location Review (see following); this same process is also considered in the EA/EIS.

\section{Price-Anderson Amendments Review - 10 CFR 835}

If a project or corrective action is being done in response to a deficiency or non-conformance under the Price-Anderson Amendments (PAA), then the closure authority, (defined in the PAA determination, and which is listed in the site Deficiency Tracking System database [DTS]), and the PHMC Legal Office must also review the project scope and NEPA determination, plus the permits which will redefine closure of the deficiency and provide a basis for restart of the facility/process. A PAA guidance document is available on the Hanford IntraNet; see HNF-1950. See also HNF-MD-006 and HNF-MP-599.

EVALUATION: It is assumed that the WFD project and its supporting tasks are suitably covered by the existing TWRS Environmental lmpact Statement (DOE/EIS-0189) and the TWRS Safe Interim Storage EIS (DOE/EIS-0212) and the associated Record of Decision(s). The WFD project will also incorporate numerous repeated, low impact tasks covered under Categorical Exclusion. During the permit application development period, all details of the proposed processes will be evaluated. If it appears that a particular task/activity is not suitably covered in the existing NEPA documents an environmental assessment (EA) or a supplemental (EIS) assessment will be prepared. The decision to do this will be made (ad-hoc) by the RL NEPA Compliance Officer. There are no current PAA issues identified for WFD.

Contact R. D. Potter (373-9315 for WFD general project environmental support. For additional assistance, contact Ms G. D. Cummins (372-2484) or K. R. Welsch (376-4373) for NEPA interpretations. Contact L. P. Diediker (373-1716) for Price-Anderson environmental issues. Contact Barbara Williamson (376-6492) at FDH Legal for PAA closure issues. 
HNF-2401, Rev. 0

SEPA

\section{State of Washington Environmental Policy Act Documentation - WAC 197-11}

SEPA is the State equivalent of NEPA, requiring evaluation of the project's environmental impacts before it can be approved. A SEPA checklist is completed when required by Ecology; (typically only if some state permit, other than an air permit is needed). An EIS or EA developed under NEPA may substitute (at the option of Ecology) for the SEPA checklist. The DOE/RL NEPA Compliance Officer will forward copies of the NEPA documentation and/or SEPA Checklist to the State. Ecology will determine if a State EIS is required or will issue a determination of non-significance.

EVALUATION: Since Ecology co-prepared the TWRS EIS, we assume that they will accept the existing NEPA documentation, as sufficient to meet the SEPA requirements. It is recommended that the project provide a briefing to the State (Ecology), stating that DOE/RL believes that existing documentation covers the proposed WFD activities. A notification letter to Ecology, identifying adoption of the NEPA documentation for WFD in lieu of a SEPA checklist is suggested.

Contact R. D. Potter (373-9315 for WFD general project environmental support. For additional assistance, contact Ms G. D. Cummins (372-2484) or K. R. Welsch (376-4373) for NEPA interpretations, and K. R. Welsch (376-4373) for interpretation of SEPA requirements.

\section{NEPA 216 Process/Environmental Critique - 10 CFR 1021.216}

For those procurement actions with potential environmental liabilities, which are not specifically included in the NEPA documentation, the environmental impacts must be evaluated prior to placing service contracts with external suppliers. All bidder proposals must be evaluated for past compliance history, effectiveness of proposed mitigation, and the potential bidder responsibilities for environmental compliance. The NEPA compliance guidelines in 10 CFR 1021.216 must be followed and the results issued in an Environmental Critique. Evaluation results must also be approved by the DOE/RL NEPA Compliance Office prior to final contract. These evaluations become part of the formal procurement documentation and may be published as part of the public record.

EVALUATION: It is assumed that no NEPA 216 procurement of systems or services will be needed for WFD project.

\section{CERCLA}

Comprehensive Environmental Response, Compensation and Liability Act: Applicable or Relevant and Appropriate Requirements (ARARs)- 40 CFR 300.400

No Federal, State, or local permits are required for onsite response actions covered by CERCLA, Sectionis $104,106,120,121,121$, or 122 . The Hanford Site has been included on the National Priorities List, under CERCLA section 300 . This exception is allowed because onsite response actions must comply with the substantive parts of ARARs. On the Hanford Site, an activity is recognized as a CERCLA activity if the unit is identified as a CERCLA operable unit in the Tri-Party Agreement, or the activity is documented and performed in accordance with the CERCLA process. CERCLA remedial actions must comply with the 
substantive requirements of ARARs both during the remedial action and upon completion of the remedial action. The Hanford Federal Facility Agreement and Consent Order of 1989 recognizes that some CERCLA. releases may be covered by the Washington State Model Toxics Control Act (MTCA). These will be included as ARARs, where appropriate; see HNF-PRO-454 \& HNF-PRO-455.

Additionally, removal actions (commonly called interim actions or expedited response actions) must comply with ARARs depending upon the urgency and scope of the circumstances and the removal action. The substantive portions of ARARs are generally required unless the removal is an emergency situation that does not allow for a planning phase to identify ARARs.

\section{Model Toxics Control Act (MTCA), WAC 173-340}

Ecology will use the Model Toxics Control Act residual standards (analogous to CERCLA standards) to make decisions regarding the "contained-in policy" for miscellaneous media. If environmental media are contaminated with a listed waste, AND meet the definition of debris (WAC 173-303-040 \& 40 CFR 268.2), AND the solids exceed $60 \mathrm{~mm}$-- then alternative treatment standards of 40 CFR 268.45 may be applicable, instead. (See Special Substances section, following).

Most CERCLA actions are the responsibility of the Environmental Restoration Contractor; contact BHI Environmental Compliance for additional interpretive details.

EVALUATION: It is assumed that the WFD project will only involve RCRA wastes; no

CERCLA/MTCA requirements will be involved in Phase 1.

\section{ALL MEDIA}

\section{Cultural Resources Review - 36 CFR 800}

A cultural review shall be performed for any project involving demolition, modification, or deactivation of a potentially historic facility or structure. The cultural review must be made before initiating any external surface-disturbing activities onsite, or if any modifications are planned for any facility with the potential for inclusion on the National Register of Historic Places. The request to perform this review is macro GEF271.

\section{Ecological Compliance Review - 10 CFR 1021; 50 CFR 402.6; DOE Order 5484.1}

A site survey should be performed to identify: Any plant or animal species protected under the Endangered Species Act; candidates for such protection; species listed as threatened, endangered, candidate, sensitive, or monitored by the state of Washington; and species protected under the Migratory Bird Treaty Act. Also assessed is whether the planned activities have the potential to disturb any priority habitats and/or species identified in the survey. The request form to perform this review is macro GEF271. This review also fulfills the NEPA ecological/biological review requirement.

NOTE: This section also applies to: taking, possession, transportation, sale, purchase/barter, export, and import of special status plants and animals (both living and dead). It includes removal/remediation action, corrective action, decontamination/decommissioning (D\&D) activities, and project construction activity. 


\section{American Indian Tribal Government Agreements - DOE 1230.2}

American Indian Tribal Governments have a special and unique legal relationship with the US Federal Government and its agencies. These are defined in numerous treaties, statues, historical precedents, and the US Constitution. In addition, the state of Washington has agreements respecting current and future use of the lands surrounding the Hanford Site. All actions on the Hanford Site which may impact these agreements must be approved by the DOE-RL office for native American interests. The Cultural Resource Review will be the mechanism for identifying any such potential impacts.

EVALUATION: It is assumed that all actions included under the WFD project will occur inside or within 150 meters of the 200 East/200 West tank farm boundaries. The WFD areas have an existing cultural review (initially Aug. 16, 1994; updated annually). No further review should be needed.

It is recommended that each supporting project request a baseline ecological resources survey as soon as the specific site locations and proposed impact areas have been determined; see Site Location Survey section, following.

It is assumed that no new actions within the 200 Area boundary will impact existing Native American Tribal agreements; this should be verified by contacting the RL Tribal Interface Office.

Contact Ms. N. Cadoret (376-8107) for cultural review questions, or Dee Lloyd/RL (372-2299) for cultural/historic interpretations. If the Project later identifies potential impacts, contact K. V. Clarke (376-6332), DOE/RL liaison for Indian Affairs.

\section{Floodplain/Wetland Assessment - 10 CFR 1022}

A Floodplain/Wetland Assessment applies to all proposed floodplain/wetlands actions. A proposed action shall be designed to minimize potential harm to or within a floodplain. The assessment should be performed in conjunction with the NEPA process.

EVALUATION: Not applicable; the WFD project will not include any floodplain or wetlands activity.

\section{Site Location Review - HNF-PRO-551, Section 3.3.2.3}

Any new facility must receive a landlord site location review, coordinated by Dyncorp/Site and Land Use Planning organization. This review is a Hanford best management practice. It offers an opportunity during the early planning stages to identify unusual or uncertain compliance, safety or operations issues; it covers similar aspects as the alternatives review under NEPA (Environmental Impact Statement, or Environmental Assessment). 
EVALUATION: A siting evaluation should be made of the proposed routing for all underground piping, pits, pads, and support structures within WFD. A review for intrusion into radiation control areas, underground contamination areas and buried tanks should also be made to avoid any unanticipated exposures. Data from the site location review should be kept for reference use by the excavation permit authority.

Contact R. D. Potter (373-9315) for WFD general project environmental support. Contact E. F. Yancey (376-8134), to initiate the Site Location Review: Contact J. I. Gould (376-1157), for additional environmental issues identification.

\section{Excavation Permit - 36 CFR 800}

An excavation permit is required before initiating any potential surface-disturbing onsite activities. The request form to obtain this permit is located on the HLAN, under Site Forms, [A-7400-373, "Hanford Excavation Permit"]. The facility Environmental Compliance Officer (ECO) can review and approve excavation permits before excavation begins, to ensure that all environmental, cultural, and ecological resource review issues are met.

EVALUATION: Detailed information needed for the excavation permits under WFD will be the responsibility of each individual supporting project. Data from the site location review should be examined during the approval of the excavation permits.

Contact the TWRS Environmental Compliance Officer P. C. Miller (373-6389), or C. J. Grando (373-1029) for excavation permit environmental issues and application approval. Contact D. A. Nawarynsky (376-6173) for assistance with sitewide excavation permit preparation.

\section{Pre-operational Monitoring of Facilities, Sites, and Operations - DOE Order 5400.1}

A pre-operational environmental study shall be conducted before startup of a site, facility, or process that has the potential for significant adverse environmental impact. This study should begin not less than one year (preferably two years) before startup, so seasonal changes can be evaluated. This study precedes the conceptual design report and can include data acquired in the site selection process, excavation permit process, and NEPA/SEPA process. For more information see the environmental compliance procedures, HNF-PRO-453, HNF-PRO-456 \& HNF-PRO-457.

EVALUATION: It is assumed that each individual supporting project will request a pre-operational survey of the proposed usage location, as soon as the site evaluation review (see above) is complete.

Contact R. D. Potter (373-9315) for WFD general environmental support. Contact A. R. Johnson (372-3056) for operational monitoring. 


\section{General Public/Environmental Protection - DOE Order 5400.1 Radiation Protection Standards - DOE Order 5400.5}

DOE Order 5400.1 requires all Hanford facilities and projects to incorporate a overall protection program for environment, the public and workers.

DOE Order 5400.5 establishes standards and requirements that must be followed to protect members of the public and environment against undue risk from radiation. DOE Order 5400.1 requires that all DOE Sites prepare an environmental monitoring plan. DOE/RL 91-50, Environmental Monitoring Plan, includes DOE/EH-0173T, Environmental Regulatory Guide for Radiological Effluent Monitoring and Environmental Surveillance, which provides specific guidance regarding environmental monitoring activities.

EVALUATION: The WFD will need to incorporate the current Radiation Protection Standards as part of its overall compliance strategy. The WFD project must ensure that individual supporting projects integrate their impacts such that the entire WFD impact totals remain well within acceptance guidelines.

The Project should supply all required data to the technical authority for the site monitoring plan document (DOE/RL 91-50), and individual Facility Effluent Monitoring Plan (FEMP) revisions, well before required schedule(s).

Contact R. D. Potter (373-9315) for WFD general environmental support. Contact C. J. Grando (373-1029) for data identification needs. Contact L. P. Diediker (373-1716) for assistance in applying the Radiation Protection Standards.

\section{ALL AIR EMISSIONS}

\section{Air Operating Permit - WAC 173-401}

WAC 173-401 establishes a comprehensive Washington State AOP program meeting the requirements of Title $\mathrm{V}$ of the Federal Clean Air Act. A single sitewide permit is required for the Hanford facilities. This permit covers both radioactive and nonradioactive airborne emissions from all emission units that meet significance criteria defined by the Act.

The airborne emissions include criteria pollutants and hazardous air pollutants (including radionuclides). In this regulation, Ecology also has established thresholds for regulated pollutants below which emissions are considered insignificant (Insignificant Emission Units/LEUs) for the purposes of the AOP program. IEU items/activities must comply with general standards, but are exempt from the administrative requirements of the permit.

The AOP identifies emission limits and conditions of operation for sources on the Hanford Site. If a new NOC is required (refer to following section), and an emission unit becomes operational after the AOP is issued by the state, an AOP revision may be required before commencing operation. This application for modification is prepared in accordance with WAC 173-401-725. The NOC and AOP modification can be sought concurrently. Any NOC application and associated documentation must be retained by the facility. 
EVALUATION: The Hanford facility Air Operating Permit is scheduled to be completed and submitted for State approval by June 1998. All known, existing registered air sources will have been collected into this permit at that time. It is assumed that the WFD project, plus all supporting projects will have all effective air emissions point sources incorporated into the final AOP.

At the time that each supporting project reaches final design stage, a compliance review of the air emission source(s) should be made, to determine whether additional data needs to be provided for the next AOP revision. If the supporting project will incorporate a totally new release point (stack) or significantly modify existing tank farm ventilation systems, review/approval by the State (both Ecology \& Health) should be requested.

Contact R. D. Potter (373-9315) for WFD general environmental support.

Contact B. G. Curn (372-0840) for Air Operating Permit questions.

Contact C. J. Grando (373-1029) for project data identification needs.

\section{NONRADIOACTIVE AIR EMISSIONS}

\section{New Source Review Applicability - WAC 173-400-110}

Source Registration - WAC 173-400-101

Any new activity, project, process, or equipment that will involve potential emissions of contamination to the air is subject to a preconstruction review and approval by the Washington State. Also, if the activity involves a physical or operational change at an existing source of air emissions, and the change will result in ANY increase in the rate of contaminant emissions to the ambient air from the existing source, this is considered a modification.

To determine whether a change constitutes such a modification, emissions which will result after the change are compared to a baseline which is normally the annual rate of emissions observed from the facility, structure, or process(es) during the previous 2 years of operations. Other options for definition of the baseline exist and may be negotiated with Ecology.

The increase may be related to such factors as increased flow rate or concentration of effluent, upstream heating or mixing of source material, or increased exposure to outside air. When determining whether increased emissions would occur, additional abatement by any planned emissions control equipment may not be factored in. However, use of best available control technology is often required.

The NOC must include a description of the new construction or modification activities with details concerning any effect the planned construction activity (or the new/changed operations) would have regarding containment or release of air contaminant emissions. The NOC must also include estimates of actual and potential emissions and an assessment of RACT, BACT and LAER. For activities having lesser impact potential, approval may be gained in a streamlined manner during a regularly scheduled monthly interface meeting. Once approved, the project must begin (construction/ installation) within 18 months.

NOTE: The need for a NOC also triggers the need for generating and maintaining specific records by the facility; see 40 CFR 61.95 and HFN-PRO-450. 


\section{Replacement or Substantial Alteration of Emission Control Technology - WAC 173-400-114}

A NOC application must be filed with Ecology when proposing to replace or substantially alter the emission control technology at an existing stationary source. Routine maintenance, repair, or similar parts replacement is NOT considered replacement or substantial alteration of control technology. Ecology may require the owner or operator to employ reasonably available control technology (RACT) for the affected emission unit, may prescribe reasonable operation and maintenance conditions for the control equipment, or may prescribe other requirements as authorized by Chapter $70.94 \mathrm{RCW}$. Approval to replace or substantially alter emission control technology becomes invalid if construction is not commenced within 18 months after receipt of approval, if construction is discontinued for a period of 18 months or more, or if construction is not completed within a reasonable time.

EVALUATION: It is assumed that the existing DST ventilation systems at the involved tank farms (AN, AP, AW, AY, AZ and SY) where applicable, will be the major air emission point sources for both radioactive and non-radioactive contaminant emissions. Filtration data and associated removal effectiveness can be derived from existing monitor data from the individual stack sampler systems, based on existing FEMPs.

Supportive data from these and other ancillary sources will be combined into the overall Hanford Air Operating Permit.

It is assumed that consolidated notices of construction (NOC) will be developed for each of the supporting projects, and data supplied to the State (Dept of Ecology and Health) for concurrence. The time to evaluate the data needed and to combine into the desired format for submittal has typically been about 5 months for past TWRS projects.

If a combined strategy for developing all the NOCs needed by the WFD is used, time per individual project NOC should be decreased significantly.

Contact K. A. Peterson (372-2364) for interpretation of hazardous air emissions issues. Contact C. J. Grando (373-1029) for identification of supporting data, and J. J. Luke (376-8629) for assignment of permitting staff to prepare the NOC application.

\section{Prevention of Significant Deterioration (PSD) - WAC 173-400-141}

Any increased emission of criteria pollutants from a new or modified source may trigger a significant modification as defined by 40 CFR 52.21. Potential annual amounts of expected increases must be considered. Preconstruction approval may be required by Ecology; see HNF-PRO-450. The criteria pollutants include:

\begin{tabular}{|c|c|}
\hline $\begin{array}{l}\text { - Carbon monoxide } \\
\text { - Nitrogen oxides } \\
\text { - } \quad \text { Pulfur dioxides } \\
\text { - (volatile) organic compounds* } \\
\text { * As defined in WAC } 173-400-030\end{array}$ & $\begin{array}{l}\text { Lead } \\
\text { - } \text { Sulfuorides } \\
\text { - Total reduced sulfur compounds }\left(\& \mathrm{H}_{2} \mathrm{~S}\right) \\
\text { - Municipal waste combustor - acidic gases, } \\
\text { metals, or organics. }\end{array}$ \\
\hline
\end{tabular}


If a Notice Of Construction is required, the potential annual emissions of the criteria pollutants must be estimated and included. (See NOC Section, above.)

New Sources of Toxic Air Pollutants (TAPs Requirements) - WAC 173-460

New Source Review (under TAPs) - WAC 173-400-040

Activities which are considered modifications or new construction must be assessed for possible TAPs permitting. TAPs are identified in WAC 173-460-150 and -160 . The TAPs evaluation will identify all major contributions and associated threshold action limits, along with required controls. Some key requirements are:

- Source quantity of each TAP other than nonprocess fugitive emissions,

- Source impact category (listed in WAC 173-460, or WAC 173-400),

- Source exempt components,

- "New source" of TAPs, or facility/source modification,

- Identify Best Available Control Technology for Toxics (T-BACT) and/or TAPs.

EVALUATION: The criteria will need to be evaluated individually by each of the supporting projects, to determine both individual and collective compliances.

It is assumed that mixing, retrieval and transfer processes will be controlled to minimize generation of aerosols and thus releases of nonradioactive emissions. Current Tank Ventilation systems do not have special systems for control of TAPs releases. A detailed evaluation for generation of TAPs and criteria pollutants will be needed for each tank which will serve as feed for the Privatization program.

Supporting data to determine threshold values of TAPs generation may require new sampling of the tanks, or evaluation of existing data and estimating of those TAPS likely to be individually significant, along with collective category concentrations. These estimates should be made on a priority screening basis, with those tanks likely to be involved, done first.

Following the identification of potential TAPs generated, by the WFD, a second evaluation should be done to determine the necessary control technology. It may be possible that existing BARCT and T-BACT determinations will be sufficient for approvals by Ecology and Health.

Contact K. A. Peterson (372-2364) for emission issues interpretation. Contact C. J. Grando (373-1029) for data identification of criteria pollutants and TAPs. Contact J. J. Luke (376-8629) for preparation of permit applications.

\section{RADIOACTIVE AIR EMISSIONS}

\section{Radiation Protection - Air Emissions - WAC 246-247 \\ Source Review/Notice Of Construction - WAC 246-247-060}

The WDOH will make a case-by-case determination regarding the need to register any new or modified source of radioactive air emissions requiring an NOC. If an NOC is required (see WAC 246-247) the same data may usually be combined for both WDOH and Ecology. 
Any new activity, process, or equipment that will involve potential emissions of radionuclides to the air is subject to a preconstruction review and approval by the WDOH. If the activity involves a physical or operational change at an existing source of radionuclide air emissions, and the change will increase the rate of emissions of radionuclides to the ambient air or the release of a radionuclide not previously released from the existing source, review and approval by the WDOH is required. Emissions resulting after the changes are compared to a baseline that is normally the anmual rate of emissions observed from the facility, structure, or operation during the prior two years of operations. Other options for definition of the baseline exist and may be negotiated with WDOH; see HNF-PRO-450.

The increase may be related to such factors as increased flow rate or concentration of effluent, upstream heating or mixing of source material, or increased exposure to outside air. When determining whether increased emissions would occur, additional abatement by any planned emissions control equipment may not be factored in.

A NOC application must be filed to obtain prior WDOH approval prior to commencement of the new or modified activity. The NOC must include a description of the new construction or modification activities with details concerning any affect the planned construction activity, or the new or changed operations would have regarding containment or release of radionuclide air emissions. The NOC must also include estimates of actual and potential emissions and an assessment of BARCT or ALARACT as defined in the WAC 246-247. Any new major source of radioactive air emissions or major modification to a source must employ Best Available Radioactive Control Technology, per WAC 246-247-030, and the Hanford Site Radioactive Control Manual (HSRCM-1). This must also meet ALARA standards; see HNF-PRO-450. 
EVALUATION: To Be Determined. The WFD project, via its supporting projects, is assumed to generate small changes in the existing air emissions quantities. The extent to which this will require changes in the tank farm source registration, compliance to current Protection Standards, and use of existing (or upgraded) control technology is uncertain.

Individual source evaluations for each of the registered point sources of radioactive emissions should be made, and estimates of the individual and collective impacts by each supporting project, and modes of operation should be reviewed to determine necessity of changes in the required permits.

Because the WFD activities are divided into many supporting projects, many permits or other documents may need preparation, revision, and/or extending. Some projects (W-151, W-211, and W-320) have an approved air permit application, but not all aspects of the projects are covered by the existing permits. Further, projects W-314 and W-519 need regulator approval of the submitted air permit application(s) or need air permit application(s) prepared.

Project W-151 and W-030 approvals are in place; it may be necessary to revise the NOC using a different ventilation flow rate and data for the source term.

Project W-211 scope is to install a waste retrieval system in 10 DSTs (AP-102, AP-104, AN-103, AN-104, AN-105, AN-107, AW-101, AT-102, AZ-102, and SY-102) between now and CY 2006. Because of the extended schedules and unknown activities/designs for cach tank, NOCs will be submitted as information becomes available.

The Project W-211 NOC provided the general descriptions of a mixer pump for tank SY-102, and its installation and mixing/retrieval process. Future NOCs submitted under W-211 would reference this same material, and provide specific information as needed to complete the approval process for each tank or group of tanks. Currently, the W-211 NOC is being revised for the AP-102/104 tanks.

Project W-320 approvals for sluicing are in place. It was determined to submit additional NOCs for retrieving the remaining heel. The permitting strategy for retrieving the heel from tank $241-\mathrm{C}-106$ is discussed in detail in HNF-SD-HTI-EV-001, Revision 1.

Project W-314, air permitting application(s) have been prepared and submitted. Currently, a "short-form" application has been submitted for regulator review and approval.

We recommended project W-519 secure the air permits (for applicable activities and affected facilities) before construction. We assume that a NESHAPs and TAPs application(s) will be submitted. It is assumed that W-519 activities will not result in emissions exceeding significant levels for any criteria pollutants under the PSD program. Additionally, installation of BARCT may be required.

Project W-519 provides infrastructure (i.e., piping) for transferring liquids from the boundaries of the private vendors to the liquid effluent facilities (LERF/ETF/TEDF). This will require interfacing with the private vendors and the appropriate operator(s) of LERF/ETF/TEDF. Installing the infrastructure items may disturb contaminated soils; therefore, it is recommended that W-519 be included in the permitting strategy for treating liquid effiuents at the LERF/ETF/TEDF.

Contact R. D. Potter (373-9315) for WFD general environmental support.

Contact J. A. Bates (376-2088) for WDOH interfacing assistance.

Contact C. J. Grando (373-1029) for data needs identification.

Contact J. J. Luke (376-8629) for assignment of permitting assistance. 


\section{National Emission Standards for Hazardous Air Pollutants (NESHAPs) - 40 CFR 61, Subpart H}

Any new stationary source of radionuclide emissions is subject to a preconstruction review and approval by the EPA, Region 10. Also, any new physical or operational activity which will provide any increase in potential emissions of radionuclides is defined as a modification and may require approval. Additional operational records are required by NESHAPs designation; see 40 CFR 61.14(f).

NOTE: A facility may already have a completed facility effluent monitoring plan, which may only need revision if the existing stack/emission point is registered and continuously monitored for compliance. All emissions points which require continuous monitoring must also be included in a quality assurance program, meeting 10 CFR 61, Appendix B.

EVALUATION: It is assumed that the WFD project will generate both radioactive and non-radioactive air emissions. Most radioactive contaminants can be controlled through the use of HEPA filter technology on exhaust systems. Each supportive project should evaluate the radioactive emissions on all point sources, and determine whether existing filtration systems will be effective. Both individual and collective emission impacts should be evaluated.

Data from the individual estimates should be provided to the preparers/revisers of the NOCs, the Hanford Air Operating Permit, the Part B permit and the FEMPs.

Contact J. A. Bates (376-2088) for radioactive air issues.

Contact L. P. Diediker (373-1716) for monitoring/sampling questions.

Contact C. J. Grando (373-1029) for data needs identification.

Contact J. J. Luke (376-8629) for permit preparation assistance.

\section{SPECIALLY CONTROLLED SUBSTANCES}

\section{Polychlorinated Biphenyls (PCBs) - 40 CFR 761 \& WAC 173-303}

PCB use, handling, and disposal are regulated by Washington State (WAC 173-303) if concentration is greater than 2 ppm, and by Federal legislation ( 40 CFR 761 et seq) if concentration is greater than 50 ppm. PCB wastes are often part of a mixture, derived-from or debris wastes (e.g., electrical power transformer fluid), which also have separate and special requirements. Refer to HNF-PRO-451 for additional PCB guidance.

EVALUATION: To Be Determined. It is not known whether any PCBs will be associated with equipment to be removed from the WFD project tank farms or ancillary systems. Any such items must be identified during final detailed design and provisions made to properly package and disposition them, by the Project.

A requirement will be included in the purchase specifications for any new equipment/systems, to prohibit the use of PCB-incorporating components, except in unusual circumstances. Such use should have the concurrence of the Program manager, the manager of Waster Generator Services, and the WFD Project Environmental Compliance Officer.

Contact R. D. Potter (373-9315) for WFD general environmental support.

Contact T. A. Quayle (376-5223) for questions on PCB designation and controls. Contact C. J. Grando (373-1029) for final design approvals. 


\section{Toxic Substance Control Act (TSCA) - 40 CFR 720}

TSCA requires all commercial chemicals be maintained on a TSCA inventory. Users must input data for the Hanford Site Inventory, when materials or new chemical substances are purchased or imported. Some research \& development activities are exempted from TSCA controls for "de minimus" quantities. TSCA guidelines give preference to use and recycling of all controlled materials. All chemical users must maintain the Material Safety Data Sheet in a convenient location near point of usage.

\section{Pesticides, Rodenticides and Herbicides - WAC 16-228/232 incl}

Miscellaneous poisons are controlled by the Federal Insecticide, Fungicide and Rodenticide Act (FIFRA). The Washington State Dept of Agriculture is authorized to implement these regulations. Users must comply with the WAC 16 requirements, for training, usage, handling, storage, disposal and record-keeping of items under FIFRA. See HNF-PRO-451 for additional guidance on FIFRA Controls.

EVALUATION: To Be Determined. It is assumed that any TSCA or FIFRA controlled materials will be small quantity volumes, at worst case. A detailed evaluation should be made during the supporting project final design to determine whether any such materials will be used. A waste-minimization/Pollution Prevention study by the Project is recommended, if simple screening shows the possibility for such.

Contact R. D. Potter for WFD general environmental support.

Contact W. E. Toebe (372-2359) for questions regarding designation and controls for chemicals, pesticides, herbicides and other toxic substances.

Contact Ms. D. S. Merry (376-9773) for waste minimization assistance.

\section{Waste Oils - WAC 173-303-040, -360, -515}

Waste oil is oil that has been used, and contains contaminants which are controlled under RCRA or other authority. Waste oils are not controlled as hazardous substances, unless they also contain other components which must be controlled as hazardous substances under Federal or State requirements. Controls for the Hanford Site are based only on the contaminant requirements that might be those of mixtures. Petroleum products being stored for eventual use are not considered waste. Special considerations allow waste oils with contaminants to be used for energy recovery, per WAC-173-303-515. Waste oils stored in small/portable containers may be exempted from some storage requirements; those stored in fixed tanks may need to meet design requirements in WAC 173-303-360, or DOE 6430.1A.

Evaluation: Not expected to affect WFD activities.

\section{Spills and Releases of Hazardous Substances - 40 CFR 302, -355, -372 and WAC 173-340}

Specially controlled substances may be subject to release. They may be released as vapor or in liquids as either dissolved or suspended materials. They might appear as solids within a solid or semi-solid waste matrix. Special documentation and emissions/release estimates may be required as part of the description for normal and upset operating conditions. Special reporting protocols must be followed if a release of greater than the reportable quantity occurs. 
Evaluation: Applicable. Spills and releases will be reported in accordance with existing sitewide procedures.

Contact J. R. Culmer (373-4392) for unplanned releases.

Contact J.O. Skolnud (376-6180) for toxic release inventory

\section{ASBESTOS}

\section{Asbestos - BCCAA General Regulation 1, Article 8; 40 CFR 61, Subpart M}

Asbestos is a controlled carcinogen. All work must be done by trained and certified personnel. Any proposed reconstruction, repair, or demolition involving asbestos must be reviewed by FDH Environmental Protection for possible preproject notification to the Benton County Clean Air Authority (BCCAA). All notifications will be handled by the central FDH Environmental Protection for the entire Hanford Site; see Notice of Intent section, following. Refer to HNF-PRO-450, for details.

EVALUATION: To Be determined. No asbestos components are planned for inclusion in new systems or equipment. There is a potential for some gasketing and piping materials to still have asbestos, which will be removed as part of the installation for new equipment. These will be controlled, packaged and dispositioned according to existing approved procedures.

Contact T. A. Quayle (376-5223) for asbestos requirements.

\section{OUTDOOR OR UNCONFINED BURNING}

\section{Burn Permit - WAC 173-425; BCCAA, Regulation 1, Article 5}

Any use of unconfined burning requires a permit from the local BCCAA obtained through the Hanford Fire Department. Special burn permits are required for demolition or fire training.

Evaluation: Not Applicable. It is assumed the WFD Project will not involve unconfined outdoor burning.

\section{OZONE DEPLETING SUBSTANCES}

\section{Ozone Depleting Substances/Chloroflurocarbons - 40 CFR 82}

Any person who produces, transforms, destroys, imports or exports a controlled (ozone depleting) substance (e.g., chloroflurocarbons) must perform the required reporting, training, and operations specified. See HNF-PRO-450 for details. 
EVALUATION: To Be Determined. It is assumed that the WFD Project will not involve use of significant amounts of ozone-depleting substances. A compliance review is recommended during final design, concurrent with a waste-minimization/Pollution prevention study to confirm this.

Contact R. D. Potter for WFD general environmental project support.

Contact Ms. D. S. Merry (376-9773) for assistance with waste minimization issues.

\section{SOI-COLUMN WASTE WATER DISPOSAL}

\section{State Waste Discharge Permit (SWDP) - WAC 173-216}

The SWDP is required before waste materials from industrial, commercial, and municipal operations are discharged into ground and surface waters of the state and into municipal sewerage systems. It is DOE's policy that no new wastes or wastewater will be disposed uncontrolled to the soil column. A monitoring system/plan is needed for this category of disposal. An SWDP is not required for discharges of pollutants into navigable waters already covered by an NPDES permit program.

EVALUATION: Not Applicable. The WFD Project does not plan to dispose any liquids to the soil column.

Approval of engineering reports, plans, and specifications and operating and maintenance manual WAC 173-240

Before construction or modification of those domestic or industrial wastewater facilities requiring Ecology wastewater discharge permits, engineering reports, plans, and specifications for the project must be submitted to and approved by Ecology. Operation and maintenance manuals must be submitted before construction is completed.

EVALUATION: Not Applicable. The WFD Project does not plan to discharge any wastewaters, other than small quantities to already permitted facilities.

\section{Underground Injection Control (UIC) Permit/Registration - WAC 173-218}

Authorization by Ecology of fluids injected through wells has been restricted to wells operational before February 29, 1984. New discharges of uncontaminated storm water and groundwater return flow, unaltered except for temperature from a ground water heat pump used for heating or cooling, are the only discharges that are not prohibited. These discharges must be registered with Ecology before construction.

EVALUATION: Not Applicable. The WFD Project does not plan to allow any of its structures to collect stormwater. The WFD-involved tank farms are all gravel-surfaced, with frequent monitoring for surface contamination, which is dispositioned immediately under existing procedures. 


\section{DOMESTIC WASTE WATER DISPOSAL}

\section{Septic System approvals/permits (<14,500 gpd design capacity) - WAC 246-272}

Plans and specifications for construction of a new sanitary sewer system or modification of an existing system shall be submitted and approved by the DOH before construction or entering into a contract for construction. Once the installation is complete, a professional engineer registered in Washington State must certify that the installation has been installed according to plans and specifications approved by the DOH. In addition, an operation and maintenance manual must be submitted to the DOH.

\section{Septic System approvals/permits (>14,500 gpd design capacity) - WAC 173-216; WAC 173-240}

Septic systems with design capacities greater than 14,500 gpd are governed by State Waste Discharge . Permits (WAC 173-216) and the engineering report, plan, and specification approval process described in WAC 173-240.

\section{Discharge Standards and Effluent Limitations for Domestic Waste Water Facilities - WAC 173-221}

Effluent from domestic wastewater treatment facilities, except subsurface septic tank systems with capacities less than 14,500 gallons per day, must meet the discharge standards established in this regulation.

Note: The $\mathrm{DOH}$ has taken the following position regarding modification or expansion of a drainfield located in the area of a known subsurface chemical hazard that could potentially cause the plume to harm groundwater: No modification or expansion will be allowed, consistent with regulations established for larger on-site sewage systems, preliminary report requirements (WAC 246-272-080).

EVALUATION: Not applicable. The WFD-involved tank farms each have a designated change facility, with operational septic systems, permitted under full-use assumptions. No increase in these facilities is planned, and the operational staff needed to perform both installation of new in-tank systems/equipment will not over-stress the facility's capacities.

\section{Pretreatment Permit - 40 CFR 403}

New wastewater discharges to the City's sewage treatment plant may be required to submit permit applications to the City of Richland before discharging sewage, industrial waste, or other waste. Whether a permit application is needed depends on whether the activity is considered a Significant Industrial Discharge by the City or fits a national pretreatment category.

EVALUATION: Not Applicable.

\section{Operator Certification - WAC 173-230}

Every operator in responsible charge of a domestic wastewater treatment plant is required to be certified at a level equal to or higher than the classification rating of the treatment plant being operated. Septic systems are excluded from requiring certified operators. 
EVALUATION: Not Applicable.

\section{SURFACE WASTE WATER DISPOSAL}

\section{NPDES Permit - 40 CFR 122}

Any discharge of pollutants to waters of the United States is required to have an NPDES permit before operation. The regulatory agency responsible for issuance of this permit is the EPA.

\section{Ecology Certification of an EPA NPDES Permit - 40 CFR 121}

EPA may not issue an NPDES permit until a certification is granted or waived by Ecology. Ecology must certify that conditions necessary to ensure compliance with applicable federal and state water quality standards.

EVALUATION: Not Applicable. The WFD Project does not include any NPDES discharges.

\section{Storm Water Discharge under EPA NPDES General Permit - 57 Federal Register 175,} September 9, 1992

The Hanford Site is covered under two storm water permits. Permit WA-R-00-000F covers storm water runoff for the Hanford Site as a whole. Permit WA-R-10-000F covers storm water runoff from construction projects. If there is a potential for storm water to reach the river from construction activities, an NOI for authorization under the EPA general permit and a storm water disposal permitting plan (SWDPP) must be in place at least two days before discharge from new construction sites (those begun after October 1, 1992).

EVALUATION: Not Applicable. The WFD Project does not any general storm water discharges. Should individual supporting projects identify such discharges during final design, the issue will be evaluated and permitting developed.

\section{U.S. Army Corps of Engineers (USACE) Permit - 33 CFR 325}

Discharging dredge and fill material into waters of the United States requires a permit from the USACE, before initiating the activity.

\section{Wild and Scenic Rivers: Section 10 Permit - 33 CFR 322}

Permits are required before the construction of structures and the performance of other activities in or adjacent to navigable waters. Certain activities are covered by nationwide permits rather than individual Section 10 permits. However, any work in an area designated as a "study river" for possible inclusion in the Wild and Scenic River System, such as the Hanford Reach, must obtain an individual Section 10 permit. 


\section{Nationwide Waterway Permits - 33 CFR 330}

Nationwide Permits are general permits issued by the USACE designed to regulate with little, if any, delay or documentation, certain waterway activities having minimal impacts. These permits are not applicable for projects within a Wild and Scenic River study area.

EVALUATION: Not Applicable. The WFD Project does not plan any such activity.

\section{Hydraulic Projects Permit - WAC 220-110}

Any construction or other work that will change the natural flow of a river, including the addition of treated effluent waste water that will increase the natural flow, is required to obtain a hydraulic project approval from Washington State Department of Fisheries.

\section{Shoreline Development Permit - WAC 173-14 to -20}

A permit for developing the shoreline is required before construction for shorelines not federally owned, but under lease, easement, license, or other similar federal property rights short of fee ownership.

\section{Aquatic Lands Lease - WAC 332-30}

Aquatic land activities that interfere with the general public's use of state-owned tidelands, shorelands, and beds of navigable waters, require authorization before construction from the State of Washington Department of Natural Resources by way of agreement, lease, permit, or other instrument(s).

EVALUATION: Not Applicable. The WFD Project does not plan any such activity.

\section{Hanford Reach Study Act Notification - PL 100-605}

Proposed construction within one-quarter mile of the Columbia River shoreline inside the Hanford Reach Area is subject to consultation and coordination with the National Park Service.

EVALUATION: Not Applicable.

\section{Water Quality Modification Approval - WAC 173-201}

A permit, directive, or order, as appropriate, must be obtained from Ecology before undertaking an activity that will temporarily reduce water quality below the criteria and classifications established for the stream.

EVALUATION: Not Applicable. 


\section{Categorical Standards}

Effluent Guideline and Standards - 40 CFR 405 to 471

These regulations list industry categories associated with the NPDES permit program. The regulations prescribe effluent limitation guidelines for existing sources, standards of performance for new sources, and pretreatment standards for new and existing sources.

EVALUATION: To Be Determined. It is assumed that since no NPDES discharges are planned by the WFD Project, that this criterion will not apply. However, the individual supporting projects should perform a compliance review during final design, and that review may identify certain small quantity liquid discharges, which may need to be designated. This may be an issue for supporting project W-320, which may have either chiller condensate or liquid effluent to route to a disposal area. The categorical standards, may then apply as ARARs.

\section{DRINKING WATER SUPPLY}

\section{Approval of Engineering Reports, Plans and Specifications - WAC 246-290}

Approval of engineering reports, plans, and specifications for a drinking water supply system is required before construction.

\section{Drinking Water System Identification - WAC 246-290}

New drinking water systems must obtain an identification number from the DOH before operation.

\section{Drinking Water System Operator Certification - WAC 246-292}

Operators in direct responsible charge of certain public water systems must be examined and certified for their competency on state requirements and standards before operating the system. Systems requiring certified operators include systems with 100 services at any one time; or systems serving 25 or more persons where the water is supplied from a stream, lake, or other surface water source and the systems are required by law to use a water filtration system.

EVALUATION: To Be Determined. The WFD Project will use existing Hanford drinking water systems. Modification of existing sanitary water lines to existing use areas is assumed to be within normal maintenance activity, and should not require State approval. Expansion of the water delivery system to new using areas, plus the Privatization Initiative contractors may require State review/approvals. This issue will be determined by supporting project W-519 during preliminary design.

Contact R. D. Potter (373-9315) for data identification needs.

Contact J. S. Hill (372-1617) for assistance with water delivery issues. 


\section{HIGH-LEVEL WASTE}

\section{Reprocessing of Spent Nuclear Fuel - Atomic Energy Act, DOE Order 5820.2A, 10 CFR 962 Design Criteria - DOE Order 6430.1A}

High-level Waste (HLW) is a source designation, for the first stage of waste separated from processing irradiated nuclear fuel and other similar materials. High level waste must not be confused with high-activity waste; handling/design requirements apply differently. Requirements for HLW management, handling, packaging, treatment, transport, and storage are summarized in DOE Order $5820.2 \mathrm{~A}$, and its associated references. Facilities whose primary function is that of management of HLW must be designed in accordance with special requirements in DOE Order 6430.1A and its references. Very small quantities of HLW may be exempted from some of these requirements, through a "de minimus" exemption. In general, HLW will have both a radioactive component (controlled by the Atomic Energy Act) and a hazardous material component (controlled by RCRA). Congress (10 CFR 962) decided that both sets of controls must be applied to HLW projects.

DOE Policy requires that all HLW will be safely stored, treated, and disposed of in accordance with all applicable requirements, particularly those of the EPA (40 CFR 191) and the applicable State(s).

Most HLW is also classified as transuranic (TRU) waste if the wasteform exceeds the activity level of 100 nanocurie/gram from TRU elements, at the time of final stage processing, and before dilution for pumping. Most TRU processes must also meet criticality safety controls, but these are not part of the environmental compliance issues. Facility permits will incorporate all applicable compliance criteria.

Treatment, storage and disposal processes must meet applicable standards for clean air, clean water, and protection of the environment just as if they were general RCRA controlled wastes. Facilities which have formerly treated and/or stored HLW may be decontaminated under either RCRA or CERCLA authority. A special review of environmental requirements for the $D \& D$, plus final closure must be made in a closure plan, which is outside the scope of this checklist.

EVALUATION: To Be Determined. The WFD Project may include retrieval, in-tank processing, separation of HLW, LLW and LAW, using different methods. The quantities of each class are currently not well defined. Each individual project should make a definition effort during conceptual design, and use the results as the bases for further compliance strategizing.

It may well be simpler to design all new receptor/transferal systems to handle HLW, unless specifically eliminated by the analysis.

Contact R. D. Potter (373-9315) for project data identification needs. Contact D. W. Fritz (372-2206) for guidance on defining High-Level Waste issues.

\section{SOLID WASTE}

\section{Solid Waste Handling Facility Permit - WAC 173-304 Pollution Prevention/Waste Minimization}

Solid waste TSD sites or facilities (i.e., landfills, land spreading, piles, surface impoundments, and recycling facilities) must obtain approval from Ecology via the comprehensive solid waste plan, and from the juris- 
dictional county health department before construction. Benton and Franklin County Health Departments will be notified, since they may also provide emergency response capability.

All facilities are covered by the Hanford Site Waste Minimization and Pollution Prevention program plan (DOE/RL-91-31). New facilities must also develop a Pollution Prevention/Waste Minimization strategy, and incorporate guidelines from HNF-PRO 462 into any operations prior to startup. Legislative drivers are in the referenced procedure.

EVALUATION: It is assumed that the only solid waste that WFD handles will be that of a secondary generation nature ( $\mathrm{eg}$, retrieved items from the tanks, decontamination of same, personal protective equipment, etc). A compliance review for waste-minimization/pollution prevention should be made by the individual supporting projects during final design, to identify issues and evaluate methods to. minimize the impacts.

Contact R. D. Potter (373-9315) for WFD general environmental project support. Contact Ms. D. S. Merry (376-9773) for assistance with waste minimization issues.

\section{DANGEROUS WASTE}

\section{Dangerous Waste Permit - WAC 173-303; 40 CFR 264, 265, 270 \\ Resource Conservation and Recovery Act (RCRA) Part A - WAC 173-303-805, Part B - WAC 173-303-806}

Facilities that treat, store, or dispose (TSD) of regulated dangerous waste must obtain the necessary permits. Whether a waste is a regulated dangerous waste must be determined in accordance with WAC 173-303-070 designation procedures. Existing Hanford Facility TSD units are in process of obtaining permits in accordance with schedules and procedures identified in the Tri-Party Agreement.

New Hanford Facility TSD units that are not identified in the Tri-Party Agreement will require development of a permitting plan to detail the strategies and schedules to be used for developing the necessary dangerous waste permits. This plan must be developed early in the project development phase, strategies and schedules to be used for developing the necessary dangerous waste permits for new TSD units will need to be discussed with the appropriate regulatory agencies to gain their concurrence.

EVALUATION: Each of the WFD-involved tank farms is currently included in the Hanford Dangerous Waste Permit Part A application documentation. Separate data are provided with the permit for the SSTs, DST, and Aging Waste Facility. Intra-farm piping is incorporated as part of the tanks' ancillary equipment. Inter-farm piping may need to be evaluated, to ensure suitable regulatory compliance.

It is recommended that the WFD and its supporting projects perform a review for compliance and ensure that the Hanford Dangerous Waste Permit suitably covers all proposed activity.

Contact R. D.Potter (373-9315) for WFD general environmental support.

Contact W. E. Toebe (372-2359) for dangerous waste requirement issues.

Contact C. H. Mulkey (373-0956) for data identification needs.

Contact R. H. Engelmann (376-7485) for permit modification issues. 


\section{Notice Of Intent (NOI) - WAC 173-303-281}

A NOI is required for proposed RCRA TSD facilities or expansion at an existing RCRA facility. Expansion includes enlargement of land surface area, the addition of new dangerous waste processes, or an increase in overall design capacity. The NOI contains preliminary information concerning the proposed facility and/or expansion. The NOI requires a general process description, operating capacities, waste type, a topographic map, and a statement of environmental conditions, which could include a SEPA environmental checklist or a SEPA adoption letter.

EVALUATION: To Be Determined. Existing facilities already under interim status, with a RCRA Part A, may be allowed to proceed by filing a revision to the Part A, or to the next submittal/revision of the Part $B$. New facilities should be individually evaluated for NOI needs.

If it is determined that a NOI will need to be prepared for the WFD as a whole, or a supporting project, it would need to be submitted to the public (public reading rooms) and Ecology, in accordance with WAC 173-303-281. A notification is published in a local daily newspaper for 14 consecutive days. The entire NOI process normally requires approximately 11 months to prepare and submit.

Contact R. D. Potter (373-9315) for WFD general environmental project support. Contact C. H. Mulkey (373-0956) for data identification needs. Contact R. H. Engelmann (376-7485) for assistance in preparing the NOI.

Non-Standard Methods, RD\&D Permit, Modification and Waivers - WAC 173-303-500 to 607, 809 \& 830.

The Research, Development \& Demonstration permit is intended to provide flexibility for TSD units that propose to use an innovative and experimental technology for RCRA wastes. The RD\&D permit is similar to the Part $\mathrm{B}$, and is prepared according to WAC 173-303-809, if the proposed process is not covered in WAC 173-303 sections 500-670 (inclusive).

Permit modifications and waivers from existing RCRA TSD operations are allowed. Modification/waiver applications are covered in WAC 173-303-830, and HNF-PRO-454, for RCRA waste handling guidelines.

EVALUATION: To Be Determined. It is assumed that the WFD project will not use any unproven technologies or methods; an evaluation for waivers should be made by each of the supporting projects. It is expected that modifications to existing facilities will be made; the impacts of which will need to be quantified, before seeking approvals.

However, physical mixing of some tank wastes may release threshold values of flammable gases. This has been an issue for supporting project W-151. Environmental requirements and strategy for this and similar projects will be identified during final design, by each supporting project.

Contact R. D. Potter (373-9315) for WFD general environmental project support. Contact W. E. Toebe at (372-2359) for RCRA Waste Regulation interpretations.

Contact F. A. Ruck III at 376-8676 for RCRA. Permit Modification issues.

Contact R. H. Engelmann (376-7485) for permit application assistance. 


\section{UNDERGROUND STORAGE TANKS}

\section{Underground Storage Tank (UST) Permit - WAC 173-360}

After July 1, 1991, no UST system, as defined in WAC 173-360 (miscellaneous underground tanks), shall be operated without a valid permit from the regulatory agency.

EVALUATION: To be determined. Chemical reagents and petroleum products may be stored in USTs to support WFD. This will be evaluated for each WFD program activity.

Contact R. D. Potter (373-9315) for WFD general environmental project support. 
HNF-2401, Rev. 0

\section{APPENDIX B}

\section{SUMMARY OF INFORMATION AND DATA NEEDS}


HNF-2401, Rev. 0

This page intentionally left blank. 
HNF-2401, Rev. 0

\section{SUMMARY OF INFORMATION AND DATA NEEDS}

The following is a summary of information needed to meet the regulatory requirements and documents discussed in this permitting plan.

\section{NEPA/SEPA}

- Purpose and Need for Action

- Why action is needed now

- How this action relates to other actions.

- Design Components

- Conceptual design or equivalent information to assist in NEPA evaluation of level of NEPA required by critical decision 1

- 30\% design information to assist in a NEPA determination (e.g., ROD, FONSI, or CX) supplement analysis determination for adequacy of existing EIS by critical decision 2 .

- Alternatives Considered

- Do nothing different from current storage

- Pick a disposal method that does not require intermediate storage

- Use a different type or form of interim waste storage

- Use a different location for interim storage.

- Environments and Resources Affected

- Geological, aquatic, atmospheric, biological, cultural, socioeconomic, terrestrial, visual, audio, and natural environments

- Transportation.

- Environmental Consequences

- Possible consequences to environments previously listed

- Anticipated health effects from routine and non-routine operations, including accidents

- Possibility of disproportionate impacts on minority group(s) identified. 
HNF-2401, Rev. 0

- Statutory and Regulatory Requirements

- These relate to Resource Conservation and Recovery Act (RCRA) of 1976 and other regulatory permitting requirements addressed in other sections of this permitting plan.

- Any CERCLA documents that might be relevant to the proposed activity.

- Additional Supporting Documents

- Additional documents related to safety, engineering, and project planning

- Waste evaluation documents that might be helpful in the NEPA evaluation and documentation process.

Preparation of appropriate NEPA documentation requires data on natural, biological, or cultural resources used or impacted by the alternatives considered; socioeconomics of the region; land use, both current and future; visual resources impacted; noise and transportation impacts from construction, operation, and decommissioning; and hazardous or toxic substances used or potentially released into the environment.

\section{RCRA}

\section{Notice of Intent and Part A}

The following information is required under WAC 173-303-281, -282 and -805 when submitting an NOI for expansion under interim status:

- Facility description

- Explanation of expansion

- Siting criteria

- 10-year summary of formal Notice of Violation and/or Notice of Penalty

- Demonstrated need for expansion

- Comparison of proposed expansion to overall unit capacity

- A SEPA environmental checklist or SEPA Adoption Notice

- 150-day public review of NOI before submittal of Part A, Form 3

- A Tri-Party Agreement milestone for submittal of the initial Part B

- Negotiation with Ecology for submittal of the final status.Part B into the Hanford Facility RCRA Permit. 
HNF-2401, Rev. 0

\section{Part B}

The following are general requirements (WAC 173-303-806) for the Part B. Additional facility information would be provided for information.

- A general description of the facility

- Chemical, biological, and physical analyses of the dangerous waste and hazardous debris to be managed at the facility. At a minimum, these analyses must contain all the information that must be known to treat, store, or dispose of the waste properly in accordance with WAC 173-303-600

- A copy of the waste analysis plan required by WAC $173-303-300(5)$

- A description of security procedures and equipment required by WAC 173-303-310, or a justification demonstrating the reasons for requesting a waiver of this requirement

- A copy of the general inspection schedule required by WAC 173-303-320(2) and 173-303-630(6)

- A description of the procedures used to comply with the preparedness and prevention requirements of WAC 173-303-340, or a justification of any request for a waiver(s) from these requirements

- A copy of the contingency plan required by WAC 173-303-350

- A description of the procedures, structures, or equipment used at the facility to:

- Prevent hazards and contain spills in unloading/loading operations

- Prevent run-off from dangerous waste handling areas to other areas of the facility or environment, or to prevent flooding

- Prevent contamination of water supplies

- Mitigate effects of equipment failure and power outages

- Prevent undue exposure of personnel to dangerous waste

- Prevent releases to the atmosphere.

- Vehicular traffic pattern, estimated volume, and control

- Seismic risk consideration. The owner or operator must identify the seismic risk zone in which the facility is intended to be located. It must be demonstrated that the facility is designed to resist seismic ground motion and that the design is sufficient to withstand the maximum horizontal acceleration of a design earthquake specified in the demonstration

- An outline of both the introductory and continuing training programs that prepare persons to operate or maintain the TSD facility in a safe manner as required to demonstrate compliance 
HNF-2401, Rev. 0

with WAC 173-303-330. A brief description of how training will be designed to meet actual job tasks in accordance with the requirements in WAC 173-303-330(1)(d)

- A copy of the closure plan required by WAC 173-303-610(3) and 173-303-630(10)

- A topographic map meeting all applicable requirements in WAC 173-303-806(4)(a)(xviii).

\section{Specific Container Requirements}

- A description of the containment system to demonstrate compliance with WAC 173-303-630(7), showing at least the following:

- Basic design parameters, dimensions, and materials of construction, including allowance for a 25-year, 24-hour storm

- How the design promotes positive drainage control or how containers are kept from contact with standing liquids in the containment system

- Capacity of the containment system relative to the volume of the largest container to be stored

- Provisions for preventing or managing run-on

- How accumulated liquids can be analyzed and removed to prevent overflow

- A description of the building or other protective covering for extremely hazardous waste containers.

- For storage areas that store containers holding waste that do not contain free liquids, a demonstration of compliance with WAC 173-303-630(7)(c), including the following:

- Test procedures and results or other documentation or information to show that the waste does not contain free liquids

- A description of how the storage area is designed or operated to drain and remove liquids or how containers are kept from contact with standing liquids.

- A description of procedures for labeling containers.

\section{Radiation Protection}

- Background radiation levels at the project site and in surrounding areas, including onsite and offsite

- Radionuclides present in flora, fauna, soil, wildlife, water, vadose and groundwater, agriculture products, and, in some circumstances, members of the public. 
HNF-2401, Rev, 0

\section{MUSCELLANEOUS ASSESSMENTS, PERMITS, AND APPROVALS}

\section{Cultural/Ecological Resource Review}

A Cultural/Ecological Resource Review (CERR) should be obtained from PNNL prior to initiating an surface-disturbing activities onsite, renovating/repairing/demolishing facilities, or prior to excessing land.

- Submit request form with a map identify the area to be disturbed, buildings, or tanks in question.

\section{Site Location}

New facilities must receive a site location review as part of a Hanford Site best management practice. Information needed to support the review includes:

- A location map of area, buildings, tanks, piping etc.

- Design reports and siting descriptions.

\section{Excavation Permit}

An Excavation Permit is required before initiating surface-disturbing onsite activities.

- Identify need for excavation

- Obtain composite map of intended excavation, including excavation boundaries and reference location

- If CERR is not waived, complete and submit a CERR

- Determine proximity of excavation to existing waste sites by using ArcView information

- Determine if NEPA documentation required through use of NEPA Screening Form.

\section{American Indian Tribal Government Agreements}

- If CERR is not waived, complete and submit a CERR.

\section{Endangered Species Act}

- If CERR is not waived, complete and submit a CERR.

\section{Pre-operational Monitoring}

A pre-operational environmental study shall be conducted before startup of a site, facility, or process that has potential for significant adverse environmental impact and should begin not less than one year before startup. This study precedes conceptual design and includes the following information needs:

- data acquired in the site selection process

- excavation permit data . 
HNF-2401, Rev. 0

This page intentionally left blank. 
HNF-2401, Rev. 0

APPENDIX C

WASTE FEED DELIVERY PERMITTING SCHEDULE 
HNF-2401, Rev. 0

The information provided in this appendix currently reflects preliminary schedules that might be incurred by the projects linked to the WFD system. As project-specific environmental permitting costs and schedules are identified and provided to WFD, it is anticipated that they will be consolidated to reflect WFD system programmatic costs and schedules. 
HNF-2401, Rev. 0

This page intentionally left blank. 


\begin{tabular}{|c|c|c|c|c|c|}
\hline$\cdots$ & \multicolumn{5}{|c|}{ DISTRIBUTION SHEET } \\
\hline \multirow{2}{*}{$\begin{array}{l}\text { To } \\
\text { Distribution }\end{array}$} & \multirow{2}{*}{\multicolumn{3}{|c|}{$\begin{array}{l}\text { From } \\
\text { Waste Feed Delivery Program }\end{array}$}} & \multicolumn{2}{|c|}{ Page 1 of 1} \\
\hline & & & & \multicolumn{2}{|c|}{$\begin{array}{ll}\text { Page } 1 \text { of } 1 \\
\text { Date } 06 / 09 / 98\end{array}$} \\
\hline \multicolumn{4}{|c|}{ Project Title/Work Order } & \multicolumn{2}{|c|}{ EDT No. 608764} \\
\hline \multicolumn{4}{|c|}{$\begin{array}{l}\text { Waste Feed Delivery Environmental Permits and Approvals Plan } \\
\text { (HNF-2401) }\end{array}$} & \multicolumn{2}{|l|}{ ECN No. } \\
\hline Name & MSIN & $\begin{array}{l}\text { Text } \\
\text { With All } \\
\text { Attach. }\end{array}$ & Text Only & $\begin{array}{l}\text { Attach./ } \\
\text { Appendix } \\
\text { Only }\end{array}$ & $\begin{array}{l}\text { EDT/ECN } \\
\text { Only }\end{array}$ \\
\hline
\end{tabular}

T. W. Bohan

K. A. Boes

H. L. Boston

D. J. Carrel1

G. D. Cummins

M. L. Defffenbaugh

B. G. Erlandson

J. S. Garfield

C. J. Grando

D. M. Hammond

R. P. Marshall

E. E. Mayer

C. H. Mulkey

I. G. Papp

R. D. Potter

R. W. Powel]

R. J. Parazin

C. A. Rieck

R. W. Root

W. T. Thompson

R. L. Treat

J. E. Van Beek

R. D. Wojtasek

- Central Files

TWR DIMC

S7 -04

R3-25

G3-21

R1-51

H6-26

H6-37

R1-51

H5-49

R1-51

R1-44

H5- 03

R2-50

R1-51

H5- 49

H5- 49

H5-03

H5-49

$52-48$

H6- 12

G3-21

H5- 03

S2-48

G3-21

B1-07

H6-15 